University of South Florida

DIGITAL COMMONS

@ UNIVERSITY OF SOUTH FLORIDA
Digital Commons @ University of

South Florida

$9-1-2003$

\title{
Quantifying the Business Benefits of TDM
}

CUTR

Follow this and additional works at: https://digitalcommons.usf.edu/cutr_nctr

\section{Scholar Commons Citation}

CUTR, "Quantifying the Business Benefits of TDM" (2003). Research Reports. 203.

https://digitalcommons.usf.edu/cutr_nctr/203

This Technical Report is brought to you for free and open access by the National Center for Transit Research (NCTR) Archive (2000-2020) at Digital Commons @ University of South Florida. It has been accepted for inclusion in Research Reports by an authorized administrator of Digital Commons @ University of South Florida. For more information, please contact digitalcommons@usf.edu. 


\title{
Quantifying the Business Benefits of TDM
}

\author{
Prepared by: \\ Philip L. Winters \\ TDM Program Director \\ Sara J. Hendricks \\ Senior Research Associate \\ National Center for Transit Research \\ Center for Urban Transportation Research \\ College of Engineering \\ University of South Florida \\ 4202 E. Fowler Avenue, CUT 100 \\ Tampa, Florida 33620-3120 \\ 813.974.3120 \\ http://www.nctr.usf.edu/ \\ Project Manager \\ Elizabeth Stutts, FDOT \\ Florida Department of Transportation \\ 605 Suwannee Street \\ Tallahassee, Florida 32399-0450 \\ FDOT Contract Number BC137-23 \\ Research and Special Program Administration \\ U.S. Department of Transportation \\ RSPA/DIR-1, Room 8417 \\ 4007 th Street, SW \\ Washington, DC 20590 \\ http://www.rspa.dot.gov/
}

The opinions, findings, and recommendations expressed in this publication are those of the authors and not necessarily those of the Florida Department of Transportation or the U.S. Department of Transportation.

The document was prepared in cooperation with the State of Florida Department of Transportation and the U.S. Department of Transportation. 


\section{Table of Contents}

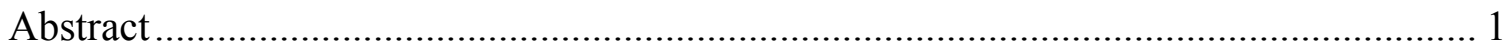

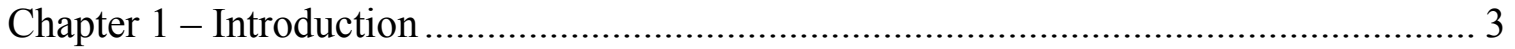

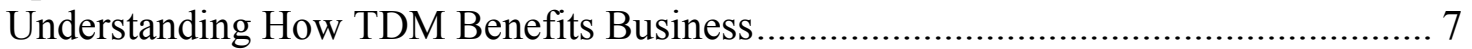

Factors Contributing to Business Profitability........................................................ 9

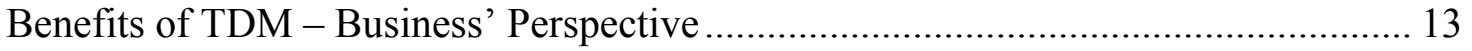

Approaches to Assessing the Impacts of Business Benefits ..................................... 19

Chapter 2 - Existing Tools for Calculating Costs and Benefits ..................................... 21

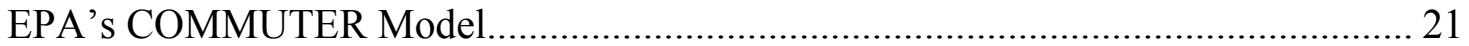

Business Benefits Calculator ................................................................................. 27

Commuter Choice Decision Support System ......................................................... 37

CUTR_AVR - Worksite Trip Reduction Model ........................................................ 39

Chapter 3 Methodologies for Quantifying Select Business Benefits............................. 42

Business Benefit: Reduction in Costs of Turnover...................................................... 42

Business Benefit: Reducing the Costs of Absenteeism ............................................ 55

Business Benefit: Reducing the Cost of Parking ................................................ 59

Business Benefit: Employer-Provided Commuter Benefits ..................................... 63

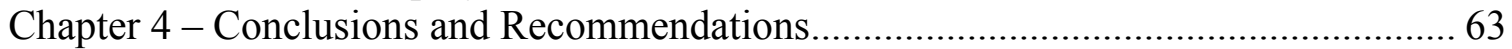

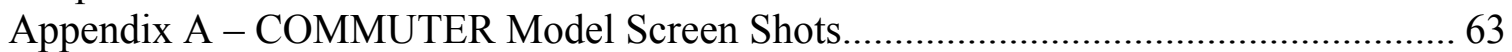




\section{List of Tables}

Table 1. Typology of Congestion Impacts on Business.

Table 2. Regulation XV Cost Survey. 6

Table 3. Distribution of Annual Revenue and SG\&A Costs During the Period 1979 1998 (millions of dollars). $\quad 11$

Table 4. COMMUTER Model Inputs. $\quad 22$

Table 5. TDM Program Options.

Table 6. Employer Program Support Levels.

Table 7. Vehicle Trip Reduction - Scenario: Company with 200 employees and existing vehicle trip rate of 82.7 vehicles per 100 employees $\quad 40$

Table 8. Employer Benefits - 1999 and 2000. 43

Table 9. Flexible Work Place Trends for Medium and Large Private Employers. 45

Table 10. Consequences of Turnover for Individuals.

Table 11. Departing Employee Inefficiency. 49

Table 12. Incoming Employee Inefficiency.

Table 13. Costs of Turnover - Inefficiency of the Departing Employee. 5

Table 14. Costs of Turnover - Inefficiency of the Position Being Filled While Vacant. $\quad \mathbf{5 0}$

Table 15. Costs of Turnover - Out-of-Pocket Processing Hiring Costs. 51

Table 16. Costs of Turnover - Human Resource Department Processing Costs. 51

Table 17. Costs of Turnover - Human Resource Department Processing Costs. 51

Table 18. Costs of Turnover - Relocation Costs.

Table 19. Costs of Turnover - Inefficiency of the Incoming Employee. 52

Table 20. Costs of Turnover - Inefficiency of Those Closely Associated with Incoming Employee. $\quad \mathbf{5 2}$

Table 21. Total Costs of Turnover.

Table 22. Employee Retention Required Per $\$ 100,000$ Investment with a 12 month Payback. $\quad 53$

Table 23. Absences From Work Of Employed Full-Time Wage And Salary Workers By Occupation (2001). $\quad 55$

Table 24. Estimating the Cost of Absenteeism.

Table 25. Maximum Investment Per 100 Employees Allowed to Reduce Cost of Employee Absenteeism To Reach Goal (with a 12 month return on investment).

Table 26. Employer-Provided Commute Benefits.

Table 27. Reasons for Providing a Given Commute Benefit.

Table 28. Construction Cost per Parking Space. $\quad 61$

Table 29. Cost of Parking - Surface Lot Scenarios.

Table 30. Cost of Parking - Above Grade Structure Scenarios.

Table 31. Subsidized Commuting Trends for Medium and Large Private

$\begin{array}{ll}\text { Employers. } & 63\end{array}$

Table 32. Qualified Transportation Fringe Benefit Example - Assumptions. 63

Table 33. Comparison of Pre-Tax Qualified Transportation Fringe Benefit Plan. 63

Table 34. 2003 Tax Tables - Single Person (including head of household). 63

Table 35. 2003 Tax Tables - Married Person. 63 
Table 36. Increase in Spendable Income to Employee with Pre-Tax Benefit - Single Person.

Table 37. Increase in Spendable Income to Employee with Pre-Tax Benefit Married Person.

Table 38. Total Estimated Annual Payroll Tax Savings to Employer. 


\section{List of Figures}

Figure 1. Interrelations of Prices, Products, and Resources to Profit. 9

Figure 2. Business Benefits Calculator Welcome Screen. 28

Figure 3. Business Benefits Calculator Input Employer Information Screen. 28

Figure 4. Business Benefits Calculator Input Employer Information Screen. 29

Figure 5. Business Benefits Calculator - Select Benefits Screen. 31

Figure 6. Business Benefits Calculator - Select Benefits Screen (cont.). 31

Figure 7. Business Benefits Calculator - Participation Estimation Screen. 32

Figure 8. Business Benefits Calculator - Results Summary Screen. 33

Figure 9. Business Benefits Calculator Input Employer Information Screen. $\quad 34$

Figure 10. Business Benefits Calculator Input Employer Information Screen. 34

Figure 11. Commuter Model Opening Screen. $\quad 63$

Figure 12. Commuter Model - Scenario Information Screen. 63

Figure 13. Commuter Model - Scenario Information Screen (cont.). 63

Figure 14. Commuter Model - Scenario Information Screen (cont.). 63

Figure 15. Commuter Model - Local Data Screen. $\quad 63$

Figure 16. Commuter Model - Local Data Screen (cont.). $\quad 63$

Figure 17. Commuter Model - Site Access and Transit Service Improvements

Screen.

Figure 18. Commuter Model - Site Access and Transit Service Improvements Screen (cont.).

Figure 19. Commuter Model - Site Access and Transit Service Improvements Screen (cont.).

Figure 20. Commuter Model - Financial Incentives and Parking Screen.

Figure 21. Commuter Model - Employer Support Programs for Alternative Modes

- Site Specific Analysis Screen.

Figure 22. Commuter Model - Employer Support Programs for Alternative Modes

- Site Specific Analysis Screen.

Figure 23. Commuter Model - Alternative Work Schedules Screen. 63

Figure 24. Commuter Model - Alternative Work Schedules Screen. 63

Figure 25. Commuter Model - Fleet Emissions Information Screen. 63

Figure 26. Commuter Model - Fleet Emissions Information Screen (cont.). $\quad 63$

Figure 27. Commuter Model - Fleet Emissions Information Screen (cont.). $\quad 63$

Figure 28. Commuter Model - Other Emissions-Related Data Screen. 63

Figure 29. Commuter Model - Other Emissions-Related Data Screen (cont.). 63

Figure 30. Commuter Model - Other Emissions-Related Data Screen (cont.). $\quad 63$

Figure 31. Commuter Model - Results Screen. $\quad 63$

Figure 32. Commuter Model - Results Screen (cont.). $\quad 63$ 


\title{
Quantifying the Business Benefits of TDM
}

\begin{abstract}
Transportation demand management (TDM) is more than carpooling. It is a set of strategies that fosters increased efficiency of the transportation system by influencing travel behavior by mode, time, frequency, trip length, cost or route. Many TDM strategies encourage the use of alternatives to driving alone to help lessen congestion and air pollution. The effectiveness of these efforts depends on employer cooperation and policies supporting these strategies. Employees' use of transit depends on the compatibility of the employer work hour policies and attendance policies such as flextime with transit schedules. The ability of employees to take advantage of advanced traveler information systems to alter arrival and departure times to avoid congested periods depends on those same employer policies. Employer work-life friendly programs such as compressed workweek programs and telework reduce traffic and parking demands. Employer parking policies determine the availability and price of parking that influence mode choice by employees. The provision of bike and locker facilities by employers can make the difference between someone choosing to drive or use a non-motorized method.

Public transportation professionals have long believed that TDM provides a variety of benefits to employers. Telework programs can improve productivity, enhance recruitment and retention of employees, and reduce absenteeism. Compressed work week programs enable the employer to expand coverage to enhance customer service. Employers allowing employees to pay for transit passes and parking as a pre-tax benefit save payroll taxes.
\end{abstract}

The TDM industry must largely depend on empirical evidence of these TDM strategies implemented by employers. Most of the tool sets available to assess the impacts of TDM programs have focused on the transportation and air quality benefits. These public benefits may have little relevance for most employers unless they were subject to a trip reduction mandate. Ironically, TDM programs target employers to carry out their missions. Therefore, the quantitative evidence of benefits that accrue directly to businesses from a wide range of programs could offer a strong motivation for employers to begin, continue, and/or expand travel alternatives support activities.

The goal of this project was to identify the key business benefits of TDM and provide techniques for quantifying those benefits. This information should enhance the transportation professions understanding of TDM's value to business. This increase in awareness, in turn, should allow agencies to improve levels of employer participation in TDM and other transportation programs and thus provide reductions in congestion and air pollution for Florida and other states. From this point, a subsequent step for future research is the enhancement of existing tools (such as a custom-designed software application) to assist employers in assessing the costs and potential business benefits of implementing TDM programs

Conclusions and Recommendations 
The review of the efforts to quantify business benefits by employers and agencies points to several clear conclusions and recommendations: (1) Increase public sector research and technical assistance efforts to evaluate employer TDM programs for the impacts on business, not only transportation and emission impacts (2) Expand the tracking of employer-provided commute benefits to include parking by the Bureau of Labor Statistics and (3) integrate, update, and aggressively distribute the tools. 


\section{Chapter 1 - Introduction}

Many strategies to encourage the use of alternatives to driving alone to help lessen congestion and air pollution depend on employer cooperation and policies supporting these strategies. For example, employees' use of transit depends on the compatibility of the employer work hour policies with transit schedules and system reliability. The ability of employees to make use of 511 and other advanced traveler information systems to alter arrival and departure times to avoid congested periods depends on employer attendance policies such as flextime programs. Employer-provided work-life friendly programs such as compressed workweek programs and telework reduce vehicle trips as well as provide employers with a means for increasing productivity and reducing costs. Employer parking policies determine the availability and price of parking that influence mode choice by employees. The provision of bike and locker facilities by employers can make the difference between someone choosing to drive or use a non-motorized method.

Despite these direct connections between employer policies and efforts of the transportation demand management (TDM) community to reduce congestion, little is known of the consequences of congestion on business, specifically the magnitude of these costs and significance to profitability. ${ }^{1}$ A NCHRP study developed a typology of congestion impacts on business was developed to begin to understand these consequences.

\footnotetext{
${ }^{1}$ Congestion Impacts on Business and Strategies to Mitigate Them. NCHRP Research Results Digest Number 202.
} 
Table 1. Typology of Congestion Impacts on Business.

\begin{tabular}{|c|c|c|c|c|}
\hline & $\begin{array}{l}\text { Client Travel } \\
\text { to Obtain } \\
\text { Goods and } \\
\text { Services }\end{array}$ & Commuting & $\begin{array}{l}\text { Delivering } \\
\text { Goods and } \\
\text { Services }\end{array}$ & $\begin{array}{l}\text { Receiving } \\
\text { Goods and } \\
\text { Services }\end{array}$ \\
\hline $\begin{array}{l}\text { Direct } \\
\text { Traveler } \\
\text { Impacts }\end{array}$ & Not applicable & $\begin{array}{l}\text { Increased travel time } \\
\text { Increased vehicle } \\
\quad \text { operating costs } \\
\text { Change in travel hour } \\
\text { Change in trip } \\
\quad \text { frequency }\end{array}$ & Not applicable & Not applicable \\
\hline $\begin{array}{l}\text { Indirect } \\
\text { Traveler } \\
\text { Impacts }\end{array}$ & $\begin{array}{l}\text { Increased stress } \\
\text { and aggravation } \\
\text { Decreased quality } \\
\text { of life } \\
\text { Change in } \\
\text { destination }\end{array}$ & $\begin{array}{l}\text { Increased stress and } \\
\text { aggravation } \\
\text { Decreased quality of } \\
\text { life } \\
\text { Change in residence } \\
\text { Change in } \\
\text { Destination }\end{array}$ & $\begin{array}{l}\text { Increased } \\
\text { stress and } \\
\text { aggravation } \\
\text { Increased } \\
\text { pressure to } \\
\text { work harder } \\
\text { Decreased } \\
\text { quality of } \\
\text { life } \\
\end{array}$ & Not applicable \\
\hline $\begin{array}{l}\text { First-Order } \\
\text { Business } \\
\text { Consequences }\end{array}$ & Lost sales & $\begin{array}{l}\text { Recruitment and } \\
\text { retention problems } \\
\text { Tardiness or stress } \\
\text { concerns } \\
\text { Alternative work } \\
\text { schedule } \\
\text { complications } \\
\text { Trip reduction } \\
\text { requirements } \\
\end{array}$ & $\begin{array}{l}\text { Increased staff } \\
\text { and vehicles } \\
\text { Increased } \\
\text { inventory } \\
\text { New branch } \\
\text { locations }\end{array}$ & $\begin{array}{l}\text { Higher prices for } \\
\text { goods and } \\
\text { service } \\
\text { Disruptions to } \\
\text { operations }\end{array}$ \\
\hline $\begin{array}{l}\text { Second-Order } \\
\text { Business } \\
\text { Consequences }\end{array}$ & \multicolumn{4}{|c|}{$\begin{array}{l}\text { Change in prices or profits on sales to final consumers } \\
\text { Change in land use } \\
\text { Decline in business growth } \\
\text { Relocation of business } \\
\text { Decline in local spending } \\
\text { Loss in business economies of scale }\end{array}$} \\
\hline
\end{tabular}

The NCHRP study concluded that congestion costs are a relatively small portion of the total cost of doing business for many organizations. At the same time, the study points out that businesses do not explicitly account for the costs of congestion. However, it noted that companies do adapt business practices to minimize the consequences of congestion (e.g., flexible scheduling of deliveries, hiring of additional drivers of delivery vehicles). Simply stated, most companies do not internalize these costs. They do not measure and track the costs of congestion so alternatives such as transportation demand management (TDM) can be evaluated as directly influencing business profitability.

NCHRP study did note that employees adapt to traffic congestion by moving and/or adjusting work schedules. Such adapted behavior comes at a considerable cost to the 
employee and the company. The NCHRP report found that the direct costs of congestion and the indirect costs of congestion avoidance by employees such as residential relocation impose a substantial cost on business. The study suggests that strategies beyond providing additional capacity at critical bottlenecks should be considered to reduce the cost of urban congestion to business. Specifically, they noted the need for monitoring and communicating information about the system's performance. Businesses are adept at adjusting their operations to minimize the costs of congestion, especially when the patterns are understood and relatively predictable.

The staggering cost of congestion is not lost on the business community. According to the U.S. Chamber of Commerce, "The cost of road congestion to the U.S. economy was about $\$ 78$ billion in 1999, more than triple the $\$ 22$ billion cost in 1982."

While employers often agree that traffic congestion is a real problem, but they may not recognize the full range of potential consequences of congestion on their workforce. This view may mean they may fail to see the need for implementing TDM strategies to address those problems. For example, a study concerning marketing high occupancy vehicle (HOV) lanes along the I-95 corridor in South Florida found a disconnect between the traffic congestion problem as perceived by businesses and the affect on their organization. About 85 percent of surveyed employers strongly agreed that traffic congestion was a serious problem; but only 20 percent strongly agreed that traffic congestion could make their employees late for work. ${ }^{2}$

Approaches to force employers to assume more responsibility for congestion and its consequences via regulations have evolved. In most markets, regulatory mandates on large employers in severe or extreme ozone nonattainment areas have given way to market-based solutions or emphasis on sound business practices for addressing their needs. In addition to the general move toward deregulation, the issue of the cost to employers for carrying out these mandates helped push deregulation. The omission of benefits is akin to evaluating a company's performance on its expenses but not considering its revenues or profitability.

Though not extensive, TDM research has focused on the costs of TDM to business while largely ignoring the savings that accrue from those investments. An often-cited study by Ernst and Young, Regulation XV Cost Survey, attempted to quantify the employer's costs for complying with the Regulation XV trip reduction ordinance (now referred to by as Rule 2202). The consultants prepared the study for the South Coast Air Quality Management District (SCAQMD) to estimate the annual compliance costs incurred by employers and the change in employee commute trips associated with those costs.

Ernst and Young sent the survey to each of the 5,763 regulated private and public sector sites in the SCAQMD's four county area and achieved a 19 percent response rate. Employers were directed to split their costs into four areas: training of the Employee Transportation Coordinator, plan preparation and approval, plan implementation and

\footnotetext{
21995 Regional HOV Marketing \& Positioning Research Study. Center for Urban Transportation Research. University of South Florida. Tampa December 1995
} 
maintenance, and other costs. In addition to cost information, the survey requested data about the employer type, location, and the number of employees at the site from 6 a.m. to 10 a.m. The following results were estimated after the survey data was extrapolated to the regulated population:

\section{Table 2. Regulation XV Cost Survey.}

\begin{tabular}{|l|l|}
\hline Performance Measure & Result \\
\hline Regulation XV annual costs & \$162 million \\
\hline Annual Reduction of vehicles & 53,910 vehicles \\
\hline Daily trips eliminated each year trips & 13.75 million \\
\hline Employees per reduced vehicle & 29 employees per reduced vehicle \\
\hline Average annual expenditure per employee & \$105 per year \\
\hline
\end{tabular}

One major finding was the weak correlation between the amount spent and the commute trip reduction received. In other words, high expenditures were not necessarily result in the largest changes in average vehicle ridership.

However, the study also ignored the benefits accruing to those businesses associated with reduction in employee trips. Benefits such as decreased demand for parking; improved employee morale and productivity may offset some or all of the costs and show the cost-effectiveness of the program.

A follow-up examination of the results casts doubt on the accuracy of the self-reported data. Due to a wide variety of responses, the SCAQMD directed Ernst \& Young to re-survey some employers to determine why there was a wide variance in annual per employee costs among employers. They interviewed a sample of 20 employers who responded to Ernst \& Young's first survey to clarify their responses. The sample included 10 of the 50 employers reporting the highest costs and 5 each from the middle and lower levels. Ernst \& Young found that 90 percent of the companies who reported the highest costs had overstated their costs. Over the entire sample, the total revised costs were about 50 percent less than the original estimates. This small sample may not represent the surveyed population. However, the full survey may provide a conservative estimate of the compliance costs.

SCAQMD also found that employers were including costs associated for providing the program to employees other than those regulated (i.e., employees who arrive outside the regulated morning peak period of $6 \mathrm{AM}$ to $10 \mathrm{AM})$. The focus of this survey was on estimating the cost of complying with the regulation, not the total investments made by businesses. For example, an employer may have pragmatically decided to offer a particular benefit to all employees (e.g., $2^{\text {nd }}$ and $3^{\text {rd }}$ shift workers) rather than limit it to those who arrive within the morning peak period. 
The investment in TDM is anything but trivial from a business perspective. For example, the State of Washington's Commute Trip Reduction program estimates that employers invest $\$ 12$ for every $\$ 1$ spent by public agencies. ${ }^{3}$ However, SCAQMD survey, as many others, did not inquire about the benefits received by the employers for this investment (e.g., reduction in parking spaces). This glaring omission can mislead employers - as well as policymakers - as to the value of TDM program to the employer as well as the commuter and the community.

While the focus has been on the cost to business, there are also intangible business and societal benefits touted by government for the purpose of encouraging employer voluntary participation in commuter choice programs.

The transportation literature was largely void of rigorous studies that document the link between the TDM strategies and tangible business benefits such as reducing the need to build parking. Attempting to quantify the value of seemingly harder-to-measure benefits, such as improved employee morale and job satisfaction and reduced employee stress and attribute such benefits to TDM is also extremely challenging. While human resource (HR) managers have trouble measuring the value of work/life initiatives, some believe that the most significant work/life initiatives are the less tangible ones, such as flexibility and provision of day care facilities. The next section identifies methods for measuring the costs or savings for key business benefits.

These solutions aim at increasing the desirability among employers for TDM strategies to solve business problems such as employee turnover and parking. Understanding the role of the employer in influencing employee travel behavior is the first step toward addressing how to demonstrate the benefits of TDM to business.

\section{Understanding How TDM Benefits Business}

How people choose to travel is intricately linked with and influenced by the policies of their employer. For example, parking policies determine how much an employee may have to pay for parking or where they may park. Work hour policies affect the employee's ability to adjust their schedule to catch a bus or carpool with a commuter who works for a nearby employer. Overtime requirements influence whether or not the employee is on a reasonably predictable schedule to make a monthly commitment to join a vanpool. The process of evaluating job performance and the degree of information technology support may determine the prospects for employee participation in telework programs at that company. Clearly, employer policies directly influence employee commute behavior on many levels.

\footnotetext{
${ }^{3}$ CTR Task Force 2001 Report to the Washington State Legislature . Washington State Department of Transportation, Transportation Demand Management Office. December 2001 http://www.wsdot.wa.gov/tdm/tripreduction/download/CTR_Report_01.pdf
} 
A review of the literature found the following benefits cited when discussing the business benefits of TDM.

- Reduce Overhead Costs. Increased competition and need to build shareholder value place more pressure on businesses to lower their cost of doing business as well as increase revenues and/or margins. Strategies such as telecommuting and parking management can make a difference. Telecommuting can reduce office space requirements. Parking management can eliminate the need to build additional parking.

- Enhance Employee Recruitment and Retention. A shrinking labor force has increased competition for qualified applicants. Similarly, the cost of replacing an employee in productivity and direct costs can be very expensive.

- Expand Employee Benefits at Low/No Cost. Employers can take advantage of changes in the federal tax treatment of commute-to-work fringe benefits to benefit employees and reduce costs. Employers can now provide employees with a taxfree benefit and/or offer to subtract the cost of transit, vanpool, or parking as a pre-tax payroll deduction option.

- Enhance Corporate Image. Employers with environmental image problems and/or difficulties with their neighbors often seek to mitigate the problems using a combination of trip reduction strategies.

- Solve Localized Transportation Problems. Employers are well-aware of the value of banding together to address common problems. More employers are joining transportation management associations (TMAs) to address access and mobility problems in their immediate area.

- Expand service hours. Work hour schedules such as flextime, staggered work hour programs, compressed work week programs enable organizations to provide additional coverage with the same total number of employers

- Lower absenteeism and tardiness. Employees may earlier time commitments to their carpool partner or to meet the bus. Telework may allow work to be accomplished when travel to the office isn't possible.

- Increase employment opportunities for the disabled and others unable to meet traditional work hours. Telework provides an alternative to having to physical transport.

- Reduce employee stress. Employee health is significantly related to the distance and duration of the trip. People who are exposed to high levels of traffic congestion arrive at work with higher blood pressure than people who are not exposed. The more sensitive long distance commuters are to the effects of commuting on family life, the greater the inclination to try alternatives to solo driving.

- Enhance employee productivity. One of the oft-cited benefits of telework is productivity increase.

The factors that relate to the profitability of a business must be understood in order to relate TDM strategies in business terms. The following section identifies these factors. 


\section{Factors Contributing to Business Profitability}

There are eight factors that affect the profitability of a business (See Figure 1). TDM strategies can affect one or more of these factors to increase the profitability. There are four main factors that directly change in profit (productivity, cost, margins, and revenue) and an additional four contributing factors (resource quantity, resource price, price, and quantity sold). These main and contributing factors are interrelated. Each main factor is affected by two contributing factors. Each contributing factor affects two different main factors. Understanding how the factors influence profitability will shed light on how various TDM strategies can benefit a business.

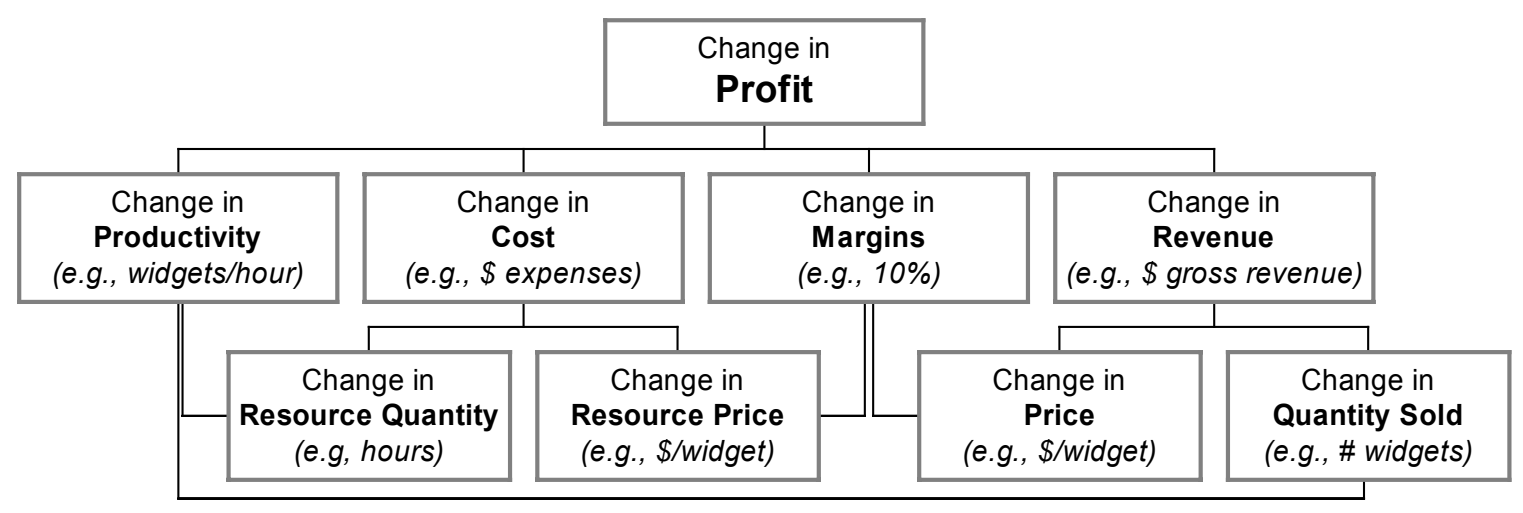

Figure 1. Interrelations of Prices, Products, and Resources to Profit. ${ }^{4}$

Change in Productivity - This factor is positively correlated with profit; i.e., profitability increases as productivity increases, all other factors being equal. Changes in productivity are influenced by changes in the quantity of resources used, such as the number of hours worked by employees, and the volume of products or services sold. Productivity increases, for example, as the sales volume increases for a given resource such as total hours worked. If sales per employee increase from 100 units per employee to 110 units per employee then profitability also increases.

Change in Costs - Perhaps the factor most focused on from a TDM perspective is the change in the costs. Decreasing the costs will increase the profitability holding all other factors constant. Strategies to decrease office space needs, for example, by introducing a telework program, are aimed at reducing overhead costs associated with the space. The quantity of resources used and the price of those resources affect the change in costs. For example, a reduction in square footage and/or reduction of the cost per square foot will reduce the cost of office space. A reduction in costs with the same margins, revenues and productivity factors will result in higher profits.

\footnotetext{
${ }^{4}$ Adapted from James L Riggs and Thomas M. West. Engineering Economics. Third Addition. 1986 p634
} 
Change in Margin - The margin or the contribution to profit related to price is affected by the change in the unit price (e.g., price per product or service) and the resource price (e.g., cost to produce the product or service). TDM strategies can affect changes in margin most likely through changes to the cost to produce the product or service. For example, high absenteeism may require the company to hire additional labor to fill the production task. Reductions in the absenteeism rate may reduce the cost of labor and thus enhance the margins.

Change in Revenues - The remaining factor, change in revenues, is a function of the product's price and the change in the amount of product sold. Though there has been little research to directly attribute TDM strategies to increases in sales, the fact that TDM helps some employers achieve the image of "green" company may contribute to increasing sales based on the consumer support for environmentally friendly companies. Many ISO 14000 companies are requiring suppliers to also becoming ISO 14000 certified may, in fact, require companies to take some environmentally friendly actions or affect sales.

In response to an inquiry about the role of TDM in their environmental management system, Verie Sandborg with Baxter International Inc., "Some of us at corporate are trying to make transportation impacts

\section{Case Study: Beers Construction}

Beers claimed to have achieved the following in the 18 months before ISO 14000 certification:

- Saved over $\$ 230,000$ in waste removal cost by reducing, reusing, and recycling in the first half of 1999.

- An estimated 50,000 cubic yards of waste diverted from landfills.

- Saved over 43,581 vehicle miles through carpooling and public transportation. ( $20 \%$ of Beer employees use public transport

more visible. In our 2000 reporting, we gave an estimate of carbon dioxide emissions for employee commuting to be 100,000 metric tons per year, or approximately two percent of our total global warming impact. Some effort is also being made to require fleet cars to be fuel-efficient."1

Some organizations already include their TDM program in their EMS as part of a larger commitment. Beers, an Atlanta based company, began the ISO 14000 certification process in February 1997. Beers specializes in construction services for a wide range of markets. The company included each of its eight offices in the certification. As part of the certification, Beers employees set up 11 main environmental aspects in areas such as transportation, air emissions, endangered species and wetlands and energy conservation. They report that Beers saved over 43,581 vehicle miles through carpooling and public transportation. ( $20 \%$ of Beer employees use public transport.)

Many TDM strategies are directed at reducing expenses for the employer. However, another method of presenting the impacts would be to relate what would have to happen 
to one of the other factors to achieve a similar change in profitability. For example, TDM could relate the reduction of costs to increases in revenue that would have been required for have a similar contribution to profitability.

Many of these expenses affected by TDM would appear on a business' income statement within the "Selling General and Administrative Expenses (SG\&A)" line item. SG\&A expenses consist of the combined payroll costs (e.g., salaries and commissions executives and employees) and related overhead costs (e.g., advertising, rent, office supplies, legal, accounting and travel expenses). SG\&A expenses are completely separate from the other than the costs of readying the product for sale (i.e., Cost of Goods Sold). SG\&A expenses as a percent of revenue are generally recognized as a leading indicator of administrative productivity and can provide an accurate picture of how well a company is managing the costs required for its sales revenue.

Limiting SG\&A expenses to a certain percentage of revenue can be a significant challenge for almost any business. Controlling expenses is usually accomplished through tactics such as cost-cutting initiatives and employee lay-offs. The need for controlling costs can be due to a variety of reasons. For example, if a competitor lowers its price and the business must respond in kind then the business must seek to reduce the costs of production if it is to maintain a certain gross profit percentage. Companies may overlook the opportunity to control costs out of concern that the reduction of SG\&A might reduce sales. However, the issue is one of efficiency rather than sales revenue.

One of the financial ratios used to monitor the business' performance is the SG\&A to Sales ratio. A steady or decreasing percentage of the SG\&A to Sales ratio indicates that the company is controlling its overhead expenses. This ratio is the percentage of selling, general and administrative costs to sales and is determined by dividing the Selling, General \& Administrative Expenses by Sales revenue.

Table 3. Distribution of Annual Revenue and SG\&A Costs During the Period 1979 1998 (millions of dollars).

\begin{tabular}{|c|c|c|c|c|c|}
\hline & Mean & $\begin{array}{l}\text { Standard } \\
\text { Deviation }\end{array}$ & Median & $\begin{array}{l}\text { Lower } \\
\text { Quartile }\end{array}$ & $\begin{array}{c}\text { Upper } \\
\text { Quartile }\end{array}$ \\
\hline Sales revenue & $\$ 1,277.09$ & $\$ 5,983.43$ & $\$ 87.53$ & $\$ 17.51$ & $\$ 447.75$ \\
\hline $\begin{array}{l}\text { Selling, general and } \\
\text { administrative costs }\end{array}$ & $\$ 299.45$ & $\$ 1,042.49$ & $\$ 17.49$ & $\$ 4.56$ & $\$ 79.12$ \\
\hline $\begin{array}{l}\text { SG \& A as a } \\
\text { percentage of revenue }\end{array}$ & $26.41 \%$ & $17.79 \%$ & $22.62 \%$ & $12.66 \%$ & $34.31 \%$ \\
\hline
\end{tabular}

Source: Anderon, Mark C., Rajiv D. Banker, Suya Janakiraman. "Are Selling, General, and Administrative Costs "Sticky"?. School of Management, University of Texas. October 24, 2000.

As partially reflected in the large standard deviation in the above table, SG\&A across companies and industries makes it difficult to generalize what is the appropriate SG\&A 
rate across industries and how to position the impacts of TDM. For example, SG\&A expenses account for 16.3 percent for Best Buy ${ }^{5}$ and 24.1 percent of expenses for MCI. ${ }^{6}$

One way to position the savings to SG\&A is in terms of additional revenue necessary to maintain the same SG\&A to sales ratio. For example, Costco's average selling, general and administrative expenses, or SG\&A, per store grew $11.3 \%$ in fiscal $2000,3.8 \%$ in 2001 and $4.3 \%$ in 2002, surpassing the rate of sales growth in each of those years. SG\&A climbed to $9.4 \%$ of sales in fiscal ' 02 from $8.6 \%$ in 2000 . Sales increases to necessary to offset increases in SG\&A can be very significant. One report cites analysts' views that "Costco needs to grow monthly same store sales by $70 \%-80 \%$ to offset further increases in SG\&A." Clearly, rising SG\&A rates require companies to increase revenues to maintain their ratios. Falling SG\&A rates would allow a company's revenues to fall by an equivalent share (assuming COG also declined proportionately) and still maintain the same rate of profit.

There are several reasons why businesses may benefit from examining TDM strategies that affect SG\&A expenses. First, businesses can track the SG\&A ratio over time to assess its impact on revenues and profits to improve planning. They also may monitor SG\&A as a measure of how the company is managing its knowledge-based employees. Finally, monitoring SG\&A rations can help some businesses understand the marketing and sales expenditures that may be a significant portion of its costs. One study reported that the sales and marketing expenses accounted for more than 55 percent of SG\&A expenses. $^{8}$

The key for controlling SG\&A expenses is for each company to carefully review those expenses and maintain an ongoing review to further improve the bottom line. Increased control over SG\&A should lead to increase efficiency, productivity, and profits. ${ }^{9}$ Positioning TDM strategies such as the introduction of pretax payments and/or copayments by business for qualified transportation fringe benefits (as well as several other TDM strategies) offers an opportunity for a company to reduce its SG\&A.

\footnotetext{
${ }^{5}$ Best Buy's Q4 sales rise, but net slips. TWICE; New York; Apr 7, 2003; Jeff Malester;

${ }^{6}$ The new MCI. Business Communications Review; Hinsdale; May 2003; Eric Krapf;

${ }_{8}^{7}$ Bigger and better. Barron's; Chicopee; May 12, 2003; Mark Veverka;

http://www.benchmarkingreports.com/businessoperations/op74_administrative_productivity.asp\#Benchmark $\% 20$ Class

${ }^{9}$ Understanding Selling, General And Administrative Expenses http://www.smartbiz.com/sbs/arts/sba33.htm
} 


\section{Benefits of TDM - Business' Perspective}

No comprehensive evaluation of business benefits of TDM was found during the course of the literature review. There are at least three plausible reasons why there is a void in the direct linkage of business benefits and TDM. First, evaluations on TDM focus on the motivations of the funders, typically public environmental or transportation agencies most interested in reducing vehicle trips, vehicle miles of travel, and/or emissions. Second, employers base commute related decisions on regulatory requirements and employee requests without the quantitative rigor of other business decisions. For example, TCRP B-4 Cost-Effectiveness of TDM study found that employers base decisions as to which are the most appropriate TDM strategies on employee requests and business objectives. Rarely were baseline measures on transportation impacts or business objectives identified at the outset. Or they may choose not to report the program's impacts to protect their business advantage. Finally, the cause-and-effect relationship of specific TDM strategies is difficult to discern due to the numerous factors that could influence program impacts such as changes in gasoline prices and the economy.

The lack of data does not suggest that employers don't value the contributions TDM makes to overall business goals. It is abundantly clear that employers do adopt TDM strategies and may exceed minimum requirements when they recognize the value of the programs to meeting business objectives. The following case studies summarize the programs and benefits as seen by from leading businesses.

\section{Case Study: Walt Disney Company}

A noteworthy example of a comprehensive TDM program aligned with business needs can be found at The Walt Disney Company in Southern California. ${ }^{10}$ The Walt Disney Company in Southern California is located in the South Coast Air Basin, which is regulated by the South Coast Air Quality Management District (SCAQMD) and subject to SCAQMD Rule 2202 to reduce emissions by various options including TDM. Several years ago, this SCAQMD changed the rule to allow companies to opt out of TDM programs by choosing another method of compliance, (e.g., scrapping old vehicles or paying on a per employee basis to an Air Quality Investment fund used to underwrite programs and services that demonstrate reductions in vehicle emissions.)

The Walt Disney Company chose to continue its 'good faith' effort to meet a 1.5 AVR instead of the other options. According to Linda Ballew, Manager Corporate Commuter Transportation, there were several business reasons why this was done:

- Scrapping old vehicles or paying a dollar amount per employee to the District does not help employees get to work;

\footnotetext{
${ }^{10}$ Personal communication with Linda Ballew, Manager Corporate Commuter Transportation, Walt Disney Company
} 
- By subsidizing transit for employees Disney is underwriting and supporting the expansion and development of public transit in the region

- Disney has commitments to the communities in which it operates (cities of Burbank and Anaheim) to meet requirements under site-specific plans. Failure to meet these commitments could impact future development in this region.

- Disney has historically supported conservation of resources, air, water, land, and that tradition would have been inconsistent with the other compliance options provided by the District.

- Disney invests heavily in clean fuel technologies within the Disneyland and WDW Resorts, and for Cast shuttles. It would have been inconsistent with this long time emphasis for it to abandon its rideshare program.

- Parking at some locations is in critical supply and the reduction of vehicles is a business necessity.

- Disney encourages employee involvement in the environment at an individual level, both personally and professionally. To abandon support for ridesharing would jeopardize this position.

- In light of the 1994 Northridge quake, subsequent El Nino activity in the area, and the current concern for safety and security, having a fully realized rideshare system means that Disney can react quickly and effectively in transporting employees in the event of an emergency (this was proved in the 1994 earthquake).

- Program benefits are extended to all employees at all sites (regardless of regulatory status) and all shifts, 24/7, --about 38,000 employees, so Disney is doing much more than is required by the district.

- Moving from a "good faith" effort to a target based compliance option did not seem a good business decision for this company.

Currently, Disney offers the following comprehensive program in Southern California:

- Subsidies for public transit (equals $50 \%$ to a maximum of $\$ 60$ )

- Points for daily participation in vanpool, carpool, transit, bicycle, walk, telecommute and compressed work week (equals $\$ 1$ a day)

- Bonus points for enrollment, referral and special challenge days and weeks

- Emergency ride home

- Vanpool program (company subsidized) -- Between 60-70 vans on average

- Customer service locations in two counties at four major locations

- Web site for recording and redeeming points

- Full marketing and promotion of services and incentives

- Management reports by division/dept. on activity

- Swipe card reporting for those without access to a computer

- Bicycle program and incentives

- Inter-site shuttles for L. A. County employees between buildings

- On-site purchase of subsidized (discount) train tickets

- Pretax transit and vanpool benefits (rollout to be completed by third qtr 2002)

- A 4/40 - 9/80 (compressed workweek) policy at the Disneyland Resort 
- Fairs and informational events

- Opportunity drawings and gifts

- Other services include: commute assistance, ridematching, focus groups, newsletter, etc.

Elements of the program are available to Disney employees working in 10 states on the east coast:

- Pretax transit and parking benefits through WageWorks.

According to Ballew, Walt Disney Company realizes a range of quantitative and qualitative benefits:

- Reduction in size of parking structure (saved \$2M) due to level of rideshare participation

- Saved significant costs $(\$ 200,000+)$ over hiring outside consultants to provide commuting data in development planning

- Reduced parking demand for Cast Members at Resort to offset potential shortfalls of parking on busy summer days (unquantifiable)

- Competitiveness in hiring (never been quantified)

- Meeting requirements of Environmental Impact Reports, which require traffic mitigation (not quantified)

- Keeping in compliance with the SCAQMD Rule 2202 (non-compliance can cost up to $\$ 50,000$ a day)

- Keeping in compliance with Burbank Site Specific Plan (non-compliance could impact development)

- Keeping in compliance with the Disneyland Resort Specific Plan with the City of Anaheim (non-compliance would impact the development of a planned third gate)

- Providing a needed benefit to employees (unquantifiable)

- Helping to underwrite the development and expansion of transit services and routes in Southern California (unquantifiable)

- Coordinated with transit agencies and TMA/TMO's the development and planning of future transportation services (unquantifiable).

- Provides a backup plan for emergency situations (prevented the loss of millions in productivity after the 94 quake.

- Promotes the image of the Disney Company as an environmentally aware company (unquantifiable)

Currently, about one-third of employees participate regularly in Disney's programs.

Part of the challenge in quantifying the business benefits of TDM is the lack of data from employers. This isn't entirely surprising as Disney, for example, will not make cost information available outside the company. In the case of Disney, however, the costs are considered minimal, at a per head basis and are considered to be a very inexpensive benefit. 
Finally, Disney has an investment well into the billions in Southern California; if traffic and air quality become significantly worse, it will impact the travel and resort business well into the millions. She states, "It is a small investment to provide a comprehensive rideshare program to help offset this problem. Hopefully, other companies will take our model and move to take this problem seriously also."

As the literature and interviews with award-winning programs illustrate, the failure to quantify the benefits in business terms is not a deal breaker, even for those investing hard cash. There is an intrinsic value placed by many of these companies on the programs. These programs also tend to evolve as the employers seek to balance the program features with changing needs.

\section{Case Study: Nike}

Nike is an example of a business learning to adapt the TDM program to reduce their costs while increasing the benefits to the company. In 1992, Nike was offering employees $\$ 1$ voucher per day, called "Nike Bucks", to be used in the company cafeteria, gift shop, daycare center or fitness center. Employees using transit received a comparable discount on the cost of a monthly pass. As the number of Nike employees grew and moved to other locations, the voucher program became difficult to administer as well as costing in excess of $\$ 200,000$. Nike replaced the voucher program with "Traveling Responsibly via Alternative Commuting," or TRAC. TRAC offers monthly prize drawings, with prizes valued from $\$ 60$ to $\$ 200$. The program has yielded a lower drive-alone rate $(79 \%)$ than with the Nike buck program $(84 \%)$ and is costing $\$ 43,000$ per year.

According to Linda Bainbridge, Nike's transportation specialist, the Nike Buck program costs got out of hand as more people started to commute by alternative mode. She said she tracks participation in SOV trip reduction according to the number of persons who electronically sign up for monthly and quarterly prize drawings, in addition to the weekly ridership numbers collected for Nike's shuttle from the work site to a light rail station $1 / 2$ mile away.

The cost burden of the prize drawings approach is easier and cheaper than the Nike Bucks because it is a fixed cost so it does not matter how many participate. She believes that the prizes attract people to use alternative transportation; but she also said that many carpoolers do not register for the prizes and that while over 300 carpoolers per week sign up, the trip reduction survey, in which she surveys approximately 500 employees, indicates a participation rate of $24 \%$.

While Nike is currently under a trip reduction mandate, their program started many years before the mandate. Nike has a corporate philosophy of "doing the right thing" on behalf of employees as well as for society. Since the program has management support, Bainbridge does not attempt to quantify benefits from the program. It comes down to management concern about business sustainability over the long haul. So the self-interest 
is there in a desire to conduct business in a way that is perceived to sustain the company for the long term. ${ }^{11}$

\section{Case Study: Bayer Corporation}

Similarly to Nike, Inc., the Bayer Corporation work site in Berkeley is mandated to conduct trip reduction activities but they do more than they have to because it makes business sense. Deborah Bellush, Site Development/Community Relations Manager, said that prior to the mandate, they already had a shuttle in place and had implemented carpool parking. According to Bellush, without the mandate, they probably would not be going to the lengths they now are. With the mandate, it is as though they think they might as well make it a good effective program if they have to have one anyway. Bellush reported that Bayer spends on the order of $\$ 300,000$ per year on alternative transportation assistance with a participation rate of 400 employees out of 1,200. The program has been in place for 10 years.

She said there are benefits but they are very hard to quantify. Benefits from the program include a reduction in parking needs. The City requires employers to park on their own property. Since the commute is "horrendous", participants are happy to have a program that improves their quality of life. Bayer pays $75 \%$ of the cost of a shuttle to a BART station that the rest of the community can also use, so there is a community relations benefit to Bayer. Bellush said that if everything else were the same between Bayer and another company, the $\$ 45 /$ mo per employee subsidy for vanpooling would give them an edge by making Bayer an employer of choice.

While Bayer does not quantify many of the benefits, the cumulative value of the program means that the investment significantly exceeds development agreement thresholds. In an overview of the Bayer Trip Reduction Program for the year 2001, Bayer reported that the trip reduction program cost more than $\$ 288,000$, as compared to the estimated cost of $\$ 35,000 /$ year, as specified in their development agreement. Bayer also contributed $\$ 78,716$ to the Berkeley Gateway TMA for the West Berkeley shuttle, which is $\$ 28,716$ more than mandated under the 1999 Amendment to the development agreement. ${ }^{12}$

\section{Case Study: Georgia Pacific}

Failure to examine the costs and benefits of the extensive programs isn't unusual. According to Robin Taylor with Georgia-Pacific (G-P), the company does not conduct surveys to relate the cost of their investment in commuter assistance to benefits derived. These costs are not trivial but the costs are compared with alternatives such as parking.

\footnotetext{
${ }^{11}$ Linda Bainbridge. Transportation Specialist, Nike, Inc. Portland, Oregon (From TDM Review

12 Personal communication. Deborah Bellush. Site Development/Community Relations Mgr., Bayer Corporation, Berkeley, CA
} 
Costs cited by Taylor include approximately $\$ 100$ per participating employee per month for commuter assistance, which includes $\$ 70$ per month for vanpool subsidy plus cash prizes and other perks.

G-P also has learned to adapt the program like Nike. The vans used to be fully subsidized at $\$ 100$ per month per employee, costing G-P \$8,000 per month per van. Now they have 11 operating vans, and G-P required participants co-pay $\$ 30$ per month. So now vans cost $\$ 1,000$ per month per van for the 11 vans. G-P is paying $\$ 132,000$ per year in vanpool subsidies, which is offsets the need for additional parking spaces.

Unlike the previous examples, G-P is not required by a local trip reduction regulation or other mandate to provide these benefits. Taylor cites that the benefits accruing to G-P are what they get from the employee in return, which is improved productivity, improved morale, improved employee retention, and good public relations. The company recognizes costs a lot to get and retain good people, but this has not been quantified.

Georgia-Pacific was motivated to participate in The Clean Air Campaign to achieve three goals: further its environmental efforts, offer an attractive benefit for its employees, and, at one metro area location, reduce parking demand by 130 spaces to avoid a $\$ 100,000$ surface lot expansion cost. Since 1997, Georgia-Pacific has invested more than $\$ 2.5$ million in environmental projects across the country allowing the company to meet all three goals.

In the downtown corporate office, 55percent of the company's 3,000 employees participate in its Clean Air Campaign program. At the company's Distribution Division Headquarters in the Cumberland area of Cobb County, more than 16-percent participate and this location has successfully avoided the parking crisis that it faced in 1997.

\section{Case Study: Georgia Pacific}

In just one year, transit ridership among downtown Georgia-Pacific employees increased $10 \%$ and the number of carpools increased by $57 \%$.

The teleworking pilot program measured improved productivity and job satisfaction and a reduction in absenteeism.

The Cumberland distribution center avoids a $\$ 100,000$ parking expansion through carpooling, vanpooling and transit usage.

The challenge in evaluating the impact of any TDM program can be found in the diversity of programs and incentives offered by the company. Georgia-Pacific offers employees: carpool and vanpool ridematching; subsidized vanpools; a subsidized transit pass program; alternative work schedules; teleworking; biking and walking programs. Ongoing education efforts include the use of brochures, periodic Lunch n' Learns, email and the company Intranet. The Cumberland location was able to supplement its company transit subsidy with an additional discount offered by the area transportation management association. 
Monthly drawings for prizes encourage continued participation. Other incentives include free car washes or oil changes for carpoolers; and complimentary access to the company health club showers for bike riders. During smog season, the company also institutes operations and maintenance changes by asking landscape contractors to postpone services on Smog Alert Days until after 6:00 PM.

Participation in the program is voluntary but the incentives and communications have resulted in a high percentage of participation. In just one year, transit ridership among downtown Georgia-Pacific employees increased $10 \%$ and the number of carpools increased by $57 \%$. The teleworking pilot program also measured improved productivity and job satisfaction and a reduction in absenteeism. The Cumberland distribution center continues to avoid a costly parking expansion.

\section{Approaches to Assessing the Impacts of Business Benefits}

Similarities exist between measuring the business benefits of TDM and assessing the impacts of work/life interventions to address the changing needs of the workforce. According to Lobel and Faught, there are four main approaches to measuring the value added of work/life support programs. ${ }^{13}$

- The human-cost approach highlights the reduced labor costs associated with specific interventions.

- The human-investment approach emphasizes the long-term payoffs associated with meeting employee work/life needs.

- The stakeholder approach identifies benefits that accrue to important organizational stakeholders, such as shareholders, employees, and customers, as a result of specific work/life interventions.

- The strategy approach demonstrates how work/life supports reinforce broad business strategies, such as globalization or providing superior customer service.

These methods also correspond to four criteria regarding the selection of approaches for measuring value. The questions include:

1. What is the specific work/life intervention?

2. How much does the intervention cost?

3. Who benefits from the intervention?

4. How is the effectiveness of the intervention measured?

The human-cost approach is the easiest way to measure the value that work/life investments and demonstrating the reduction of labor costs. Tracking absenteeism and turnover rates and costs before the intervention is offered and comparing those rates to

\footnotetext{
${ }^{13}$ Lobel, Sharon and Leslie Faught, "Four Methods for Proving the Value of Work/life Interventions," Compensation and Benefits Review, Nov/Dec 1996, Vol. 28, No.6, pp. 50-57.
} 
rates measured after the intervention is provided can do this. Another way is to compare rates between users and nonusers of the intervention. Turnover rates can provide the information needed to calculate the savings as a result of reduced employee termination costs, employee hiring costs and training costs.

In the human-investment approach, workers are assets in which the firm wants to invest. work/life initiatives, including various TDM-related strategies like compressed work week programs, are investments in human capital rather than as a means of reducing labor costs. ${ }^{14}$ The long-term payoff tends to be retention of high-performing employees.

In the stakeholder approach, the emphasis is proving the value of the work/life initiative with positive impact on some stakeholder group of concern, such as employees, shareholders, customers, suppliers and the government. It is recommended to identify a wide range of possible stakeholders, then select the most relevant to consider. For example, a study by Chauvin and Guthrie showed that public companies that appeared on the list of best companies for working mothers, published by the magazine, Working Mother, had a small but statistically significant increase in their stock prices. ${ }^{15}$

Whether the employers implicitly or explicitly quantify the benefits of TDM to their business, the need remains for tools to help quantify the business as well as the community benefits of TDM.

\footnotetext{
${ }^{14}$ Professor Kathleen Christensen, City University of New York

${ }^{15}$ K. Chauvin and J. Guthrie, "Labor Market Reputation and the Value of the Firm," Managerial and Decision Economics, Vol. 15, 1994, pp. 543-552.
} 


\section{Chapter 2 - Existing Tools for Calculating Costs and Benefits}

This chapter provides an overview of the current tools commonly used to assist employers in predicting the changes in travel behavior due to TDM and/or estimates the benefits accruing to businesses. Four models are briefly reviewed: EPA's COMMUTER Model, EPA's Business Benefits Calculator, FHWA's Commuter Choice Decision Support System, and FDOT-funded CUTR_AVR.

\section{EPA's COMMUTER Model}

The Environment Protection Agency's (EPA) COMMUTER Model is designed to analyze the impacts of TDM programs in regard to mode share, vehicle miles, vehicle trips and emissions. This model can be used to estimate the number of vehicle trips reduced to help estimate the savings by reducing the need to construct parking garage. It can also be used to measure changes in alternative work hour programs as well as changes in mode splits due to changes in parking and/or commute subsidies.

The COMMUTER Model uses two procedures for calculating travel response to TDM strategies:

1.Logit pivot-point model: A multimodal pivot-point model using coefficients and computational procedures from accepted logit-based mode choice models;

2.Look-up tables: The impacts of some strategies are estimated using relational factors from empirical research. The impacts are arrayed in lookup tables where increments of change are associated with particular types of programs, reflecting different application assumptions, levels of intensity, and setting.

The COMMUTER Model is essentially used as part of a three-step procedure, which can be followed for the area and employer worksite levels:

1. The user establishes a baseline by supplying essential information on current conditions (e.g., current mode split).

2. An analysis scenario is selected from among available program options.

3. Changes in peak and non-peak vehicle trips and vehicle miles of travel are calculated and used to estimate the change in emissions using the logit component and look-up tables.

The baseline is established by entering data inputs for local demographic, mode splits, and alternative work schedule. The fact that COMMUTER is a pivot-point model means that the higher the levels of use of a particular mode, for example, then greater the impact. For example, an employer providing $\$ 1$ per day subsidy for transit benefits provided to employees will have a lower shift to transit for an employer with a transit share of $2 \%$ versus another employer with a transit share of $10 \%$, holding all other factors constant. 
There are a wide variety of TDM program options that can be analyzed by the COMMUTER model. The four primary program areas include: site access; financial incentives and parking costs; employer support programs; and alternative work schedule programs. Table 2 shows the options under each of these areas, how they are measured and what additional information is required.

Table 4. COMMUTER Model Inputs.

\begin{tabular}{|c|c|c|}
\hline Categories & Sub-category & Inputs \\
\hline \multirow[t]{5}{*}{ Demographic } & \multirow[t]{3}{*}{ Metropolitan Area Size } & Small (Under 750,000) \\
\hline & & $\begin{array}{l}\text { Medium }(750,000 \text { to } 2 \\
\text { million) }\end{array}$ \\
\hline & & Large (Over 2 million) \\
\hline & \multirow[t]{2}{*}{ Employment in area } & Office employment \\
\hline & & Non-office employment \\
\hline \multirow[t]{16}{*}{ Work Trip Characteristics } & \multirow[t]{7}{*}{ Modes } & Auto- Drive Alone \\
\hline & & Auto- Carpool \\
\hline & & Vanpool \\
\hline & & Transit \\
\hline & & Bicycle \\
\hline & & Walk \\
\hline & & Other \\
\hline & \multirow[t]{4}{*}{ Work Trip Length } & Average person \\
\hline & & Average trip length \\
\hline & & Average trip length \\
\hline & & Average trip length \\
\hline & \multirow[t]{2}{*}{ Vehicle Occupancy } & Average carpool occupancy \\
\hline & & $\begin{array}{l}\text { Average vanpool } \\
\text { occupancy }\end{array}$ \\
\hline & \multirow[t]{2}{*}{ Peak Period Travel } & Length of peak period \\
\hline & & $\begin{array}{l}\% \text { of work trips in peak } \\
\text { period }\end{array}$ \\
\hline & Transit Characteristics & Average transit speed \\
\hline \multirow{5}{*}{$\begin{array}{l}\text { Mode Choice Model } \\
\text { Coefficients }\end{array}$} & In Vehicle Travel Time & Transit Time \\
\hline & \multirow{2}{*}{$\begin{array}{l}\text { Out of Vehicle Travel } \\
\text { Time }\end{array}$} & Walk time \\
\hline & & Transit time \\
\hline & \multirow[t]{2}{*}{ Costs } & Auto-parking \\
\hline & & Transit fare \\
\hline \multirow[t]{4}{*}{ Existing employer support } & Carpool & Levels 1-4 \\
\hline & Vanpool & Levels 1-4 \\
\hline & Transit & Levels 1-4 \\
\hline & Bicycle & Levels 1-4 \\
\hline
\end{tabular}




\begin{tabular}{|l|l|l|}
\hline Categories & Sub-category & \multicolumn{1}{l|}{ Inputs } \\
\hline Alternative Work Schedule & Telecommuting & Average days per week \\
\cline { 2 - 3 } & Flextime/Staggered hours & $\%$ of trips shifted from peak \\
\cline { 2 - 3 } & Existing Participation rates & Flextime \\
& & CWW 4/40 or 9/80 \\
\cline { 3 - 3 } & & Staggered hours \\
\cline { 3 - 3 } & & Telecommuting \\
\hline
\end{tabular}

The model provides three types of outputs: change in mode share, change in vehicle miles of travel/vehicle trips reduced and emission reductions. The costs for implementing the strategies inputted into the model as well as the business benefits accruing to the worksite are not outputs of the model.

The COMMUTER Model does not output the business benefits directly. EPA's Business Benefits Calculator (to be discussed in the next section) uses look-up tables developed from a sensitivity analysis using the COMMUTER Model to estimate some of these benefits.

Table 5. TDM Program Options.

\begin{tabular}{|c|c|c|c|}
\hline Program Areas & $\begin{array}{l}\text { Specific } \\
\text { Programs }\end{array}$ & Measured by... & Factors \\
\hline \multirow[t]{9}{*}{ SITE ACCESS } & $\begin{array}{l}\text { Remote parking for } \\
\text { SOVs }\end{array}$ & $\begin{array}{l}\text { Change in Walk Access } \\
\text { Time (minutes) }\end{array}$ & $\begin{array}{l}\text { Workforce } \\
\text { Participation }\end{array}$ \\
\hline & $\begin{array}{l}\text { Preferential parking for } \\
\text { carpoolers }\end{array}$ & $\begin{array}{l}\text { Change in Walk Access } \\
\text { Time (minutes) }\end{array}$ & $\begin{array}{l}\text { Workforce } \\
\text { Participation }\end{array}$ \\
\hline & $\begin{array}{l}\text { Preferential parking for } \\
\text { vanpoolers }\end{array}$ & $\begin{array}{l}\text { Change in Walk Access } \\
\text { Time (minutes) }\end{array}$ & $\begin{array}{l}\text { Workforce } \\
\text { Participation }\end{array}$ \\
\hline & Closer transit stop & $\begin{array}{l}\text { Change in Walk Access } \\
\text { Time (minutes) }\end{array}$ & $\begin{array}{l}\text { Workforce } \\
\text { Participation }\end{array}$ \\
\hline & Shuttle from transit stop & $\begin{array}{l}\text { Change in Walk Access } \\
\text { Time (minutes) }\end{array}$ & $\begin{array}{l}\text { Workforce } \\
\text { Participation }\end{array}$ \\
\hline & $\begin{array}{l}\text { Closer bicycle parking } \\
\text { facilities }\end{array}$ & $\begin{array}{l}\text { Change in Walk Access } \\
\text { Time (minutes) }\end{array}$ & $\begin{array}{l}\text { Workforce } \\
\text { Participation }\end{array}$ \\
\hline & $\begin{array}{l}\text { Improved pedestrian } \\
\text { access }\end{array}$ & $\begin{array}{l}\text { Change in Walk Access } \\
\text { Time (minutes) }\end{array}$ & $\begin{array}{l}\text { Workforce } \\
\text { Participation }\end{array}$ \\
\hline & $\begin{array}{l}\text { More frequent transit } \\
\text { service }\end{array}$ & $\begin{array}{l}\text { Change in avg. headway } \\
\text { (minutes) }\end{array}$ & $\begin{array}{l}\text { Workforce } \\
\text { Served } \\
\text { Increased Transit } \\
\text { VMT }\end{array}$ \\
\hline & Faster transit service & $\begin{array}{l}\text { Change in route travel } \\
\text { time (minutes) }\end{array}$ & $\begin{array}{l}\text { Workforce } \\
\text { Served } \\
\text { Increased Transit } \\
\text { VMT }\end{array}$ \\
\hline
\end{tabular}




\begin{tabular}{|c|c|c|c|}
\hline Program Areas & $\begin{array}{l}\text { Specific } \\
\text { Programs }\end{array}$ & Measured by... & Factors \\
\hline \multirow{9}{*}{$\begin{array}{l}\text { FINANCIAL } \\
\text { INCENTIVES } \\
\text { AND PARKING } \\
\text { COSTS }\end{array}$} & $\begin{array}{l}\text { Increased parking cost } \\
\text { for SOVs }\end{array}$ & Parking cost (\$) & $\begin{array}{l}\text { Workforce } \\
\text { Participation }\end{array}$ \\
\hline & $\begin{array}{l}\text { Parking discount for } \\
\text { carpools }\end{array}$ & Parking cost (\$) & $\begin{array}{l}\text { Workforce } \\
\text { Participation }\end{array}$ \\
\hline & $\begin{array}{l}\text { Parking discount for } \\
\text { vanpools }\end{array}$ & Parking cost (\$) & $\begin{array}{l}\text { Workforce } \\
\text { Participation }\end{array}$ \\
\hline & Parking Cash out & $\$ /$ month $/ 20$ & $\begin{array}{l}\text { Workforce } \\
\text { Participation }\end{array}$ \\
\hline & Transit Fare reduction & $\$ /$ month $/ 20$ & $\begin{array}{l}\text { Workforce } \\
\text { Participation }\end{array}$ \\
\hline & VP subsidy & $\$ /$ month $/ 20$ & $\begin{array}{l}\text { Workforce } \\
\text { Participation }\end{array}$ \\
\hline & Transit Pass subsidy & Transit discount (\$) & $\begin{array}{l}\text { Workforce } \\
\text { Participation }\end{array}$ \\
\hline & $\begin{array}{l}\text { Financial Incentive for } \\
\text { bicycling }\end{array}$ & (\$) & $\begin{array}{l}\text { Workforce } \\
\text { Participation }\end{array}$ \\
\hline & $\begin{array}{l}\text { Financial incentive for } \\
\text { walking }\end{array}$ & (\$) & $\begin{array}{l}\text { Workforce } \\
\text { Participation }\end{array}$ \\
\hline \multirow{4}{*}{$\begin{array}{l}\text { EMPLOYER } \\
\text { SUPPORT } \\
\text { PROGRAMS }\end{array}$} & Carpool Program & $\begin{array}{l}\text { Change in Program Level } \\
(0-4)\end{array}$ & $\begin{array}{l}\text { Workforce } \\
\text { Participation }\end{array}$ \\
\hline & Vanpool Program & $\begin{array}{l}\text { Change in Program Level } \\
(0-4)\end{array}$ & $\begin{array}{l}\text { Workforce } \\
\text { Participation }\end{array}$ \\
\hline & Transit Program & $\begin{array}{l}\text { Change in Program Level } \\
(0-4)\end{array}$ & $\begin{array}{l}\text { Workforce } \\
\text { Participation }\end{array}$ \\
\hline & Bicycle Program & $\begin{array}{l}\text { Change in Program Level } \\
(0-4)\end{array}$ & $\begin{array}{l}\text { Workforce } \\
\text { Participation }\end{array}$ \\
\hline \multirow[t]{3}{*}{$\begin{array}{l}\text { ALTERNATIVE } \\
\text { WORK } \\
\text { SCHEDULES }\end{array}$} & Flextime & $\begin{array}{l}\text { Change in Eligibility or } \\
\text { Participation (\%) }\end{array}$ & $\begin{array}{l}\text { Present rates of } \\
\text { Telecommuting } \\
\text { and alternative } \\
\text { work schedule } \\
\text { employees }\end{array}$ \\
\hline & Compressed 4/40 & $\begin{array}{l}\text { Change in Eligibility or } \\
\text { Participation (\%) }\end{array}$ & $\begin{array}{l}\text { Present rates of } \\
\text { Telecommuting } \\
\text { and alternative } \\
\text { work schedule } \\
\text { employees }\end{array}$ \\
\hline & Compressed 9/80 & $\begin{array}{l}\text { Change in Eligibility or } \\
\text { Participation (\%) }\end{array}$ & $\begin{array}{l}\text { Present rates of } \\
\text { Telecommuting } \\
\text { and alternative } \\
\text { work schedule } \\
\text { employees }\end{array}$ \\
\hline
\end{tabular}




\begin{tabular}{|l|l|l|l|}
\hline Program Areas & \multicolumn{1}{|c|}{$\begin{array}{c}\text { Specific } \\
\text { Programs }\end{array}$} & Factors \\
\hline & Staggered Hours & $\begin{array}{l}\text { Change in Eligibility or } \\
\text { Participation (\%) }\end{array}$ & $\begin{array}{l}\text { Present rates of } \\
\text { Telecommuting } \\
\text { and alternative } \\
\text { work schedule } \\
\text { employees }\end{array}$ \\
\cline { 2 - 4 } & Telecommute & $\begin{array}{l}\text { Change in Eligibility or } \\
\text { Participation (\%) }\end{array}$ & $\begin{array}{l}\text { Present rates of } \\
\text { Telecommuting } \\
\text { and alternative } \\
\text { work schedule } \\
\text { employees }\end{array}$ \\
\hline
\end{tabular}

NOTE: For area applications (i.e., multiple employers), workforce participation represents the number of commuters who work for employers that offer the particular TDM program.

The COMMUTER Model is used to forecast the impacts of a variety of TDM program scenarios on VMT, vehicle trips, and emission reductions. However, there are challenges and trade-offs that employers may have to make in using it. ${ }^{16}$

Since COMMUTER is based on pivot model, it needs a starting mode share to show any change. This poses a problem for employers with little or no use of a particular mode, such as vanpooling. In order to get the model to recognize vanpooling and a mode share greater than 0 must be established as the starting point. In effect, the model will not show the impacts of new modes or options as well as changes to existing mode shares.

While the COMMUTER model is spreadsheet-based, establishing the baselines or estimating the changes due to certain strategies may be difficult for employers to estimate or even obtain help from the agencies to provide. For example, the section on transit improvements requires data on various changes to transit service (e.g, frequency, speed, etc.) that an employer may not be able to easily estimate. Employers may need to work with transit agency staff to estimate a set of inputs for the model.

The mode share input section also fails to include a "work at home" category. However, it appears on the results page. This can create a misleading picture and creates a situation in which mode share percentages have to be manipulated to remove those that work at home

The level of effort supported by the employer will affect the impact of the programs and strategies. The COMMUTER model developed five scenarios (Level $0=$ no program to Level 4 = subsidies and full-time employee transportation coordinators) to represent levels of support for the transit, carpool, vanpool and bicycle modes. The aforementioned look-up tables use values corresponding to these levels to adjust the final

\footnotetext{
${ }^{16}$ Hagelin, Christopher A. "Opportunities and Limitations of the EPA's Commuter Model” (unpublished) Center for Urban Transportation Research, University of South Florida.
} 
results. The following table provides the general description of each level but some professional judgment may be used to determine the appropriate level. Financial incentives and disincentives (e.g., transit passes, parking charges) are captured separately and used by the logit model portion of the model.

Table 6. Employer Program Support Levels.

\begin{tabular}{|c|c|c|c|c|}
\hline Program & Level 1 & Level 2 & Level 3 & Level 4 \\
\hline $\begin{array}{l}\text { Carpool } \\
\text { Support } \\
\text { Programs }\end{array}$ & $\begin{array}{l}\text { Offers carpool } \\
\text { information } \\
\text { activities (tied in } \\
\text { with area-wide } \\
\text { matching) } \\
\text { and a quarter-time } \\
\text { employee } \\
\text { transportation } \\
\text { coordinator (ETC) }\end{array}$ & $\begin{array}{l}\text { Offers an in-house } \\
\text { carpool matching } \\
\text { service and/or } \\
\text { personalized carpool } \\
\text { candidate get- } \\
\text { togethers (including } \\
\text { information } \\
\text { activities) and a } \\
\text { quarter-time } \\
\text { ETC }\end{array}$ & $\begin{array}{l}\text { Provides in-house } \\
\text { carpool matching and } \\
\text { information services, a } \\
\text { policy of flexible work } \\
\text { schedules* to } \\
\text { accommodate } \\
\text { carpools, and a half- } \\
\text { time ETC }\end{array}$ & $\begin{array}{l}\text { Provides in-house } \\
\text { carpool matching and } \\
\text { information, flexible } \\
\text { work schedules, and a } \\
\text { full-time ETC }\end{array}$ \\
\hline $\begin{array}{l}\text { Vanpool } \\
\text { Support } \\
\text { Programs }\end{array}$ & $\begin{array}{l}\text { Provides vanpool } \\
\text { information } \\
\text { activities (tied in } \\
\text { with area-wide } \\
\text { vanpool } \\
\text { matching and/or } \\
\text { third-part vanpool } \\
\text { programs), plus a } \\
\text { quarter-time } \\
\text { ETC }\end{array}$ & $\begin{array}{l}\text { Provides in-house } \\
\text { vanpool matching } \\
\text { services and/or } \\
\text { personalized vanpool } \\
\text { candidate get- } \\
\text { togethers, and non- } \\
\text { monetary vanpool } \\
\text { development, plus a } \\
\text { quarter-time ETC and } \\
\text { a policy of flexible } \\
\text { work schedules. }\end{array}$ & $\begin{array}{l}\text { Provides in-house } \\
\text { vanpool matching } \\
\text { services; vanpool } \\
\text { development and } \\
\text { operating assistance, } \\
\text { including financial } \\
\text { assistance, such as } \\
\text { vanpool purchase } \\
\text { loan guarantees, } \\
\text { consolidated purchase } \\
\text { of insurance, and a } \\
\text { startup subsidy (note } \\
\text { that such assistance is } \\
\text { different from offering } \\
\text { financial incentives to } \\
\text { use vanpools); and } \\
\text { additional services } \\
\text { such as van washing, } \\
\text { plus a half-time } \\
\text { ETC }\end{array}$ & $\begin{array}{l}\text { Provides in-house } \\
\text { vanpool matching } \\
\text { services; vanpool } \\
\text { development and } \\
\text { operating assistance, } \\
\text { including major financial } \\
\text { assistance, such as } \\
\text { employer purchase of } \\
\text { vans with favorable } \\
\text { leaseback (or alternative } \\
\text { continuing subsidy, such } \\
\text { as free maintenance, free } \\
\text { insurance) in addition to } \\
\text { startup subsidy; several } \\
\text { additional incentives } \\
\text { such as van washing, } \\
\text { guaranteed ride home, } \\
\text { and a full-time ETC } \\
\text { and/or personalized } \\
\text { vanpool candidate } \\
\text { get-togethers. }\end{array}$ \\
\hline $\begin{array}{l}\text { Transit } \\
\text { Support } \\
\text { Programs }\end{array}$ & $\begin{array}{l}\text { Provides a transit } \\
\text { information center } \\
\text { plus a quarter-time } \\
\text { ETC }\end{array}$ & $\begin{array}{l}\text { Provides a transit } \\
\text { information center } \\
\text { and a policy of work } \\
\text { hours flexibility to } \\
\text { accommodate transit } \\
\text { schedules/delays, } \\
\text { plus a quarter-time } \\
\text { ETC }\end{array}$ & $\begin{array}{l}\text { Provides a transit } \\
\text { information center and } \\
\text { a policy of work hours } \\
\text { flexibility, } \\
\text { on-site transit pass } \\
\text { sales, plus a half-time } \\
\text { transportation ETC }\end{array}$ & $\begin{array}{l}\text { Provides a transit } \\
\text { information center and a } \\
\text { policy of work hours } \\
\text { flexibility, } \\
\text { on-site transit pass sales, } \\
\text { guaranteed ride home, } \\
\text { and a full-time ETC }\end{array}$ \\
\hline
\end{tabular}




\begin{tabular}{|c|c|c|c|c|}
\hline Program & Level 1 & Level 2 & Level 3 & Level 4 \\
\hline $\begin{array}{l}\text { Bicycle } \\
\text { Support } \\
\text { Programs }\end{array}$ & $\begin{array}{l}\text { Provides on-site } \\
\text { bicycle parking } \\
\text { (racks or lockers). }\end{array}$ & $\begin{array}{l}\text { Provides bicycle } \\
\text { parking (racks or } \\
\text { lockers) and shower } \\
\text { facilities }\end{array}$ & $\begin{array}{l}\text { Provides secure } \\
\text { bicycle parking } \\
\text { (storage lockers or } \\
\text { indoor storage) and } \\
\text { shower facilities, in } \\
\text { conjunction with local } \\
\text { infrastructure } \\
\text { conducive to } \\
\text { bicycling. This } \\
\text { includes the presence } \\
\text { of (a) off-street bike } \\
\text { paths, (b) on-street } \\
\text { bike lanes, and/or (c) } \\
\text { local streets with light } \\
\text { traffic by which } \\
\text { cyclists can access the } \\
\text { workplace }\end{array}$ & $\begin{array}{l}\text { Provides parking, } \\
\text { shower, and infra- } \\
\text { structure conditions as } \\
\text { for Level 3, and also } \\
\text { sponsoring workplace } \\
\text { promotional activities. } \\
\text { These activities should } \\
\text { include promoting } \\
\text { bicycle commuting, } \\
\text { identifying the } \\
\text { availability and } \\
\text { location of parking and } \\
\text { shower facilities, and } \\
\text { providing local bicycle } \\
\text { route maps, along with } \\
\text { other activities to } \\
\text { encourage bicycle } \\
\text { commuting }\end{array}$ \\
\hline
\end{tabular}

The appendix contains screen captures showing the process of using the COMMUTER Model and the output obtained.

\section{Business Benefits Calculator}

EPA's Business Benefits Calculator (BBC) is an online tool available on the EPA's Commuter Choice website (www.commuterchoice.gov). The purpose of the tool is to assess the benefits and costs of TDM programs to the employer, employees and community. It is also a means for determining if the employer qualifies for the National Standard of Excellence (i.e., Commuter Choice Leadership Initiative), a program intended to brand employers in the country as among the best workplaces in the country for commuters.

Similar to other tools, BBC obtains information about the worksite such as state and location within their urban area (e.g., downtown, suburbs) and the organizational structure (See Figures 3 and 4). Since the qualified transportation fringe benefit option (Section 132(f) of the Internal Revenue Code) can reduce the taxes paid by employers, information about their corporate income tax classification is obtained. 


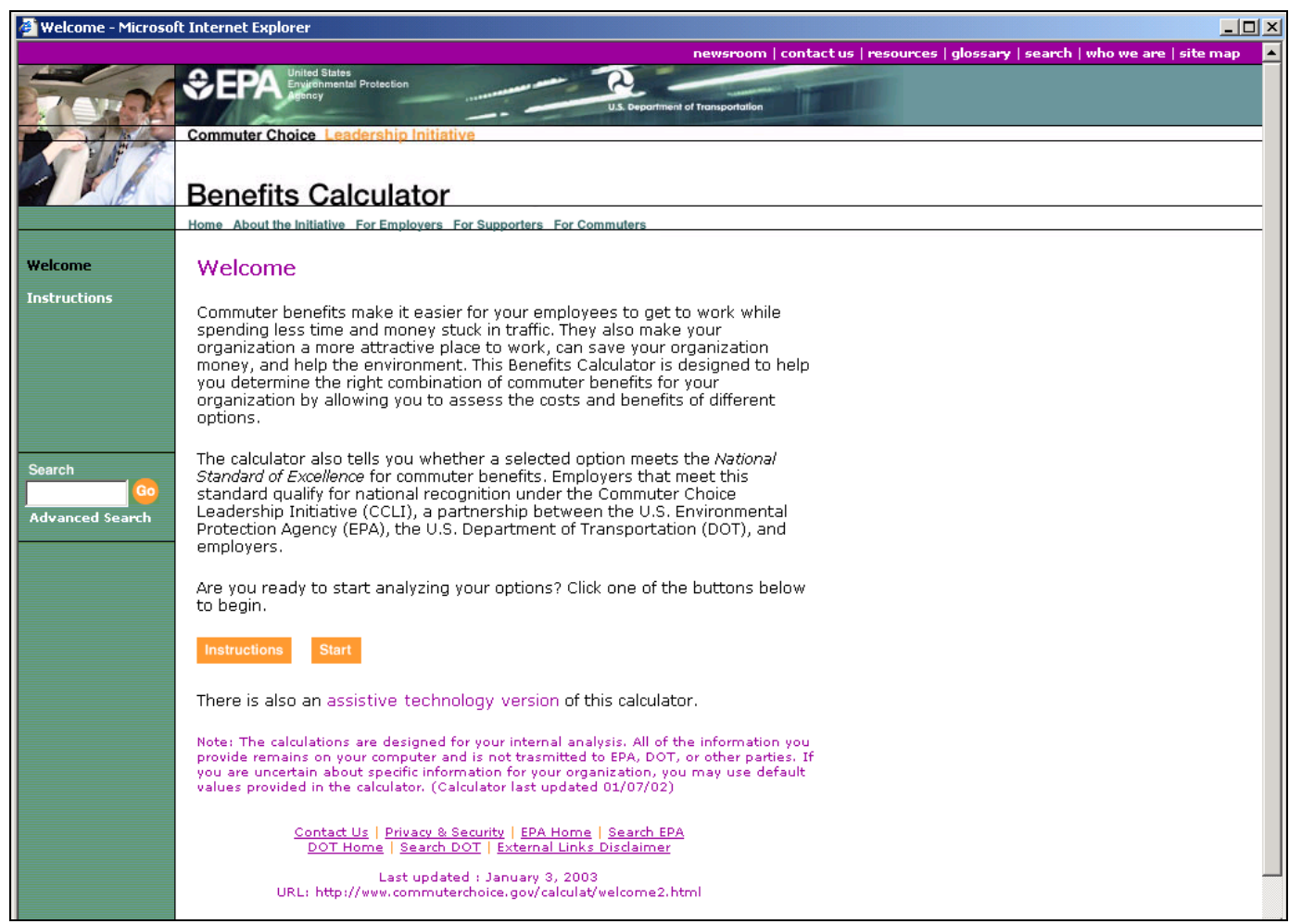

Figure 2. Business Benefits Calculator Welcome Screen.

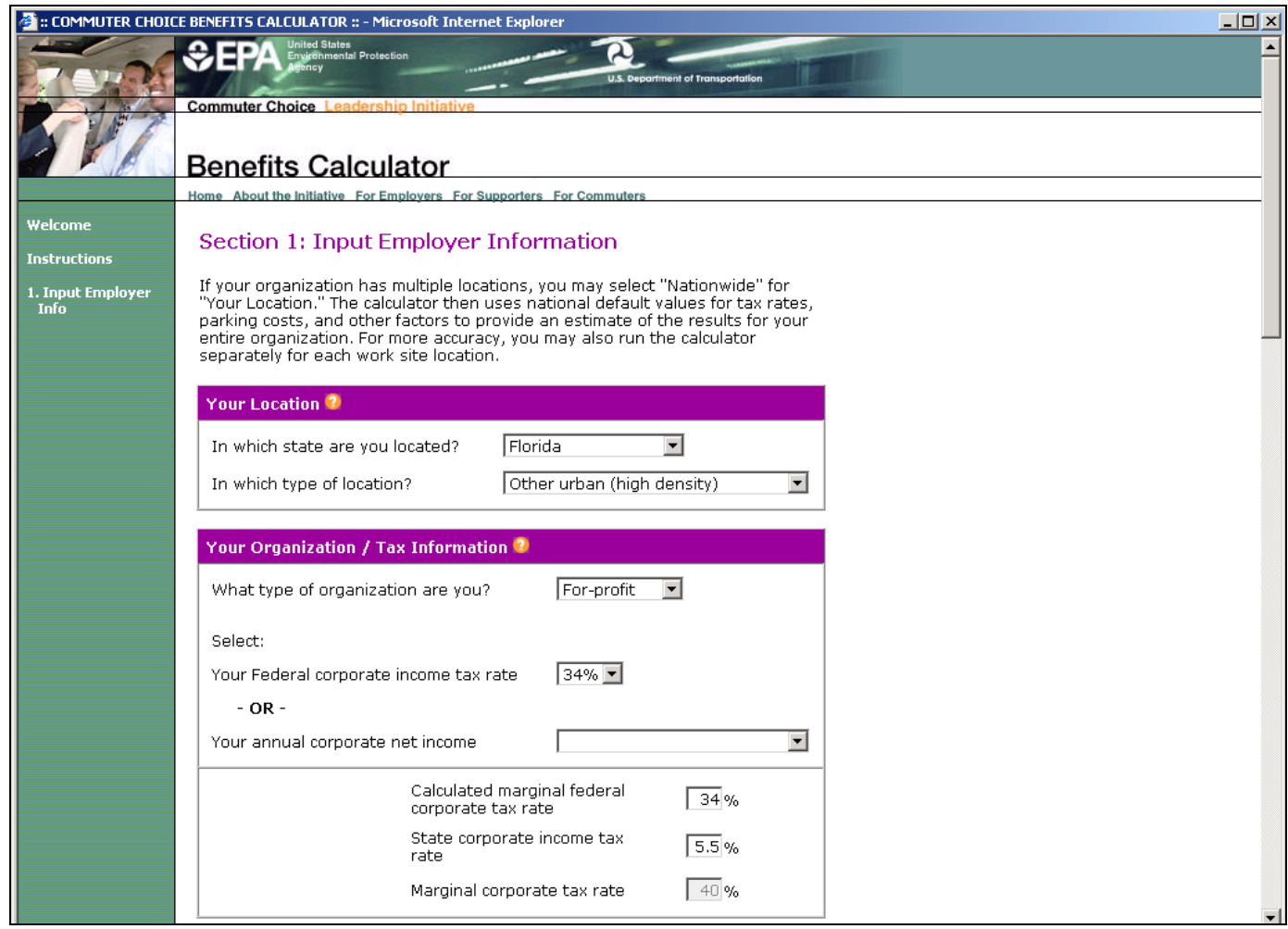

Figure 3. Business Benefits Calculator Input Employer Information Screen. 
Similarly, employees may also received reductions in payroll taxes for participating in either pre-tax and/or transit/vanpool subsidy program. Information is collected about the average employee salary and the share of employees who make less than $\$ 84,900$. The $\$ 84,900$ per year was the limit where the federal government stops collecting FICA from employees and the matching by employers. In May 2003, the limit was raised to $\$ 87,000$, retroactive to January.

One of the limiting factors of this tool is need to use average salaries. The distribution of salaries may yield different benefits for employers with the same number of employees and same total payroll (e.g., Company A with a few highly paid employees with numerous low-paid employees versus Company B with a lower standard deviation).

Parking costs are a major factor in mode choice decisions by employees. The BBC seeks to identify the amount, form of payment (e.g., pre-tax or not), and the level of employer subsidy. Changes to the cost of parking, for example, are used in the COMMUTER Model to calculate changes in mode choice. BBC developers estimated changes in travel - and parking - behavior for the BBC using the COMMUTER Model. The BBC look-up tables were based on the evaluation of ten strategies for three types of locations (CBD, urban, and suburban). In addition, two financial incentive strategies (transit/vanpool benefits and parking cash out) were analyzed in $\$ 10$ increments up to $\$ 100$ per month. For inclusion into the $\mathrm{BBC}$, the impacts were reported for total vehicle trip reductions, as well as transit/vanpool increase (used to calculate total taking advantage of transit/vanpool benefits) and bicycle/pedestrian increase. ${ }^{17}$

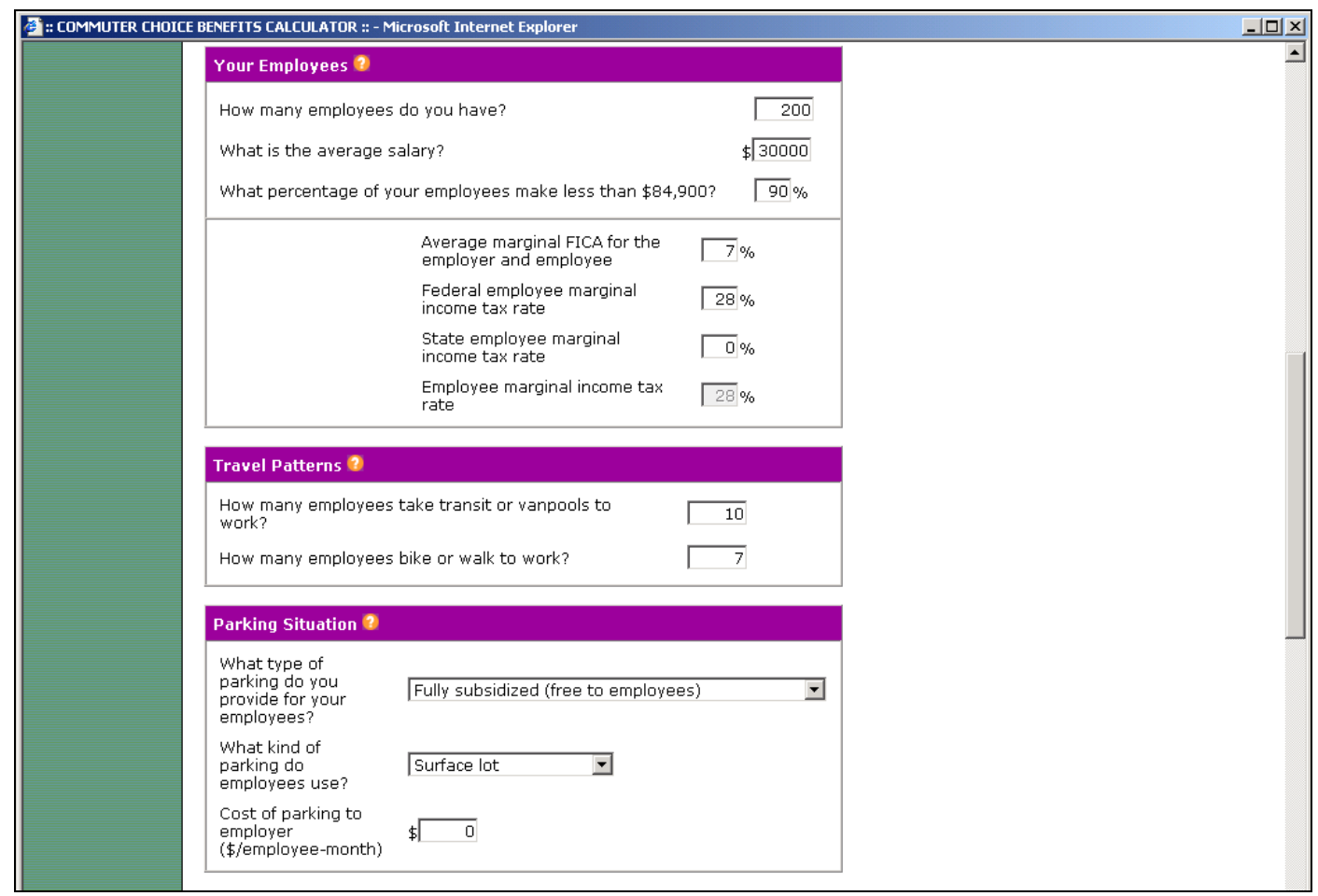

Figure 4. Business Benefits Calculator Input Employer Information Screen.

\footnotetext{
${ }^{17}$ Personal communication. Michael Grant, ICF Consulting
} 
Employers must select at least one primary benefit options and at least three supporting benefit options in order to meet the National Standard of Excellence in commuter benefits and qualify for the Commuter Choice Leadership Initiative (CCLI). Employers must also offer access to a Guaranteed Ride Home program and meet a 14\% target for the share of employees that do not drive alone to work to qualify as a CCLI employer. The next entry screen (Figures 5 and 6) is designed to allow the employer to pick strategies to implement as well as inform them of the requirements of CCLI.

The required benefits to meet National Standard of Excellence are:

- Guaranteed ride home

- Employer-paid Transit/Vanpool Benefits where the employer provides at least $\$ 30$ per month in benefits or the full value of commuting costs

- Parking Cash Out where the employer provides the option of cash instead of parking. CCLI requires the employer to offer at least $\$ 30$ per month and at least $75 \%$ of the actual saved costs of parking to classify this option as a primary benefit.

- Telecommuting as a primary benefit requires the employer to meet or exceed a $6 \%$ average participation rate as expressed as the percent of employees telecommuting on an average day (e.g., 10\% of employees who telecommute an average of 2 days per week would not meet the standard)

- Employer-defined Benefit Program is a designed to allow employers to suggest that other strategies allow them to achieve the standards. Employers must achieve demonstrable benefits the Federal Commuter Choice Team must agree if this option is to qualify as the primary benefit. 


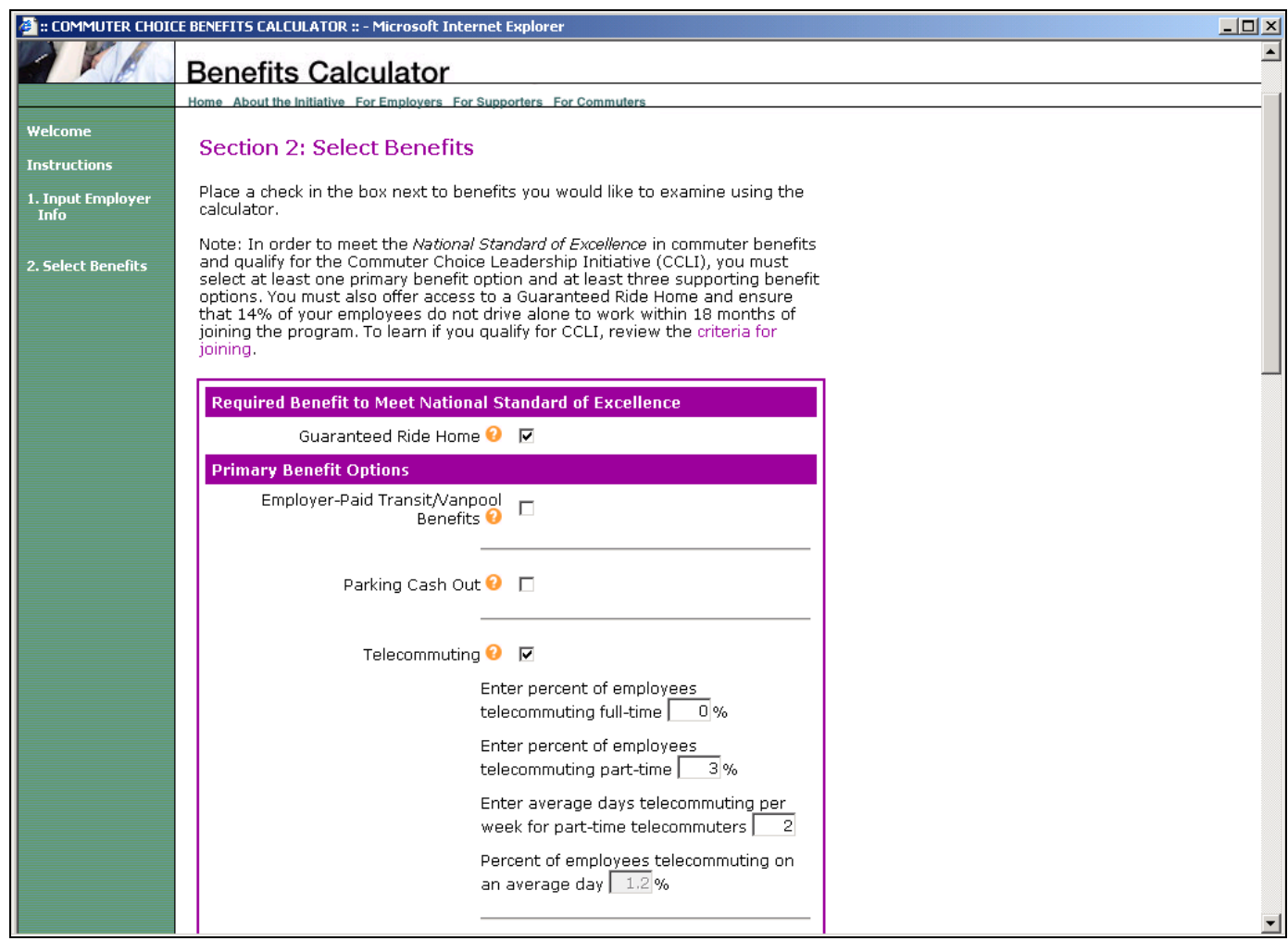

Figure 5. Business Benefits Calculator - Select Benefits Screen.

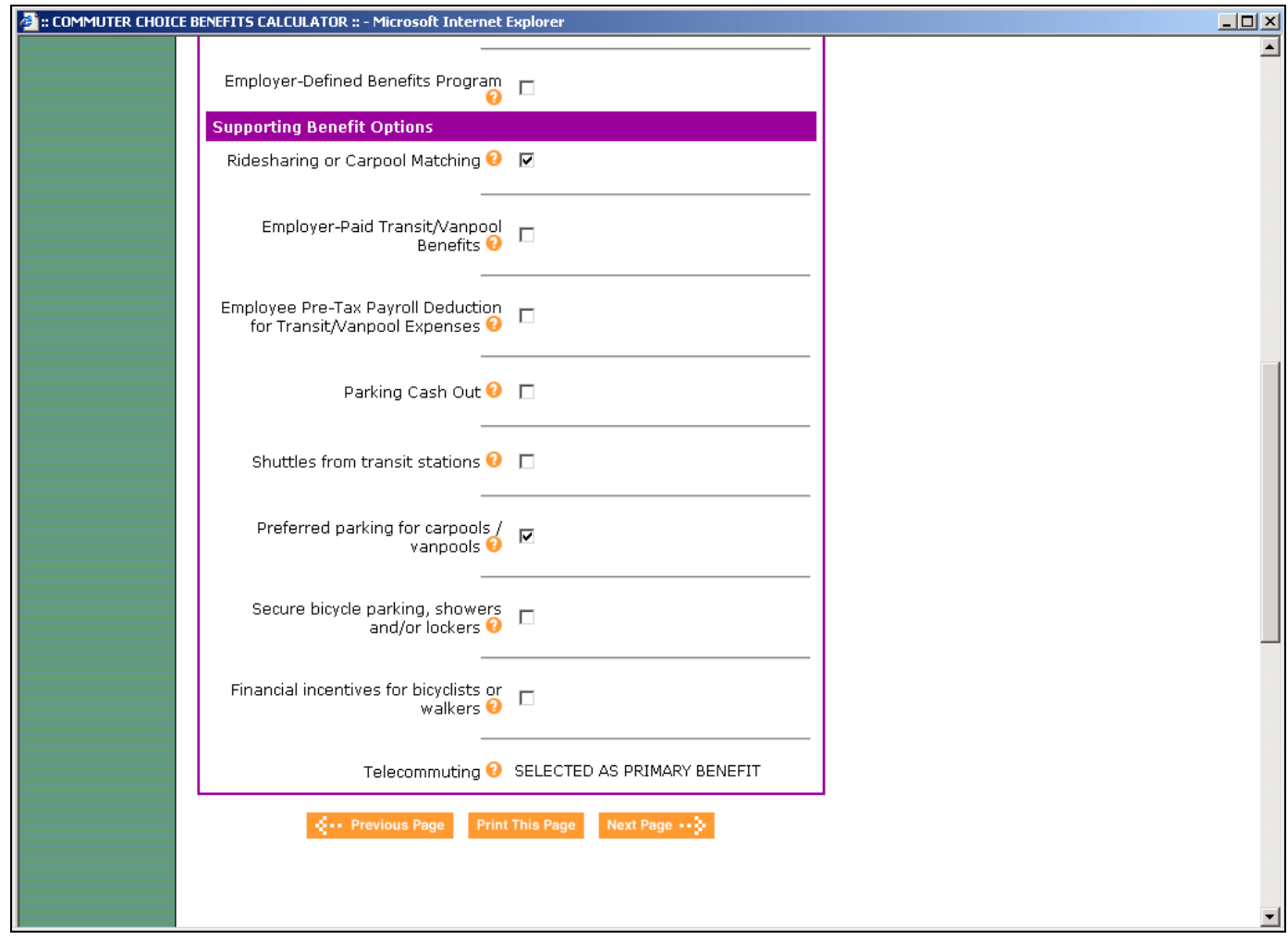

Figure 6. Business Benefits Calculator - Select Benefits Screen (cont.). 
Many of the other traditional TDM programs (e.g., ridematching, preferential parking for carpools) are treated as supporting benefit options for the purposes of CCLI but do contribute to changes in travel behavior. In addition, programs that don't meet the minimum investment criteria such as employer-paid transit/vanpool benefits where there are less than $\$ 30$ per month in benefits are treated as supporting programs. If the strategy is selected as a primary benefit, it may not be selected as a supporting program.

The other supporting programs include:

- Ridesharing or carpool matching

- Shuttles from transit stations

- Preferred parking for carpools / vanpools

- Secure bicycle parking, showers and/or lockers

- Financial incentives for bicyclists or walkers

Employers are then asked to estimate participation of employees with the introduction of the new program(s). A range of participation is estimated based on the employer's own inputs based on values in the COMMUTER Model that are hard-coded into the BBC. These ranges are shown in grayed-out boxes. The employer has the ability to override these values.

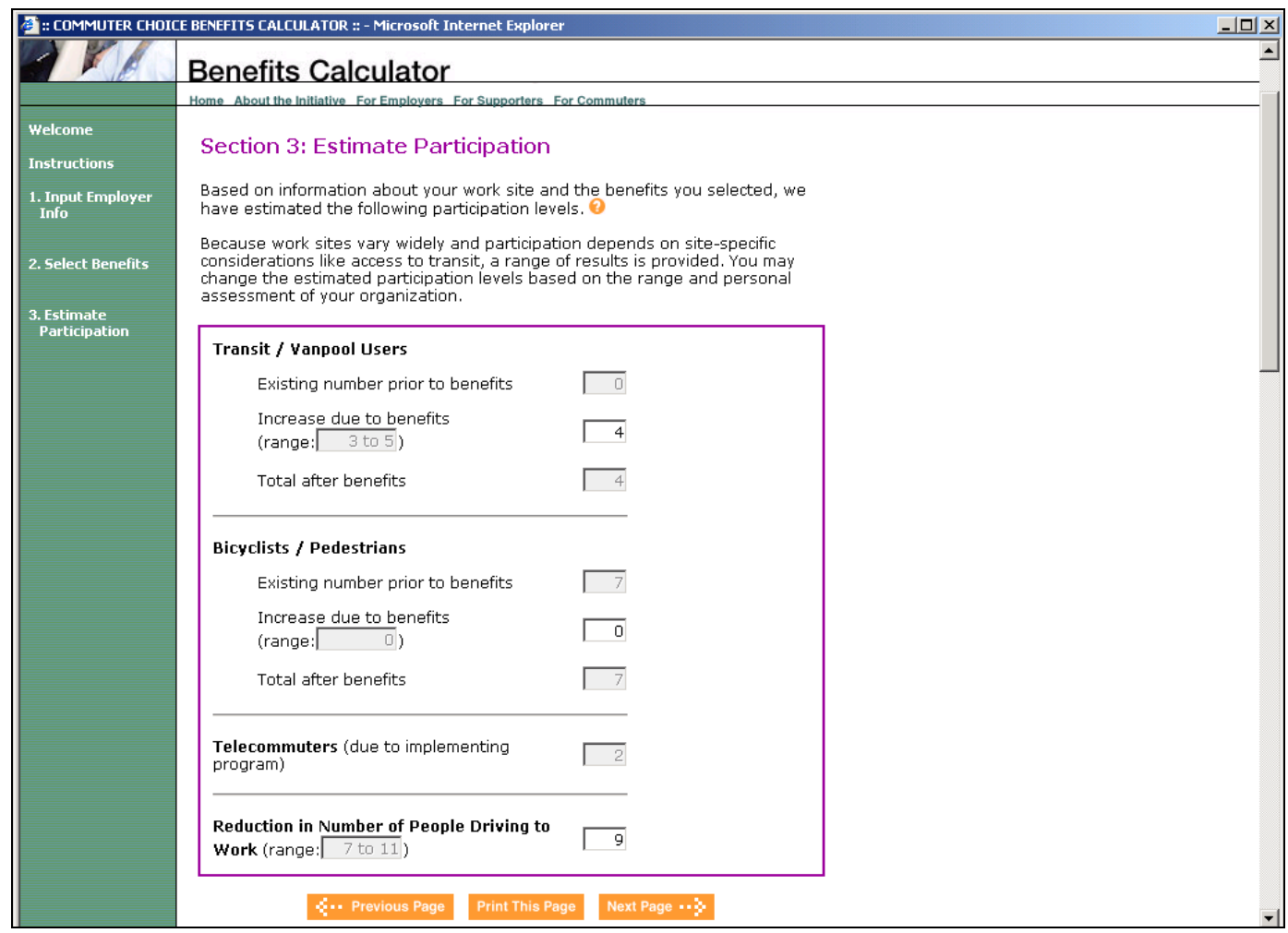

Figure 7. Business Benefits Calculator - Participation Estimation Screen. 
Based on these inputs, the Business Benefits Calculator estimates how travel behavior would change upon implementing the commuter benefit programs selected by the employer.

However, one of the COMMUTER Model's and the calculator's limitations is the assumption that the employer started with no commuter programs. In other words, it treats all of the programs as brand new. Many employers have one or more of these programs in place. If the assumption is made that COMMUTER Model accurately predicts changes in behavior, then the calculations may inflate the benefits. However, the use of ranges of impacts was a reasonable trade-off between simplicity and accuracy (at least accurate in comparison to the same program analyzed in the COMMUTER Model itself).

In recognition of this limitation, the $\mathrm{BBC}$ advises organizations that already have a commuter benefit program to use the low end of the range to represent the change in use for a particular mode or strategy. According to the documentation, the estimated range was developed by examining program scenarios for employers in different types of metropolitan areas.

After entering in the above information, the employer can view the results in the form of an easy-to-read summary. The summary provides an overview of the total annual costs and benefits, the direct costs and savings to the employer and employees, facility savings, recruitment and productivity benefits, and community impacts such as the change in emissions.

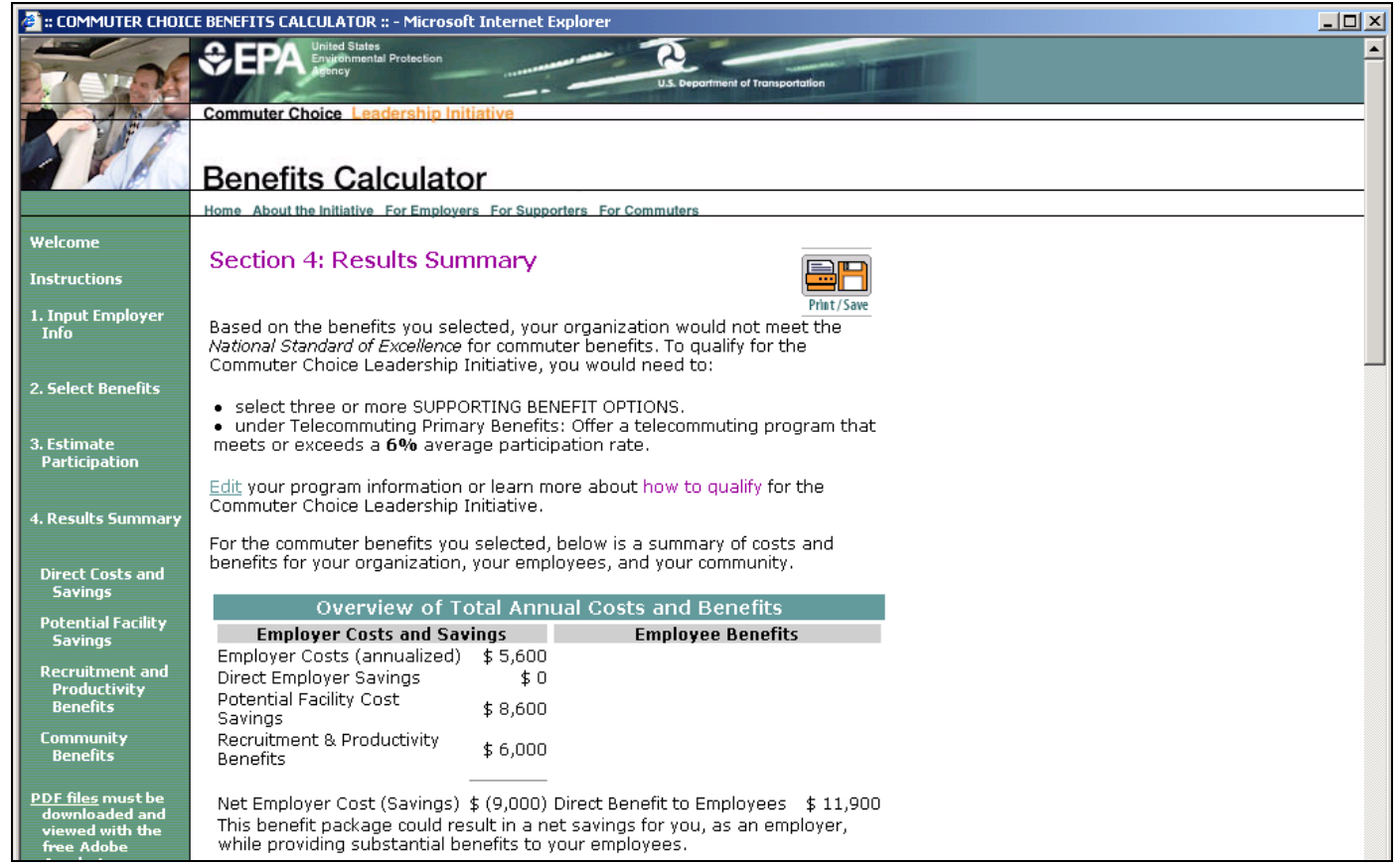

Figure 8. Business Benefits Calculator - Results Summary Screen. 


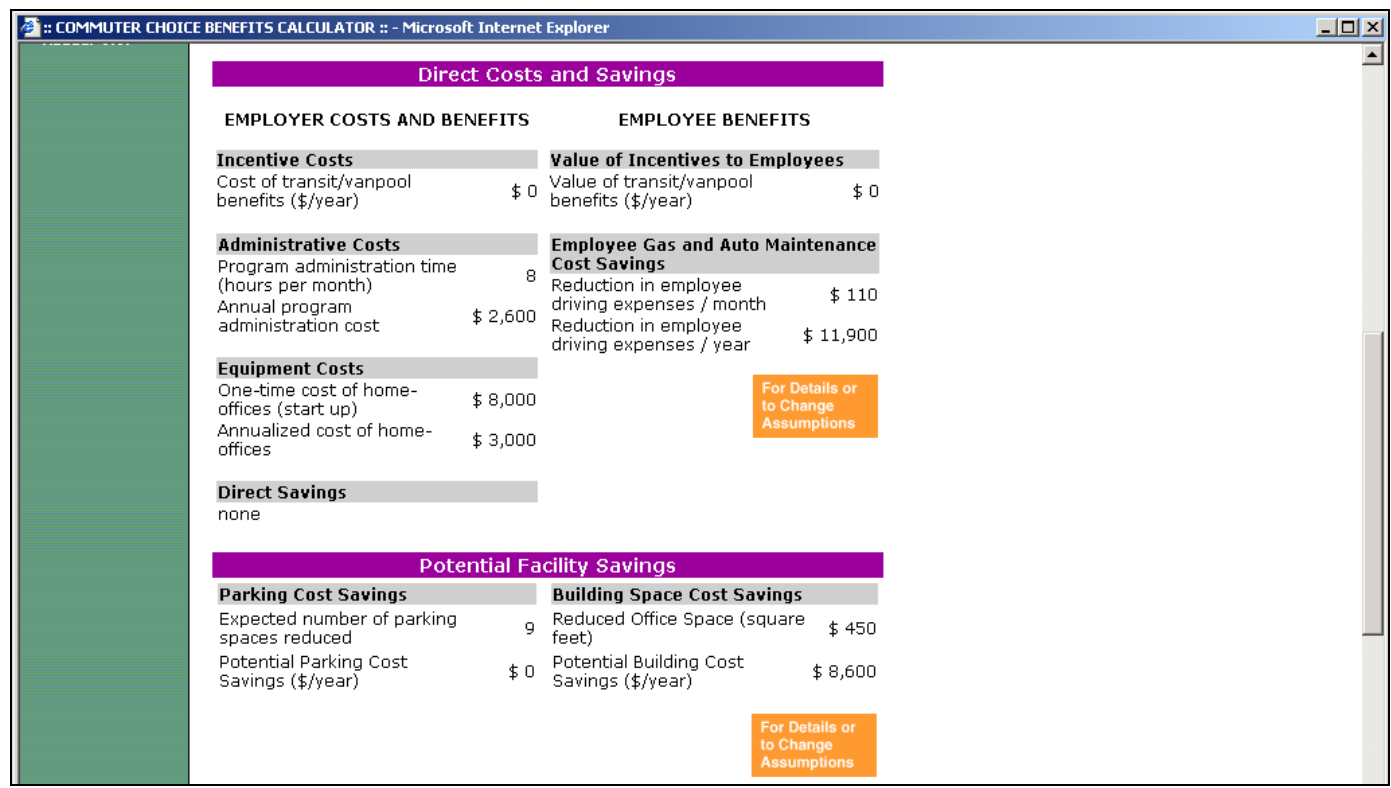

Figure 9. Business Benefits Calculator Input Employer Information Screen.

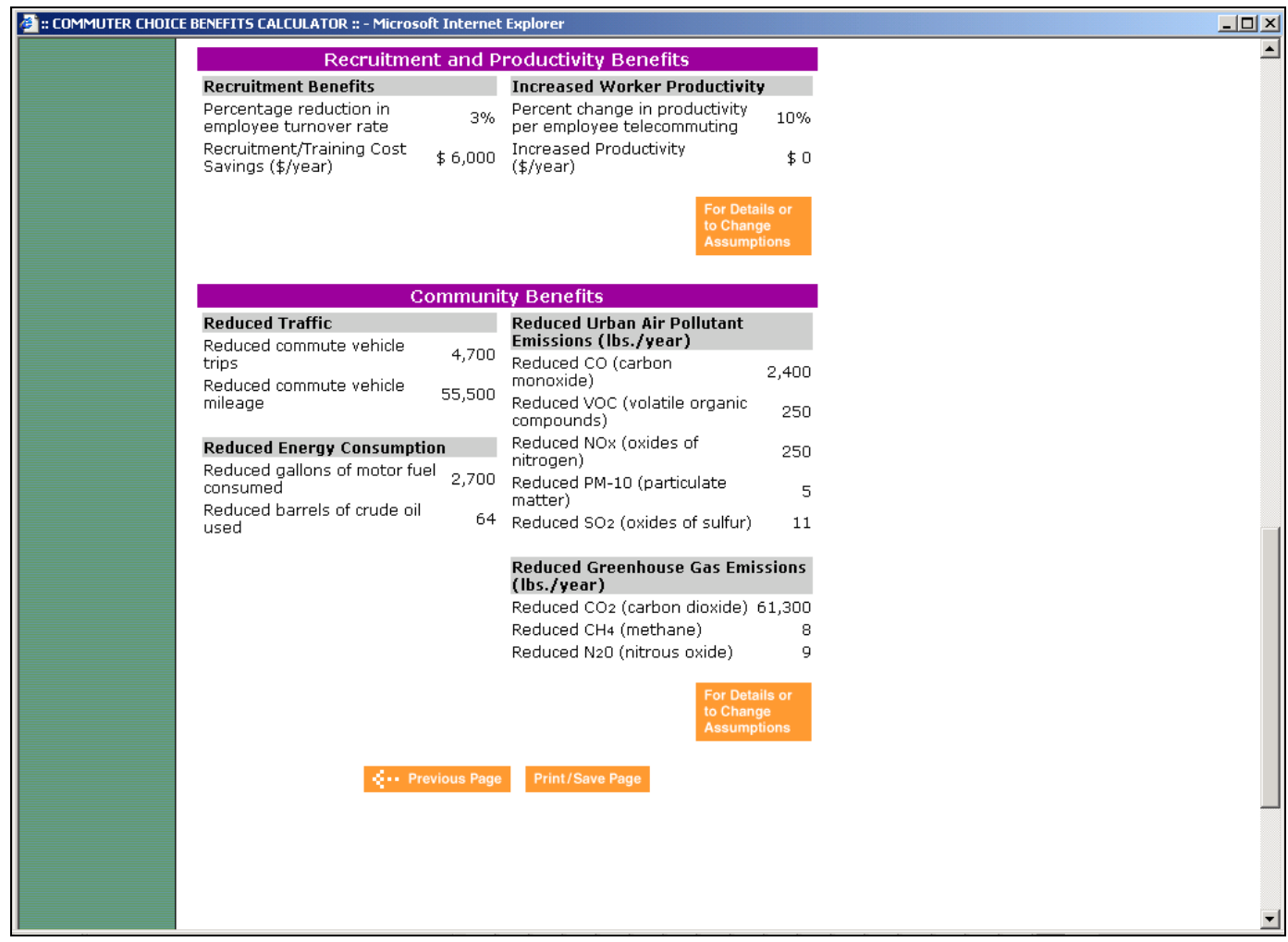

Figure 10. Business Benefits Calculator Input Employer Information Screen. 
The aforementioned savings depends on some fundamental assumptions regarding everything from administrative time spent managing the various programs to current gas prices to the dollar value of employee retention. The following summarizes some of the assumptions as documented in the BBC. The next chapter will provide some guidance in refining some of these values (e.g., the cost of turnover) that may significantly increase the benefits calculated by the BBC.

\section{Administrative Time Estimates}

$\mathrm{BBC}$ notes that the time to administer a program can vary considerably depending on employer size and the way programs are administered. For example, the range of time to administer a commuter benefits program (i.e., enroll employees and distribute passes or vouchers) ranged from only hour per month to a full-time position at 40 hours per week. ${ }^{18}$ The calculator default is set at 8 hours per month to administer a program with transit/vanpool benefits. Time could be greater or less depending on the number of employees, number of office locations, and whether administration is outsourced. The calculator default value for administering other TDM programs is set at 4 hours per month though geographic and organizational factors will also affect this value.

\section{Employee Gas and Auto Maintenance Cost Savings}

Multiplying the average cost of driving per mile by the expected number of miles reduced by employees results in the reduction in driving expenses among employees. Estimated gasoline costs and other vehicle operating-related costs (oil, maintenance, tires, and permile vehicle depreciation) are used to calculate the per-mile driving costs. Vehicle ownership costs, such as vehicle financing, insurance, license, registration, taxes, and annual depreciation are not included in this figure.

\section{Parking Cost Savings}

The expected reduction in employees driving to work daily multiplied by the average cost per space is used to calculate the parking savings. BBC adds "Since [employer-paid] parking expenses are deducted from corporate income [as a business expense] when calculating corporate income taxes, when an employer reduces parking, it saves the cost of the parking minus the corporate income tax savings associated with the parking space."

\section{Office Space Cost Savings}

Office space cost savings are solely attributable to telecommuting by the BBC. Compressed work week programs, for example, are not figured into the savings. The reduction in office space is calculated by multiplying the number of employees who telecommute full-time by the average space used per employee. This figure is then multiplied by the estimated cost per square foot, which the user can change, to estimate

\footnotetext{
18 "Strategies for Increasing the Effectiveness of Commuter Benefits Programs" Transit Cooperative Research Program Report 87, Washington DC 2003 p.94-95
} 
total cost savings. Apparently, the BBC does not make any adjustment for deductibility of rental expenses in the calculation of the benefit. The calculator also assumes homebased telework. It does not account for leasing space at telecenters.

\section{Recruitment/Retention Benefits}

Recruitment and training costs per employee are estimated at one-third of the average reported salary. The next chapter will provide a means of estimating the average cost of turnover. Generally, the costs of turnover approximate the annual cost of the departing employee. The calculator assumes a reduction in turnover from 1 to 3 percent depending on programs selected though the direct relationship between given strategies is not wellestablished.

\section{Increased worker productivity}

The BBC assumes productivity increases around 10 to 20 percent based on studies of telecommuting. Some employers may be skeptical of the productivity benefits of telecommuting since there are also some potential losses in productivity due to reduced personal interaction with co-workers.

Based on these findings, the calculator uses a default value of 10 percent productivity improvement for full-time telecommuters. The calculator assumes no productivity improvement with other commuter benefits since empirical data on these effects are not available.

\section{Reduced Vehicle Miles of Travel}

The number of vehicle miles reduced is calculated by multiplying the estimated number of vehicle trips reduced by the average vehicle trip length.

\section{Reduced Fuel Consumption}

Fuel consumption is calculated by dividing the number of vehicle miles traveled by the average miles per gallon of the U.S. fleet, 20.4 miles per gallon.

\section{Reduced Urban Air Pollutant Emissions and Reduced Greenhouse Gas Emissions}

Air pollutant emissions are estimated by multiplying the number of vehicle miles reduced by emission factors (in grams per mile) that represent national fleet averages. Actual emission reductions would vary based on location due to temperature, fuel standards, and the mix of the vehicle fleet, among other factors.

Carbon dioxide emissions are calculated by multiplying fuel consumption by factors to estimate carbon dioxide. Other greenhouse gas emissions are estimated by multiplying the number of vehicle miles reduced by emission factors that represent national fleet averages. 


\section{Commuter Choice Decision Support System}

One of the newest tools is the Commuter Choice Decision Support System (CCDSS) http://www.ops.fhwa.dot.gov/PrimerDSS/index.htm by the Federal Highway

Administration. As stated in the companion document, this tool is targeted to "Employers that are trying to determine if a commuter program would be worthwhile for their site can use the CCDSS to determine potential benefits of a specific program. An employer who has already decided to start a program but is not sure what options to implement can use the CCDSS. By entering information about the worksite into the CCDSS, employers can obtain recommendations on specific strategies that may work best for their situation." 19

The CCDSS recommends commute options "most appropriate" for the employer's needs, provides tips on how to get started and offers examples of effective strategies. This program advisor uses a simple checklist approach to gather information on employer motivations for implementing a TDM program, worksite characteristics and level of management support to recommend the top 5 options for the employer to implement from the following list:

1. Advanced route planning

2. Alternative work schedules

3. Bicycling and walking programs

4. Carpooling incentives

5. Financial incentives

6. Flexible work hours for employees

7. Live near your work programs

8. On-site employee services

9. Parking management

10. Real-time commuter services

11. Teleworking options for employees

12. Transit options and incentives

13. Vanpooling incentives

14. Worksite location and design

No impacts (e.g., benefits accrued to business or vehicle trips reduced) are calculated by CCDSS. It is intended to quickly point the employer to the strategies that would appear to make the most sense for the employer based on the issues identified by the employer and their self-reported situation.

The perceived employer benefits or issues listed in CCDSS are:

1. Improve ability to recruit appropriate employees

2. Increase employee retention / lower employee turnover

${ }^{19}$ Commuter Choice Primer: An Employee's Guide to Implementing Effective Commuter Choice Programs. Federal Transit Administration, Federal Highway Administration and Environmental Protection Agency. Washington, DC 2003 http://www.itsdocs.fhwa.dot.gov/JPODOCS/REPTS_PR/ccp/CommuterChoicePrimer.pdf 
3. Increase employee productivity and reduce tardiness

4. Improve employee morale

5. Ease transition or move to relocated worksite

6. Reduce the need for facility expansion or relocation

7. Reduce the demand for parking

8. Enhance corporate image / be seen as a community leader

9. Reduce operating costs such as parking

10. Reduce tax burden

11. Want to update or enhance emergency preparedness plan

12. Need to comply with environmental or development requirements

13. Improve industry competitiveness

CCDSS recognizes that the unique characteristics of the worksite and organization will affect how employees commute to work. Information is collected with respect to worksite location, level of transit service and congestion frequency. CCDSS probes for information about the access to options such as whether the location is in pedestrian and friendly area. Recognizing the fact that some strategies won't work without adequate facilities such as clothes lockers, showers, and/or bike storage facilities at the worksite for employees who choose to walk or bike to work. CCDSS also inquires whether there are nearby services where employees can eat, shop, bank, and conduct other personal business during lunch without having to use a personal car.

Based on the experience of the CCDSS developers, the CCDSS implies that the strategies selected should take into account several variables. These variables include the type of employer, the number of employees at the site, distribution of employees around the worksite, the relative mode split (not actual numbers but "most or few", etc.) and parking situation. Employer policies are also considered such as the work hours at this site for the majority of employees, degree employees require their own vehicle for business, and whether or not the worksite includes jobs that would be feasible to conduct at home or other remote locations.

Finally, the CCDSS inquires as to the relative importance of commuting issues to the organization's management. It queries the employer as to management's willingness to consider options to encourage employees to participate in a TDM program. For example, employers are asked if management consider purchasing equipment for new services (such as purchasing equipment for employees to work from home, paying for shuttle services, etc.) Provide financial incentives to employees (such as subsidizing the cost of transit passes or vanpool fares, reimbursing costs for employees to set up a home office, etc.)

The CCDSS is an easy to use web tool to quickly identified the strategies deemed most appropriate. As previously stated, it neither calculates the benefits or outcomes from these strategies nor estimates the costs of implementing these strategies. 


\section{CUTR_AVR - Worksite Trip Reduction Model}

Using the results of research conducted previously for the Florida Department of Transportation, CUTR develop a model to predict change in average vehicle ridership (AVR) and its inverse, vehicle trip reduction (VTR) rate. ${ }^{20}$ Unlike the COMMUTER model, CUTR_AVR was built and validated based actual plans. It used more than 8,000 before and after employer trip reduction plans from Los Angeles, Tucson and Phoenix areas to build the model. ${ }^{21}$

The model uses mode split information but only requires five incentives even though many others were examined. Picking the right input variables is critical to model development. A good subset of variables can substantially improve the performance of the model. The challenge is finding ways to select a good subset of variables to predict the change in average vehicle ridership while keeping the number input variables to a manageable level. The neural network software used to build the model uses a genetic algorithm that selects the variables. This algorithm is looking for sets of inputs (e.g., site characteristics and incentives) that act in a synergistic manner as good predictors of the output (i.e., change in AVR) rather than predicting the impact of every potential variable. The algorithm begins with population of random variable sets of limited size. As the algorithm progresses, the size of these variable sets will tend to increase if the problem requires larger data sets.

The idea of discarding potential substantial number of variables is sometimes hard to accept. It may seem unrealistic that only five TDM incentives can impact employee choice of how to commute. However, there are plausible reasons for their exclusion by the algorithm.

Some incentives that might seem effective, or even absolutely necessary for an effective TDM program, may not appear as input variables in the model. Some incentives such as marketing materials and Employee Transportation Coordinators (ETCs) were common to most companies in the data used to build the model. Thus their power to explain change in AVR was lost if nearly every plan had such an incentive. However, the fact that these types of incentive were not used in the model does not mean that the tactics aren't necessary. It is essential that marketing materials and ETCs be put in place to support ongoing TDM programs, to improve awareness and understanding of any of the other incentives. So few companies may have offered other incentives such as facility improvements that it was impossible to accurately determine their impact.

Unlike the COMMUTER Model, CUTR_AVR treats the existence of an employerprovided financial subsidy as a dummy variable - it was either offered or not. One of the

\footnotetext{
${ }^{20}$ CUTR_AVR model and users manual are available for download at www.cutr.usf.edu/tdm/download.htm

${ }^{21}$ Winters, Philip L. Francis Cleland, Mark Burrs, Rafael Perez, and Michael Pietrzyk. "Neural Network Application for Predicting the Impact of Trip Reduction Strategies". Center for Urban Transportation Research. University of South Florida. Tampa, FL February 1998.
} 
reasons for the treatment of this financial incentive was the lack of information about the incentive contained in the various data sets. In addition, the extent of financial incentives offered by companies was likely constrained by the federal tax code (i.e., employers were less likely to offer more than the nontaxable amount allowed by the Internal Revenue Services. Tax-free transit subsidies were limited to $\$ 15$ to $\$ 21$ per month for all plans and any vanpool subsidy was subject to tax prior to 1993. It is assumed that when the variable indicating a financial subsidy is offered that it is at least $\$ 15$ to $\$ 21$ per month per employee using the incentive. Subsidies offered for multiply modes (e.g., transit, vanpool, etc.) could be expected to make a larger impact than the same subsidy for a single mode.

The model was used to develop the following table based on employer-provided incentives for a "typical" employer. The mode split for Scenario 1 closely replicates the mode split for Miami-Dade County in 2000.

Table 7. Vehicle Trip Reduction - Scenario: Company with 200 employees and existing vehicle trip rate of 82.7 vehicles per 100 employees

(74\% drive alone, $14.5 \%$ carpools, $5 \%$ transit, $1.5 \%$ bike, $2 \%$ walk and $3 \%$ telecommute/compressed work week. 17\% commute over 40 minutes)

\begin{tabular}{|c|c|c|c|c|c|c|c|}
\hline & Emplox & $\begin{array}{l}\text { yer-Provided I } \\
(1=\text { Yes, } 0=\text { No }\end{array}$ & ncentive & & & & \\
\hline $\begin{array}{c}\text { parking } \\
\text { cost for } \\
\text { people who } \\
\text { drive alone }\end{array}$ & $\begin{array}{l}\text { Guaranteed } \\
\text { Ride Home }\end{array}$ & Ridematching & $\begin{array}{l}\text { Alternative } \\
\text { Mode } \\
\text { Subsidies }\end{array}$ & $\begin{array}{l}\text { Compressed } \\
\text { Work Week }\end{array}$ & \begin{tabular}{|c||} 
Vehicle \\
Trip Rate \\
Prediction
\end{tabular} & $\begin{array}{l}\text { Change in } \\
\text { Vehicle } \\
\text { Trip Rate }\end{array}$ & $\begin{array}{c}\text { Total } \\
\text { Vehicle } \\
\text { Trips } \\
\text { Reduced }\end{array}$ \\
\hline 1 & 1 & 1 & 1 & 1 & 78.7 & 4.0 & 8.1 \\
\hline 1 & 0 & 1 & 1 & 1 & 79.1 & 3.7 & 7.3 \\
\hline 1 & 1 & 1 & 0 & 1 & 79.1 & 3.6 & 7.2 \\
\hline 1 & 1 & 0 & 1 & 1 & 79.2 & 3.5 & 7.1 \\
\hline 1 & 1 & 1 & 1 & 0 & 79.2 & 3.5 & 7.1 \\
\hline 1 & 0 & 0 & 0 & 0 & 79.3 & 3.4 & 6.8 \\
\hline 1 & 0 & 1 & 0 & 1 & 79.3 & 3.4 & 6.8 \\
\hline 1 & 0 & 0 & 1 & 1 & 79.4 & 3.3 & 6.6 \\
\hline 1 & 0 & 1 & 0 & 0 & 79.4 & 3.3 & 6.6 \\
\hline 1 & 0 & 1 & 1 & 0 & 79.4 & 3.3 & 6.6 \\
\hline 1 & 1 & 0 & 0 & 1 & 79.5 & 3.2 & 6.4 \\
\hline 1 & 1 & 1 & 0 & 0 & 79.5 & 3.2 & 6.4 \\
\hline 1 & 0 & 0 & 0 & 1 & 79.6 & 3.2 & 6.3 \\
\hline 1 & 1 & 0 & 1 & 0 & 79.6 & 3.2 & 6.3 \\
\hline 1 & 0 & 0 & 1 & 0 & 79.6 & 3.1 & 6.2 \\
\hline 1 & 1 & 0 & 0 & 0 & 79.7 & 3.0 & 6.1 \\
\hline 0 & 1 & 1 & 1 & 1 & 80.7 & 2.0 & 4.0 \\
\hline 0 & 0 & 1 & 1 & 1 & 81.0 & 1.7 & 3.4 \\
\hline 0 & 1 & 0 & 1 & 1 & 81.2 & 1.5 & 3.1 \\
\hline 0 & 1 & 1 & 0 & 1 & 81.2 & 1.5 & 3.1 \\
\hline
\end{tabular}




\begin{tabular}{|c|c|c|c|c|c|c|c|}
\hline & Emplo & $\begin{array}{l}\text { yer-Provided I } \\
(1=\text { Yes, } 0=\text { No }\end{array}$ & ncentive & & & & \\
\hline $\begin{array}{l}\text { parking } \\
\text { cost for } \\
\text { people who } \\
\text { drive alone }\end{array}$ & $\begin{array}{l}\text { Guaranteed } \\
\text { Ride Home }\end{array}$ & Ridematching & $\begin{array}{l}\text { Alternative } \\
\text { Mode } \\
\text { Subsidies }\end{array}$ & $\begin{array}{l}\text { Compressed } \\
\text { Work Week }\end{array}$ & $\begin{array}{c}\text { Vehicle } \\
\text { Trip Rate } \\
\text { Prediction }\end{array}$ & $\begin{array}{l}\text { Change in } \\
\text { Vehicle } \\
\text { Trip Rate }\end{array}$ & $\begin{array}{c}\text { Total } \\
\text { Vehicle } \\
\text { Trips } \\
\text { Reduced }\end{array}$ \\
\hline 0 & 1 & 1 & 1 & 0 & \begin{tabular}{|r|}
81.2 \\
\end{tabular} & 1.5 & 3.0 \\
\hline 0 & $\underline{0}$ & 1 & 0 & 1 & 81.4 & 1.3 & 2.7 \\
\hline 0 & 0 & 0 & 1 & 1 & 81.4 & 1.3 & 2.6 \\
\hline 0 & 0 & 1 & 1 & 0 & 81.4 & 1.3 & 2.6 \\
\hline 0 & 0 & 1 & 0 & 0 & 81.5 & 1.2 & 2.4 \\
\hline 0 & 1 & 0 & 0 & 1 & 81.6 & 1.1 & 2.3 \\
\hline 0 & 1 & 1 & 0 & 0 & 81.6 & 1.1 & 2.3 \\
\hline 0 & 0 & 0 & 0 & 1 & 81.6 & 1.1 & 2.2 \\
\hline 0 & $\underline{0}$ & $\underline{0}$ & 1 & $\underline{0}$ & 81.6 & 1.1 & 2.2 \\
\hline 0 & 1 & 0 & 1 & 0 & 81.6 & 1.1 & 2.2 \\
\hline 0 & 1 & 0 & 0 & 0 & 81.7 & 1.0 & 2.0 \\
\hline
\end{tabular}

Each of the above tools from the COMMUTER Model through CUR_AVR bring strengths and weaknesses as tools for estimating the impacts of TDM programs. The following chapter will provide guidance on how to estimate the costs of various strategies not adequately addressed in the aforementioned models or tools. 


\section{Chapter 3 Methodologies for Quantifying Select Business Benefits}

The first chapter described the major factors that can benefit businesses (i.e., affect the profitability of the business). It also identified the business benefits often attributed to one or more TDM strategies. The Chapter Two described several tools to measure the transportation and air quality benefits of employer TDM programs (e.g., EPA's Commuter Model). This chapter describes how to calculate select business benefits frequently cited but largely unmeasured as being associated with TDM.

While there are a variety of methods and tools for estimating impacts of TDM on vehicle trips and emissions, there is no standardized approach for measuring business benefits, in an acceptably rigorous manner. The methods used by business to estimate the costs of turnover, for example, are far less known to the public transit and TDM research communities. This chapter will provide information on how to measure the costs of turnover, absenteeism, and parking. A general introduction to a particular cost as well as available information as the current extent of use or cost will be provided. By providing detailed methods for calculating the cost or savings, the human-cost approach can be used which examines the rates and costs before the intervention is offered and comparing those rates to rates measured after the intervention is provided.

It also includes a method of calculating the savings accruing to employees and businesses for participating in the qualified transportation fringe benefit program. The detailed methods are accompanied with look-up tables to allow for quick estimates of the costs to business under a variety of scenarios.

\section{Business Benefit: Reduction in Costs of Turnover}

An organization's success depends increasingly on its ability to attract and retain employees. The need for good employees is one constant shared by all types of organizations. Businesses invest substantial resources in recruiting employees, training to improve performance and creating opportunities for continuing growth. The loss of employees or turnover can increase direct and indirect costs to the business and, therefore, consume resources. TDM strategies such as compressed workweeks, transit subsidies and teleworking are examples of TDM strategies that can decrease turnover and attract a large pool of candidates.

Changing jobs happens quite frequently. In August 2002, the Bureau of Labor Statistics examined the number of jobs that people born in the years 1957 to 1964 held from age 18 to age 36. These younger baby boomers held an average of 9.6 jobs from ages 18 to 36 . BLS defined a job as an uninterrupted period of work with a particular employer. Men 
held an average of 9.9 jobs and women held 9.3 jobs. Both men and women held more jobs on average in their late teens and early twenties than they held in their mid thirties. ${ }^{22}$

Regardless of the amount of turnover that occurs, the need to attract qualified labor is not a trivial matter and will be an increasingly difficult challenge for more businesses in the near future as the labor pool and mix continues to change. Between 2000 and 2010, total employment is projected to increase by 15 percent, slightly less than the 17 percent growth during the previous decade. For the period covering 2000-2010, BLS projects a 1.1 percent growth rate in the labor force, the same rate as in 1990-2000. However, there will be changes in the mix. For example, the 55 and older cohort will grow 3.9 percent while the 25-54 will only grow at 0.5 and the 16 to 24 will grow at 1.4 . The rate of growth of women in the labor force is expected to slow, but it will still increase at a faster rate than that of men. ${ }^{23}$ With competition for qualified employees expected to increase and the mix, strategies to attract the best candidates and to reduce employee turnover will come under more scrutiny by businesses.

One indicator that businesses see the need to be more competitive is the growing diversity of the benefit package from retirement and health benefits to subsidized commuting and flexible work place programs.

Table 8. Employer Benefits - 1999 and 2000.

\begin{tabular}{|l|r|r|}
\hline Benefit & $\mathbf{2}$ & $\mathbf{2 0 0 0}$ \\
\hline Retirement benefits & 48 & 48 \\
\hline All & 21 & 19 \\
\hline Defined benefit & 36 & 36 \\
\hline Defined contribution & & \\
\hline Health Care Benefits & 53 & 52 \\
\hline Medical care & 32 & 29 \\
\hline Dental care & 18 & 17 \\
\hline Vision care & & \\
\hline Survivor Benefits & 56 & 54 \\
\hline Life insurance & 43 & 41 \\
\hline Accidental death and dismemberment & 3 & 2 \\
\hline Survivor income benefits & & \\
\hline Disability Benefits & 53 & NA \\
\hline Paid sick leave & 36 & 34 \\
\hline Short-term disability & 25 & 26 \\
\hline Long-term disability & & \\
\hline
\end{tabular}

\footnotetext{
${ }^{22}$ Number of Jobs Held, Labor Market Activity, and Earnings Growth among Younger Baby Boomers: Results from More Than Two Decades of a Longitudinal Survey. Bureau of Labor Statistics August 2002. http://www.bls.gov/nls/nlsy79r19.pdf

${ }^{23}$ Fullerton, Jr.,Howard N and Mitra Toossi. "Employment outlook: 2000-10 Labor force projections to 2010: steady growth and changing composition." Monthly Labor Review Online. Bureau of Labor Statistics. November 2001. http://www.bls.gov/opub/mlr/2001/11/art2full.pdf
} 


\begin{tabular}{|c|c|c|}
\hline Benefit & 1999 & 2000 \\
\hline \multicolumn{3}{|l|}{ Paid Time Off } \\
\hline Paid vacations & 79 & 80 \\
\hline Paid holidays & 75 & 77 \\
\hline \multicolumn{3}{|l|}{ Employer Assistance for Child Care } \\
\hline \begin{tabular}{|l|} 
Total \\
\end{tabular} & 6 & 4 \\
\hline Employer-provided funds & 4 & 2 \\
\hline On-site child care & 3 & 2 \\
\hline Off-site child care & 2 & 1 \\
\hline Adoption assistance & 6 & 5 \\
\hline Long-term Care Insurance & 6 & 7 \\
\hline Flexible Work Place & 3 & 5 \\
\hline \multicolumn{3}{|l|}{ Non-Wage Cash Payments } \\
\hline Nonproduction bonus & 42 & 48 \\
\hline Supplemental unemployment benefits & 2 & 1 \\
\hline Severance pay & 22 & 20 \\
\hline Subsidized Commuting & 4 & 3 \\
\hline \multicolumn{3}{|l|}{ Section 125 Cafeteria Benefits } \\
\hline Total & 28 & NA \\
\hline Flexible benefit plans & 7 & $\mathrm{NA}$ \\
\hline Reimbursement plans & 15 & $\mathrm{NA}$ \\
\hline Premium conversion plans & 6 & NA \\
\hline \multicolumn{3}{|l|}{ Education Assistance } \\
\hline \begin{tabular}{|l|} 
Work-related \\
\end{tabular} & NA & 38 \\
\hline Non-work related & $\mathrm{NA}$ & 9 \\
\hline Travel Accident Insurance & $\mathrm{NA}$ & 15 \\
\hline \multicolumn{3}{|l|}{ Health Promotion Benefits } \\
\hline \begin{tabular}{|l|} 
Wellness programs \\
\end{tabular} & NA & 18 \\
\hline Fitness centers & $\mathrm{NA}$ & 9 \\
\hline
\end{tabular}

The Bureau of Labor Statistics is tracking the growth some TDM-related benefits such as working from home. BLS tracks "flexible work place" as a formal program that allows employees who would otherwise work at the establishment to work either some or their entire work schedule at home. The following table captures the proliferation of portable technologies (laptops, cell phones, wireless connections, etc.) that is allowing more professional and technical members of the workforce to literally work anywhere at any time. 
Table 9. Flexible Work Place Trends for Medium and Large Private Employers.

\begin{tabular}{|l||c|c|c|c|}
\hline & \multicolumn{4}{|c|}{ Percent } \\
All Employees & $\begin{array}{c}\text { Professional, } \\
\text { technical and } \\
\text { related }\end{array}$ & $\begin{array}{c}\text { Clerical and } \\
\text { sales employees }\end{array}$ & $\begin{array}{c}\text { Blue-collar and } \\
\text { service } \\
\text { employees }\end{array}$ \\
\hline 1995 & 2 & 5 & 2 & 1 \\
\hline 1997 & 2 & 5 & 3 & $<0.5$ \\
\hline 1999 & 3 & 7 & 3 & 1 \\
\hline 2000 & 5 & 12 & 4 & 1 \\
\hline
\end{tabular}

An organization's success depends increasingly on its ability to attract and retain employees. Businesses invest substantial resources in recruiting employees, training to improve performance and creating opportunities for continuing growth. The loss of employees or "turnover" can increase direct and indirect costs and, therefore, the need for additional resources.

The purpose of this section is to identify the positive and negative consequences of employee turnover on the individual, work group, and organization. With an understanding of the consequences, TDM agencies will be better equipped to identify linkages between business problems and TDM strategies.

In introduction to the terminology is in order. Employee turnover is the rate of employee movement into and out of the organization over a given period. There are two types of movements: additions and separations. There also are two types of separations: voluntary (employee-initiated) and other (firing, death, retirement). Voluntary separations can be further classified as avoidable or unavoidable separations. Unavoidable separations are those that the company has no control such as the job transfer of a spouse. Avoidable separations are those that the company could have prevented in some manner. Raising the pay of an employee who has another job offer or providing a transportation allowance for

\section{Case Study: Marriott Worldwide Reservations Center ${ }^{1}$}

According to David Barwick, Human

Resources Manager for Marriott Worldwide Reservations Center, 40 percent of potential recruits could not be hired due to personal transportation challenges. Efforts to improve transportation included coordinating transit schedules with MWRC's primary day shift, adding a Cobb County (Georgia) Transit bus to an existing route to accommodate late-shift workers, and extending service from $10 \mathrm{p} . \mathrm{m}$. to 11 p.m. MWRC also enrolled in Cumberland Transportation Network's TransAdvantage program for discounted bus and rail passes. Ridematching helped put over 270 workers in carpools. MWRC also offers Guaranteed Ride Home, preferential work schedules, and vacation time as incentives to use alternative transportation. As a result, MWRC's turnover decreased 87 percent, saving the company $\$ 200,000$ in 1998. The transportation program allowed them to expand from 90 employees to over 300 employees in two years. 
employees who work in a high cost area are examples of prevention techniques to address avoidable separations.

Regardless of the reason, the loss of an employee can have positive and negative consequences on the individual and organization. Potential moderating circumstances can affect the nature and extent of the consequence including the cost of turnover. For example, some jobs, especially those with a high degree of customer-contact or those at the policy-setting level, can have a significant productivity and cost impacts throughout the organization. Other jobs such as those in the fast food service industry with predictable levels of turnover or limited customer contact can be replaced with less impact.

There are numerous possible consequences facing the individual who leaves the job, each with potential moderating factors. On the positive side of leaving the job, the individual may benefit economically and/or advance a career. They also may change jobs to move closer to their current residence or seek other employment when a company relocates from one part of town to another. For the departing employee, there may be negative consequences, too. When changing a job, the individual may lose seniority and benefits such as free parking or flexible work hours. The key moderating variable for these outcomes is the difference between the jobs.

Employees who remain behind after another employee departs can also benefit. For example, the opening may create a new opportunity for advancement or improved morale. Table 10 lists some of the positive and negative consequences associated with turnover for "leavers" and "stayers". 
Table 10. Consequences of Turnover for Individuals. ${ }^{24}$

\begin{tabular}{|c|c|c|c|}
\hline \multirow[b]{2}{*}{$\begin{array}{l}\text { Level of } \\
\text { analysis }\end{array}$} & \multicolumn{2}{|c|}{ Possible Consequences } & \multirow[b]{2}{*}{$\begin{array}{c}\text { Potential moderating } \\
\text { variables }\end{array}$} \\
\hline & Positive & Negative & \\
\hline Leavers & $\begin{array}{l}\text { Increased earnings }(2,4) \\
\text { Career advancement }(2,4) \\
\text { Improved individual-job } \\
\text { match }(6) \\
\text { Increased challenge }(6) \\
\text { Self-development }(6) \\
\text { Nonwork benefits }(\text { e.g., } \\
\text { geographic location) }(6) \\
\text { Increased family ties }(3,6) \\
\text { New social relationships }(5) \\
\text { Enhanced commitment to } \\
\text { new job and organization }(6)\end{array}$ & $\begin{array}{l}\text { Loss of seniority }(1) \\
\text { Loss of nonvested } \\
\text { benefits }(1) \\
\text { Unreimbursed moving } \\
\text { costs }(2,6) \\
\text { Disruption of family } \\
(3,6) \\
\text { Transition stress }(3,6) \\
\text { Loss of friendships }(5) \\
\text { Decreased family ties } \\
(3,6)\end{array}$ & $\begin{array}{l}\text { 1. Tenure } \\
\text { 2. Labor market } \\
\text { 3. Family status } \\
\text { 4. Job skills/abilities } \\
\text { 5. Social involvement } \\
\text { in work } \\
\text { 6. Characteristics of } \\
\text { old versus new job }\end{array}$ \\
\hline Stayers & $\begin{array}{l}\text { Opportunities for promotion } \\
(8,9) \\
\text { More positive job attitudes } \\
(1,4,7,9) \\
\text { Increased performance }(3,5) \\
\text { Stimulation at work }(2,9) \\
\text { Initiation of search that } \\
\text { results in } \\
\quad \text { better job }(1,6,7)\end{array}$ & $\begin{array}{l}\text { Increased workload } \\
(3,5,6,9) \\
\text { Decreased performance } \\
(3,5,6,9) \\
\text { Stress and uncertainty } \\
(6,9) \\
\text { Less positive job } \\
\text { attitudes }(1,4) \\
\text { Loss of friendships }(2)\end{array}$ & $\begin{array}{l}\text { 1. Beliefs about why } \\
\text { others leave } \\
\text { 2. Social relationship } \\
\text { to leavers } \\
\text { 3. Task } \\
\text { interdependence } \\
\text { 4. Status of leaver } \\
\text { 5. Performance of } \\
\text { leaver } \\
\text { 6. Job market } \\
\text { conditions } \\
\text { 7. Career orientation } \\
\text { of stayer } \\
\text { 8. Level in } \\
\text { organization of leaver } \\
\text { 9. Organization } \\
\text { promotion policies }\end{array}$ \\
\hline
\end{tabular}

${ }^{a}$ The numbers following each consequence refer to potential moderating variables thought to be most closely associated with that consequence.

Ultimately, the consequences of turnover are borne by the organization. Increased effectiveness of the individual and work group translates into increased productivity and profits. At the same time, the social costs of turnover disrupt the organization's cohesiveness. Possible positive consequences arising from employee turnover on the

\footnotetext{
${ }^{24}$ Mowday, Richard T., Lyman W. Porter and Richard M. Steers. Employee-Organization Linkages: The Psychology of Commitment, Absenteeism and Turnover. New York, Academic Press, 1982
} 
organization could include increased effectiveness, new skills and abilities, and decreased conflict among employers. At the same time, disruption of the work flow to cover for departing employee and inefficiencies related to the new hire can negatively impact the organization.

If current labor market conditions make it a "buyers" market - the demand for jobs exceeds the supply then the duration and severity of the impact may not be severe. The same can be said for organizations with a strong program of advancement and a broad internal pool from which to draw replacement employees. Issues such as the difficulty of replacing the employee and characteristics of the replacement are moderating variables.

Given that there are potential benefits of turnover, why should companies worry about finding replacement workers? There are five major problems associated with new employees can be quite costly to the organization:

- Lost or dissatisfied customers

- Mistakes made and the time and expenses to correct them

- Fraud

- Shortages

- Higher overhead costs

For example, it isn't unusual to find new employees made 80 percent of the errors. High turnover, therefore, means more errors and more resources allocated to fixing the errors.

The cost of turnover can be surprising to some. Many employers think they miscalculated when they find turnover costs of $\$ 30,000$ per employee. Even though the cost can be quite high, employers may not know the cost of employee turnover because it rarely shows up as a budget line item. Its costs are distributed all along the chain. As the first chapter explains, the direct costs often are only the tip of the iceberg. Employers find most of the costs are contained in the indirect costs. One of the keys to positioning TDM strategies as potential solutions to business problems is understanding the components of turnover and providing a basis for employers to evaluate the potential impact of those strategies. Employers then can measure the costs before an intervention (e.g., transit pass subsidy) is offered and compare those cost to those measured after the intervention is provided.

There are nine components that contribute to the cost of turnover:

1. Inefficiency of the Departing Employee

2. Inefficiency of those closely associated with departing employee

3. Inefficiency of position being filled while vacant

4. Out-of-pocket processing costs

5. Human resources department processing costs

6. Processing costs of other departments

7. Relocation costs (prorated across all hires) 
8. Incoming employee inefficiency

9. Inefficiency of those closely associated with incoming employee

The following nine tables illustrate a process for calculating the cost of turnover. The values in the shaded boxes are the inputs required to estimate the cost though the actual values will vary. Table 21 totals the nine elements.

Table 11. Departing Employee Inefficiency.

\begin{tabular}{|l|r|r|r|} 
& $\begin{array}{c}\text { Weeks } \\
\text { Operating at } \\
\text { Given } \\
\text { Efficiency } \\
\text { Level }\end{array}$ & $\begin{array}{c}\text { Average } \\
\text { Efficiency }\end{array}$ & $\begin{array}{c}\text { Weeks of Full } \\
\text { Productivity } \\
\text { Efficiency Level }\end{array}$ \\
\hline $100-75 \%$ & 2.00 & $87.5 \%$ & 1.75 \\
\hline $75-50 \%$ & 1.00 & $62.5 \%$ & 0.63 \\
\hline $50-25 \%$ & 0.50 & $37.5 \%$ & 0.19 \\
\hline $25-0 \%$ & 0.50 & $12.5 \%$ & 0.06 \\
\hline Cumulative Weeks & 4.00 & & 2.63 \\
\hline Average number of weeks per month & 4.33 & & 4.33 \\
\hline Equivalent Months (Cumulative weeks/weeks & & & 0.66 \\
\hline per month) & 0.92 & & \\
\hline
\end{tabular}

Table 12. Incoming Employee Inefficiency.

\begin{tabular}{|c|c|c|c|}
\hline Efficiency Level & $\begin{array}{c}\text { Months } \\
\text { Operating at } \\
\text { Given } \\
\text { Efficiency } \\
\text { Level } \\
d\end{array}$ & $\begin{array}{c}\text { Average } \\
\text { Efficiency } \\
e\end{array}$ & $\begin{array}{l}\text { Weighted } \\
\text { Months of } \\
\text { Full } \\
\text { Productivity } \\
f=d x e^{\text {P }}\end{array}$ \\
\hline $0-25 \%$ & 1.7 & $12.5 \%$ & 0.21 \\
\hline $25-50 \%$ & 1.9 & $37.5 \%$ & 0.71 \\
\hline $50-75 \%$ & 3.5 & $62.5 \%$ & 2.19 \\
\hline $75-100 \%$ & 4.8 & $87.5 \%$ & 4.20 \\
\hline Total Months & 11.9 & & 7.31 \\
\hline
\end{tabular}


Table 13. Costs of Turnover - Inefficiency of the Departing Employee.

\begin{tabular}{|c|c|c|c|c|}
\hline & & Months & $\begin{array}{l}\text { Monthly } \\
\text { Salary } \\
\text { and } \\
\text { benefits } \\
\text { of } \\
\text { Departing } \\
\text { Employee }\end{array}$ & $\begin{array}{c}\text { Value of } \\
\text { Lost } \\
\text { Productivity } \\
\text { Due to the } \\
\text { Inefficiency } \\
\text { of the } \\
\text { Departing } \\
\text { Employee }\end{array}$ \\
\hline & & $g$ & $H$ & $j=g \times h$ \\
\hline Months before employee departs & $\operatorname{sum}(a)=$ & 0.92 & & \\
\hline $\begin{array}{l}\text { Months of full productivity before } \\
\text { employee departs }\end{array}$ & $\operatorname{Sum}(\mathrm{c})=$ & 0.66 & & \\
\hline $\begin{array}{l}\text { Value of lost productivity before } \\
\text { employee departs }\end{array}$ & $\operatorname{sum}(a)-\operatorname{sum}(c)=$ & 0.27 & $\$ 3,300$ & $\$ 881$ \\
\hline
\end{tabular}

Table 14. Costs of Turnover - Inefficiency of the Position Being Filled While Vacant.

\begin{tabular}{|c|c|c|c|c|}
\hline & $\begin{array}{l}\text { Efficiency } \\
\text { Sacrificed } \\
\text { while } \\
\text { Vacant } \\
q\end{array}$ & $\begin{array}{l}\text { Weeks Until } \\
\text { Position } \\
\text { Filled } \\
r\end{array}$ & $\begin{array}{c}\text { Weekly Salary } \\
\text { and benefits } \\
\text { of Vacant } \\
\text { Position } \\
s=h /(52 / 12)\end{array}$ & $\begin{array}{l}\text { Total Value of } \\
\text { Inefficiency of } \\
\text { Position Being } \\
\text { Filled While } \\
\text { Vacant } \\
t=q x r x s\end{array}$ \\
\hline $\begin{array}{l}\text { Position efficiency } \\
\text { sacrificed while vacant }\end{array}$ & $67 \%$ & 10 & 762 & 5,102 \\
\hline & Hours & \begin{tabular}{|c|}
$\begin{array}{c}\text { Weeks Until } \\
\text { Position } \\
\text { Filled }\end{array}$ \\
\end{tabular} & \begin{tabular}{|l|} 
Hourly \\
Salary and \\
Benefits \\
\end{tabular} & \\
\hline $\begin{array}{l}\text { Coverage for Vacant } \\
\text { Position (Regular Hours) }\end{array}$ & $u$ & $v=r$ & $w=m /(20 \times 8)$ & $y=u \times v \times w$ \\
\hline Supervisor & 2 & 10 & $\$ \quad 31.25$ & $\$ \quad 625$ \\
\hline Staff & 10 & 10 & 17.50 & 1,750 \\
\hline \begin{tabular}{|l} 
Support Staff \\
\end{tabular} & 10 & 10 & 9.38 & 938 \\
\hline $\begin{array}{l}\text { Coverage for Vacant } \\
\text { Position (Overtime Hours) } \\
\text { (assume paid at } 1.5 \text { hours } \\
\text { for every } 1 \text { hour overtime) }\end{array}$ & & & & \\
\hline Staff & 1 & 10 & 26.25 & 263 \\
\hline Support Staff & 2 & 10 & 14.06 & 281 \\
\hline & & & & 8,959 \\
\hline
\end{tabular}


Table 15. Costs of Turnover - Out-of-Pocket Processing Hiring Costs.

\begin{tabular}{|c|c|c|}
\hline & \multicolumn{2}{|c|}{$\begin{array}{c}\text { Direct Expenses } \\
\mathrm{z}\end{array}$} \\
\hline Agency search fees & $\$$ & - \\
\hline Outplacement fees & $\$$ & - \\
\hline Advertising costs & $\$$ & 500 \\
\hline $\begin{array}{l}\text { Travel costs for recruiters and } \\
\text { candidates }\end{array}$ & $\$$ & 750 \\
\hline Other & $\$$ & 125 \\
\hline Total & $\$$ & 1,375 \\
\hline
\end{tabular}

Table 16. Costs of Turnover - Human Resource Department Processing Costs.

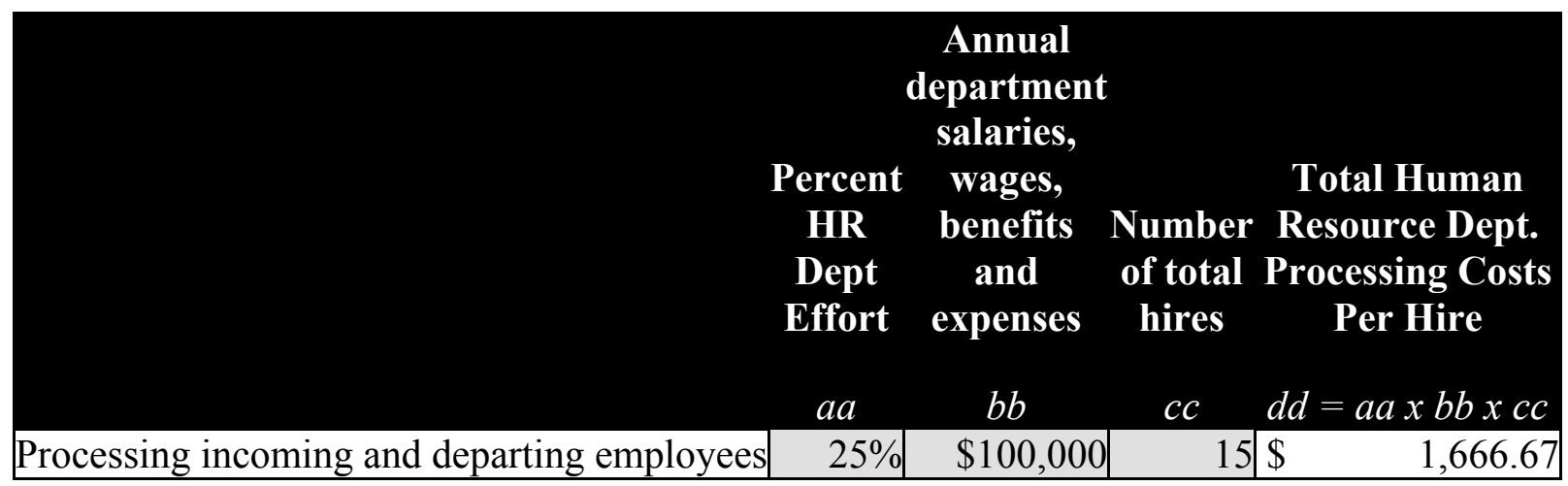

Table 17. Costs of Turnover - Human Resource Department Processing Costs.

\begin{tabular}{|c|c|c|c|}
\hline & Hours & $\begin{array}{c}\text { Hourly Salary and } \\
\text { Benefits }\end{array}$ & $\begin{array}{l}\text { Total Processing Costs Per } \\
\text { Hire - Other Departments }\end{array}$ \\
\hline $\begin{array}{l}\text { Processing a } \\
\text { replacement }\end{array}$ & $h h$ & $J j=z$ & $k k=h h x j j$ \\
\hline Hiring supervisor & 40 & 31.25 & $1,250.00$ \\
\hline Exempt staff & 20 & 17.50 & 350.00 \\
\hline Nonexempt staff & 16 & 9.38 & 150.00 \\
\hline & & & $1,750.00$ \\
\hline
\end{tabular}


Table 18. Costs of Turnover - Relocation Costs.

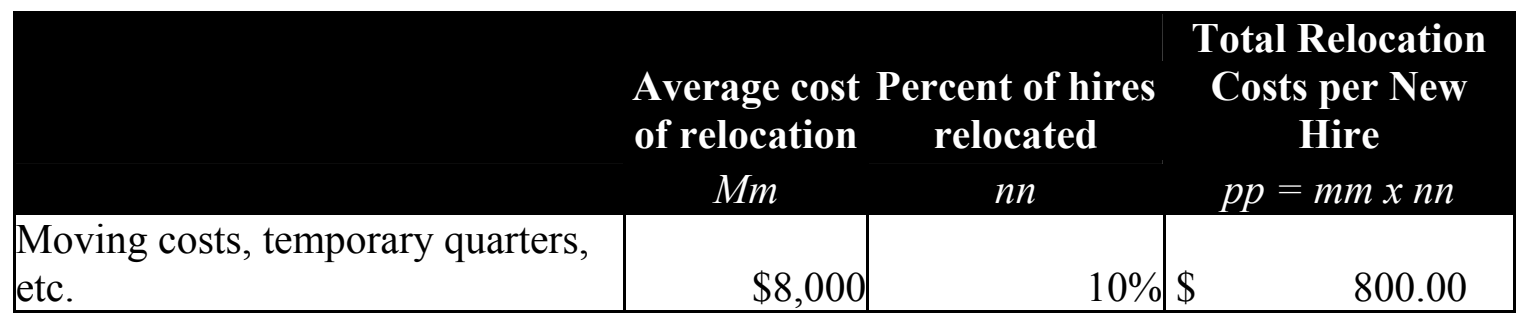

Table 19. Costs of Turnover - Inefficiency of the Incoming Employee.

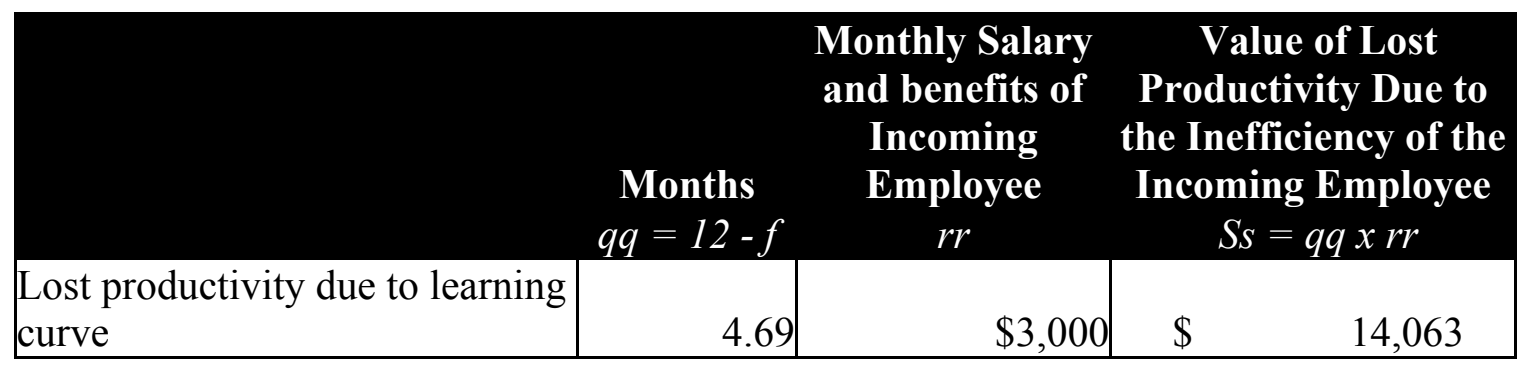

Table 20. Costs of Turnover - Inefficiency of Those Closely Associated with Incoming Employee.

\begin{tabular}{|c|c|c|c|c|}
\hline & $\begin{array}{l}\text { Percent of time } \\
\text { spent help } \\
\text { incoming } \\
\text { employee reach } \\
\text { full efficiency }\end{array}$ & $\begin{array}{l}\text { Monthly } \\
\text { salary and } \\
\text { benefits }\end{array}$ & $\begin{array}{c}\text { Total } \\
\text { Months } \\
\text { Worked } \\
\text { Until New } \\
\text { Hire at Full } \\
\text { Efficiency }\end{array}$ & $\begin{array}{c}\text { Cost of } \\
\text { Inefficiency } \\
\text { Associated with } \\
\text { Incoming } \\
\text { Employee }\end{array}$ \\
\hline $\begin{array}{l}\text { Those Closely Associated } \\
\text { with Incoming Employee }\end{array}$ & $t t$ & $u u$ & $w w=\operatorname{sum}(d)$ & $y y=t t x u u x w w$ \\
\hline Supervisor & $11 \%$ & 5,000 & 11.9 & $\$ \quad 6,545$ \\
\hline Staff & $11 \%$ & 2,800 & 11.9 & 3,665 \\
\hline Support Staff & $8 \%$ & 1,500 & 11.9 & 1,428 \\
\hline & & & & 11,638 \\
\hline
\end{tabular}


Table 21. Total Costs of Turnover.

\begin{tabular}{|l|rr|}
\hline Source of Cost & \multicolumn{2}{c|}{$\begin{array}{c}\text { Estimated } \\
\text { Cost }\end{array}$} \\
\hline Inefficiency of the Departing Employee & $\$$ & 881 \\
\hline Inefficiency of those closely associated with departing employee & $\$$ & 558 \\
\hline Inefficiency of position being filled while vacant & $\$$ & 8,959 \\
\hline Out-of-pocket processing costs & $\$$ & 1,375 \\
\hline Human resources department processing costs & $\$$ & 1,667 \\
\hline Processing costs of other departments & $\$$ & 1,750 \\
\hline Relocation costs (prorated across all hires) & $\$$ & 800 \\
\hline Incoming employee inefficiency & $\$$ & 14,063 \\
\hline Inefficiency of those closely associated with incoming employee & $\$$ & 11,638 \\
\hline Total cost of turnover & $\mathbf{4 1 , 6 9 0}$ \\
\hline Average salary and benefits of position being filled & $\$$ & 39,600 \\
\hline Ratio of cost of turnover to Average salary of position being filled & $105 \%$ \\
\hline
\end{tabular}

After estimating costs, employers can compare these costs to investment in strategies to reduce turnover. Table 22 shows data about the cost of turnover that can be used to estimate the "breakeven" point, expressed in terms of the number of employees retained by the employer. Assume the average cost per turnover was $\$ 40,000$ and the average salary and benefits of the employee was also $\$ 40,000$. The employer would recoup its investment of $\$ 100,000$ (or $\$ 100$ per month for 83 employees) in 12 months by reducing the number of employees leaving by five.

\section{Employee Retention Required Per $\$ 100,000$ Investment with a 12 month Payback.}

\begin{tabular}{|l|c|c|c|c|}
\hline \multicolumn{5}{|c|}{ Percent of Cost of Turnover to Annual Salary of Employee } \\
to Be Replaced \\
\begin{tabular}{|l|c|c|c|} 
Annual Salary of \\
$\begin{array}{l}\text { Employee to Be } \\
\text { Replaced }\end{array}$
\end{tabular} & $\mathbf{2 5 \%}$ & $\mathbf{5 0 \%}$ & $\mathbf{7 5 \%}$ & $\mathbf{1 0 0 \%}$ \\
\hline$\$ 20,000$ & & & & \\
\hline$\$ 30,000$ & 40 & 20 & 13 & 10 \\
\hline$\$ 40,000$ & 27 & 13 & 9 & 7 \\
\hline$\$ 50,000$ & 20 & 10 & 7 & 4 \\
\hline
\end{tabular}

Adapted from J. Douglas Phillips article "The Price Tag of Turnover," Personnel Journal, Dec. 1990.

Of course, there is no assurance that a particular intervention such as the introduction of a telework program or the inclusion of a day car center will reduce turnover by such an amount. The above example does place the investments in the context of the business 
objective - reducing turnover. Additional research is needed on the linkage between TDM and business benefits. Until then the question remains whether TDM agencies can actually have a substantial impact on these organizational variables through changes in either employer TDM policies or the incentives.

Any program of turnover control, including TDM strategies aimed at reducing turnover, must begin with accurate data on employee separations. Only with such information is management able to:

- Determine whether the rate of turnover is cause for concern, particularly by comparing data with national or industry averages.

- Identify major causes of employee separations, with special emphasis on avoidable separations and absences.

- Carry out measures for reducing the rate of turnover.

Exit interviews with employees or internal surveys are methods used by companies to identifying the major causes of employee separations. TDM agencies can encourage employers to include commuting-related issues in such exit interviews. For example, issues such as the price, availability or location of parking may be major concerns for a downtown employer. Strategies such as preferential treatment of carpools in assigning spaces may be a low cost way for reducing turnover. Long travel times or the quality and/or lack of transit service may be other issues employers may wish to examine, especially employers planning to relocate. These concerns may contribute to an employee's decision to leave. 


\section{Business Benefit: Reducing the Costs of Absenteeism}

Absenteeism and lateness are two of the most costly and disruptive employee problems faced daily by all business operations. Employee absenteeism occurs when an employee fails to report for work as scheduled. Organizations may classify absences as "excused" and "unexcused". Organizational policies communicate the acceptable norms from the organization to the employees. To provide a sense of the extent of the problem, the following tables provides information about the absence and lost work time rates for various occupations.

\section{Table 23. Absences From Work Of Employed Full-Time Wage And Salary Workers By Occupation (2001).}

\begin{tabular}{|c|c|c|c|c|c|c|c|}
\hline \multirow[b]{2}{*}{ Occupation } & \multirow[b]{2}{*}{$\begin{array}{c}\text { Total } \\
\text { Employed } \\
(000)\end{array}$} & \multicolumn{3}{|c|}{ Absence rate(a) } & \multicolumn{3}{|c|}{ Lost work time rate(b) } \\
\hline & & Total & $\begin{array}{l}\text { Illness } \\
\text { or } \\
\text { injury }\end{array}$ & $\begin{array}{l}\text { Other } \\
\text { reasons }\end{array}$ & Total & $\begin{array}{l}\text { Illness } \\
\text { or } \\
\text { injury }\end{array}$ & $\begin{array}{l}\text { Other } \\
\text { reasons }\end{array}$ \\
\hline $\begin{array}{l}\text { Managerial and } \\
\text { professional specialty }\end{array}$ & 32,231 & 2.9 & 1.9 & 1.0 & 1.5 & 0.9 & 0.6 \\
\hline $\begin{array}{l}\text { Executive, admin. and } \\
\text { managerial }\end{array}$ & 15,881 & 2.7 & 1.8 & 0.9 & 1.3 & 0.9 & 0.5 \\
\hline Professional specialty & 16,350 & 3.2 & 2.0 & 1.1 & 1.6 & .09 & 0.7 \\
\hline $\begin{array}{l}\text { Technical, sales, and } \\
\text { administrative support }\end{array}$ & 28,047 & 4.0 & 2.7 & 1.2 & 2.0 & 1.4 & 0.6 \\
\hline $\begin{array}{l}\text { Technicians and related } \\
\text { support }\end{array}$ & 3,755 & 4.1 & 2.9 & 1.2 & 2.0 & 1.4 & 0.6 \\
\hline Sales occupations & 10,128 & 3.1 & 2.1 & 1.0 & 1.6 & 1.1 & 0.5 \\
\hline $\begin{array}{l}\text { Administrative support, } \\
\text { including clerical }\end{array}$ & 3,755 & 4.1 & 2.9 & 1.2 & 2.0 & 1.4 & 0.6 \\
\hline Service occupations & 11,034 & 4.2 & 3.0 & 1.2 & 2.3 & 1.7 & 0.6 \\
\hline $\begin{array}{l}\text { Precision production, } \\
\text { craft, and repair }\end{array}$ & 12,006 & 3.2 & 2.5 & 0.8 & 1.8 & 1.4 & 0.3 \\
\hline $\begin{array}{l}\text { Operators, fabricators, } \\
\text { and laborers }\end{array}$ & 14,685 & 4.1 & 3.2 & 0.9 & 2.5 & 2.0 & 0.4 \\
\hline $\begin{array}{l}\text { Farming, forestry, and } \\
\text { fishing }\end{array}$ & 1,505 & 2.6 & 2.0 & 0.6 & 1.5 & 1.2 & 0.3 \\
\hline
\end{tabular}

Source: Bureau of Labor Statistics

a. Absences are defined as instances when persons who usually work 35 or more hours a week worked less than 35 hours during the reference week for one of the following reasons: Own illness, injury, or medical problems; child-care problems; other family or personal obligations; civic or military duty; and maternity or paternity leave. Excluded are situations in which work was missed due to vacation or personal days, holiday, labor dispute, and other reasons. For multiple jobholders, absence data refer only to work missed at their main jobs. The absence rate is the ratio of workers with absences to total full-time wage and salary employment.

b. Hours absent as a percent of hours usually worked. 
According to the Society of Human Resource Managers (SHRM), the three common ways of measuring absenteeism are incidence rate, inactivity rate, and severity rate. The incidence rate is a measure of the number of absences per 100 employees during any given work period. It may be adjusted to reflect a particular group of employees (e.g., employees by shift). The inactivity rate focuses on the share of time that is lost due to absenteeism. The total hours of absence is divided by the total scheduled work hours to calculate the inactivity rate. The severity rate measures the average time lost per absent employee during a specified period. The average number of hours lost by absent employers is divided by the average number of hours normally worked by the employees who are absent to estimate the severity rate.

It, therefore, becomes extremely hard for supervisors and managers to run a productive and efficient operation that runs on schedules based not only on time, but also on a specific number of employees. The cost of lower productivity, scheduling difficulties, overtime costs, lower product quality, damaged or downgraded products, shipping problems, customer service delays, and more cost millions of dollars annually.

According to the $1999 \mathrm{CCH}$ Unscheduled Absence Survey by CCH Inc, Personal illness and family issues tied as the two most common reasons for unscheduled absences, each at $21 \%$, followed by personal needs (20\%). Quickly gaining as reasons were stress and entitlement mentality, each accounting for $19 \%$ of unscheduled absences. Stress has seen a $316 \%$ increase as a reason for absenteeism since $1995 .{ }^{25}$

There are numerous challenges in measuring absenteeism or comparing the impacts of various interventions across employers. In order to effectively capture the data, it is necessary to make the time interval of recalling absences correspond to a relevant unit of time according to the work cycle and absence control system. For example, you would ask a teacher how many times s/he was absent within the last semester of a school year rather than over the past year. When unable to determine their relevant unit of time, the time interval must be long enough to allow for reliability but short enough to avoid memory loss. A review of the literature has shown that people begin to estimate instead of enumerate when the recall task is over a couple of months or involves more than a few events. Generally, 3 to 6 months is the suggested time frame, but it should be noted that there are seasonal variations in absence rates.

Perhaps most importantly, one must determine what constitutes absenteeism. Most often it is expressed as total time lost or frequency but some measure percentage of absence, 1day absences, or frequency of absences.

Fundamentally, the assumption must be made that asking questions about absenteeism may be viewed as asking threatening questions about their behavior, which is directly related to why the majority of people underreport their absences. Attendance at work is well understood by employees to be a highly valued behavior by employers. To minimize this, Johns recommends the use of longer questions that assume $\mathrm{s} /$ he has been absent, such as "People have many reasons for missing work. Most people miss an

${ }^{25}$ USA Today (Periodical) v. 128 no2659 (Apr. 2000) p. 4-5 
occasional day once and a while. How many days of work did you miss in the past month?"26

The following example lists the steps necessary for calculating the cost of absenteeism for a company with 500 employees.

Table 24. Estimating the Cost of Absenteeism.

\begin{tabular}{|c|c|c|}
\hline Number of employees & & 500 \\
\hline 1. Lost work-time rate (Hours absent as a percent of hours usually worked) & & $1.90 \%$ \\
\hline 2. Total hours usually worked ( 240 workdays $x 8$ hours per day x no. of employees) & & 960,000 \\
\hline 3. Hours lost due to absence $(\# 1 \mathrm{x} \# 2)$ & & 18,240 \\
\hline 4. Median weekly earnings (all types for example) & $\$$ & 597 \\
\hline 5. Median Hours worked (Average hours, persons who usually work full time) & & 42.8 \\
\hline 6. Weighted average hourly salary/wage $(\# 4 / \# 5)$ & $\$$ & 13.95 \\
\hline 7. Employee benefits expressed as percent of salary/wage & & $30 \%$ \\
\hline 8. Cost of employee benefits per hour per employee $(\# 6 * \# 7)$ & $\$$ & 4.18 \\
\hline 9. Total compensation lost per hour per absent employee & $\$$ & 18.13 \\
\hline 10. Total compensation lost to absent employees & $\$$ & 330,749 \\
\hline 11. Total supervisory person-hours lost to employee absenteeism per year & & 1,459 \\
\hline 12. Median weekly earnings (supervisor for example) & & $\$ 696$ \\
\hline 13. Median Hours worked (Average hours, persons who usually work full time) & & 42.8 \\
\hline 14. Weighted average hourly salary/wage (\#12/\#13) & & $\$ 16.26$ \\
\hline 15. Supervisor benefits expressed as percent of salary/wage & & $30 \%$ \\
\hline 16. Cost of supervisor benefits per hour & $\$$ & 4.88 \\
\hline 17. Total supervisor compensation per hour spent on absenteeism $(\# 14+\# 16)$ & $\$$ & 21.14 \\
\hline 18. Total supervisory salaries lost to managing problems of absenteeism $(\# 11 \mathrm{x} \# 17)$ & $\$$ & 30,848 \\
\hline 19. All other costs incidental to absenteeism, not included above & 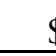 & \\
\hline 20. Total estimated cost of absenteeism (sum of \#10,\#18,\#19) & $\$$ & 361,597 \\
\hline 21. Total estimated cost of absenteeism per employee & $\$$ & 723.19 \\
\hline
\end{tabular}

The following table relates the total maximum investment allowed to reduce the cost of turnover by a targeted amount. The budget numbers are based on investments per 100 employees. For example, if the current cost per employee due to absenteeism is $\$ 600$ per employee for a company with 500 employees and they expect the TDM program to

26 Johns, Gary. How often were you absent? A review of the use of self-reported absence data. Journal of Applied Research 79(4):574-591. 1994 
reduce the cost by $20 \%$ then the company could budget up to $\$ 30,000$ to recoup the company's investment in absentee reduction within one year.

Table 25. Maximum Investment Per 100 Employees Allowed to Reduce Cost of Employee Absenteeism To Reach Goal (with a 12 month return on investment).

\begin{tabular}{|c|c|c|c|c|c|c|c|c|c|c|c|}
\hline \multirow{2}{*}{$\begin{array}{l}\text { Absentee } \\
\text { Cost Per } \\
\text { Employee }\end{array}$} & \multicolumn{11}{|c|}{ Absenteeism Cost Reduction Goal } \\
\hline & & $10 \%$ & & $15 \%$ & & $20 \%$ & $25 \%$ & $30 \%$ & $40 \%$ & & $50 \%$ \\
\hline$\$ 400$ & $\$$ & 2,000 & $\$$ & 3,000 & $\$$ & 4,000 & $\$ 5,000$ & $\$ 6,000$ & $\$ 8,000$ & $\$$ & 10,000 \\
\hline$\$ 450$ & $\$$ & 2,250 & $\$$ & 3,375 & $\$$ & 4,500 & $\$ 5,625$ & $\$ 6,750$ & $\$ 9,000$ & $\$$ & 11,250 \\
\hline$\$ 500$ & $\$$ & 2,500 & $\$$ & 3,750 & $\$$ & 5,000 & $\$ 6,250$ & $\$ 7,500$ & $\$ 10,000$ & $\$$ & 12,500 \\
\hline$\$ 550$ & $\$$ & 2,750 & $\$$ & 4,125 & $\$$ & 5,500 & $\$ 6,875$ & $\$ 8,250$ & $\$ 11,000$ & $\$$ & 13,750 \\
\hline$\$ 600$ & $\$$ & 3,000 & $\$$ & 4,500 & $\$$ & 6,000 & $\$ 7,500$ & $\$ 9,000$ & $\$ 12,000$ & $\$$ & 15,000 \\
\hline$\$ 650$ & $\$$ & 3,250 & $\$$ & 4,875 & $\$$ & 6,500 & $\$ 8,125$ & $\$ 9,750$ & $\$ 13,000$ & $\$$ & 16,250 \\
\hline$\$ 700$ & $\$$ & 3,500 & $\$$ & 5,250 & $\$$ & 7,000 & $\$ 8,750$ & $\$ 10,500$ & $\$ 14,000$ & $\$$ & 17,500 \\
\hline$\$ 750$ & $\$$ & 3,750 & $\$$ & 5,625 & $\$$ & 7,500 & $\$ 9,375$ & $\$ 11,250$ & $\$ 15,000$ & $\$$ & 18,750 \\
\hline$\$ 800$ & $\$$ & 4,000 & $\$$ & 6,000 & $\$$ & 8,000 & $\$ 10,000$ & $\$ 12,000$ & $\$ 16,000$ & $\$$ & 20,000 \\
\hline$\$ 850$ & $\$$ & 4,250 & $\$$ & 6,375 & $\$$ & 8,500 & $\$ 10,625$ & $\$ 12,750$ & $\$ 17,000$ & $\$$ & 21,250 \\
\hline$\$ 900$ & $\$$ & 4,500 & $\$$ & 6,750 & $\$$ & 9,000 & $\$ 11,250$ & $\$ 13,500$ & $\$ 18,000$ & $\$$ & 22,500 \\
\hline$\$ 950$ & $\$$ & 4,750 & $\$$ & 7,125 & $\$$ & 9,500 & $\$ 11,875$ & $\$ 14,250$ & $\$ 19,000$ & $\$$ & 23,750 \\
\hline
\end{tabular}




\section{Business Benefit: Reducing the Cost of Parking}

Shoup and others have well documented the role of parking on mode choice. ${ }^{27}$ According to Shoup, "When commuters paid for parking, they drove an average of 53 cars to work per 100 employees. When commuters parked free, they drove an average of 72 cars per 100 employees. These studies show that, per 100 commuters, employer-paid parking replaced commuters' payments for parking 53 cars (the number driven to work when commuters paid for parking), but also stimulated a 36 percent increase in the number of cars driven to work."

Parking is the most prevalent commute benefit offered by employers. The provision of parking is seemingly so prevalent that surveys such as the employer benefit survey by the BLS do not track it. To gather information on the extent of employer-provided commute benefits of all types (parking, transit and carpool/vanpool), a national telephone survey of 603 employers was conducted in 1995. The survey found that parking benefits were provided by $80 \%$ of employers whereas vanpool/carpool benefits are provided by only $3.2 \%$ and less than $1 \%$ offer transit benefits. ${ }^{28}$

\section{Table 26. Employer-Provided Commute Benefits.}

\begin{tabular}{|c|c|c|c|c|c|c|}
\hline \multirow[b]{2}{*}{ Benefits Provided } & \multirow[b]{2}{*}{ Total } & \multicolumn{5}{|c|}{ Number of Employees } \\
\hline & & $1-4$ & $5-25$ & 26-99 & 100-499 & $500+$ \\
\hline Any Commute Benefits & $80.1 \%$ & $80.0 \%$ & $77.2 \%$ & $92.0 \%$ & $93.2 \%$ & $93.0 \%$ \\
\hline Parking benefits & $79.8 \%$ & $80.0 \%$ & $76.2 \%$ & $92.0 \%$ & $92.6 \%$ & $92.0 \%$ \\
\hline Transit benefits & $0.5 \%$ & 0.0 & $1.0 \%$ & $2.3 \%$ & $3.4 \%$ & $15.0 \%$ \\
\hline $\begin{array}{l}\text { Administers carpool } \\
\text { and/or vanpool program }\end{array}$ & $3.2 \%$ & $4.0 \%$ & $1.0 \%$ & $2.8 \%$ & $13.6 \%$ & $36.0 \%$ \\
\hline
\end{tabular}

This survey also sought to obtain an assessment of employer practices with respect to the provision of employee transportation benefits, including parking. As the report points out, the reasons for providing parking are not decision factors. The provision of parking by employers reflects a "continuation of long standing arrangements that have not been reexamined or reflect a pass through from employers to employees of a resource that does not have a market." Only the fourth most cited reason recognizes the value to the business interests of the company.

\footnotetext{
${ }^{27}$ Donald C. Shoup, "Evaluating the Effects of Cashing Out Employer-Paid Parking: Eight Case Studies," Transport Policy, Vol. 4, No. 4, October 1997, pp. 201-216.

${ }^{28}$ Commuter Choice Initiative. KPMG Peat Marwick LLP. August 4, 1995.
} 
Table 27. Reasons for Providing a Given Commute Benefit.

Four Most Frequent Responses

Percent by Type of Benefit

PARKING BENEFITS

\begin{tabular}{|l|l|}
\hline 1. Have always provided parking & $37.4 \%$ \\
\hline 2. Receive parking as part of lease & $19.9 \%$ \\
\hline 3. Parking built along with employer's building & $9.9 \%$ \\
\hline 4. Recruitment and retention of employees & $7.9 \%$ \\
\hline TRANSIT BENEFITS &
\end{tabular}

TRANSIT BENEFITS

1. Recruitment/Retention of Employees

2. Have always provided transit benefits

3. Transit benefits are tax exempt to employees

4. Promote ridesharing/alt. transportation programs

VANPOOL/CARPOOL BENEFITS

1. No alternative transportation available

2. Environmental concerns

3. Convenience

4. Recruitment/Retention

$1.7 \%$

$6.9 \%$

$6.5 \%$

$4.5 \%$

$7.7 \%$

$39.3 \%$

$38.1 \%$

$2.8 \%$

Employers were asked to estimate the time spent administering each of these programs. Employers estimated the mean value of 7 hours per month to administer transit benefit program and 1 hour per month for the carpool/vanpool program. Perhaps the most revealing about attitudes regarding parking, is that most employers reported that administering the parking program required no time. Clearly, the costs of parking are not well-understood by the business community responsible for commute-related programs. The following section will outline the costs and a method for calculating the costs.

The cost of parking has two major components: capital (including construction) and operating. The capital cost for parking depends on numerous factors including land, design, development, and construction costs. Operating costs may include attendant, regular maintenance on the facility, security, etc. 
Table 28. Construction Cost per Parking Space.

\begin{tabular}{|c|c|c|c|}
\hline & \multicolumn{3}{|c|}{ Square Feet per Parking Space } \\
Cost Sq. Ft. & $\mathbf{2 5 0}$ & $\mathbf{3 0 0}$ & $\mathbf{3 5 0}$ \\
\hline \multicolumn{4}{|c|}{ SURFACE LOT } \\
\hline$\$ 5.00$ & $\$ 1,250$ & $\$ 1,500$ & $\$ 1,750$ \\
\hline$\$ 10.00$ & $\$ 2,500$ & $\$ 3,000$ & $\$ 3,500$ \\
\hline \multicolumn{4}{|c|}{ ABOVE GRADE STRUCTURES } \\
\hline$\$ 20.00$ & $\$ 5,000$ & $\$ 6,000$ & $\$ 7,000$ \\
\hline$\$ 25.00$ & $\$ 6,250$ & $\$ 7,500$ & $\$ 8,750$ \\
\hline$\$ 35.00$ & $\$ 8,750$ & $\$ 10,500$ & $\$ 12,250$ \\
\hline
\end{tabular}

The following tables estimate the cost of constructing a new surface lot or above grade structure, with and without the need to acquire the land. Each scenario includes two financing periods -10 and 20 years. Regardless of the scenario, it becomes abundantly clear that the cost to construct and maintain a parking facility would require significant revenue per month to breakeven. Given that employers provide most of the parking to employees for "free", the employer is incurring this expense in SG\&A.

Table 29. Cost of Parking - Surface Lot Scenarios.

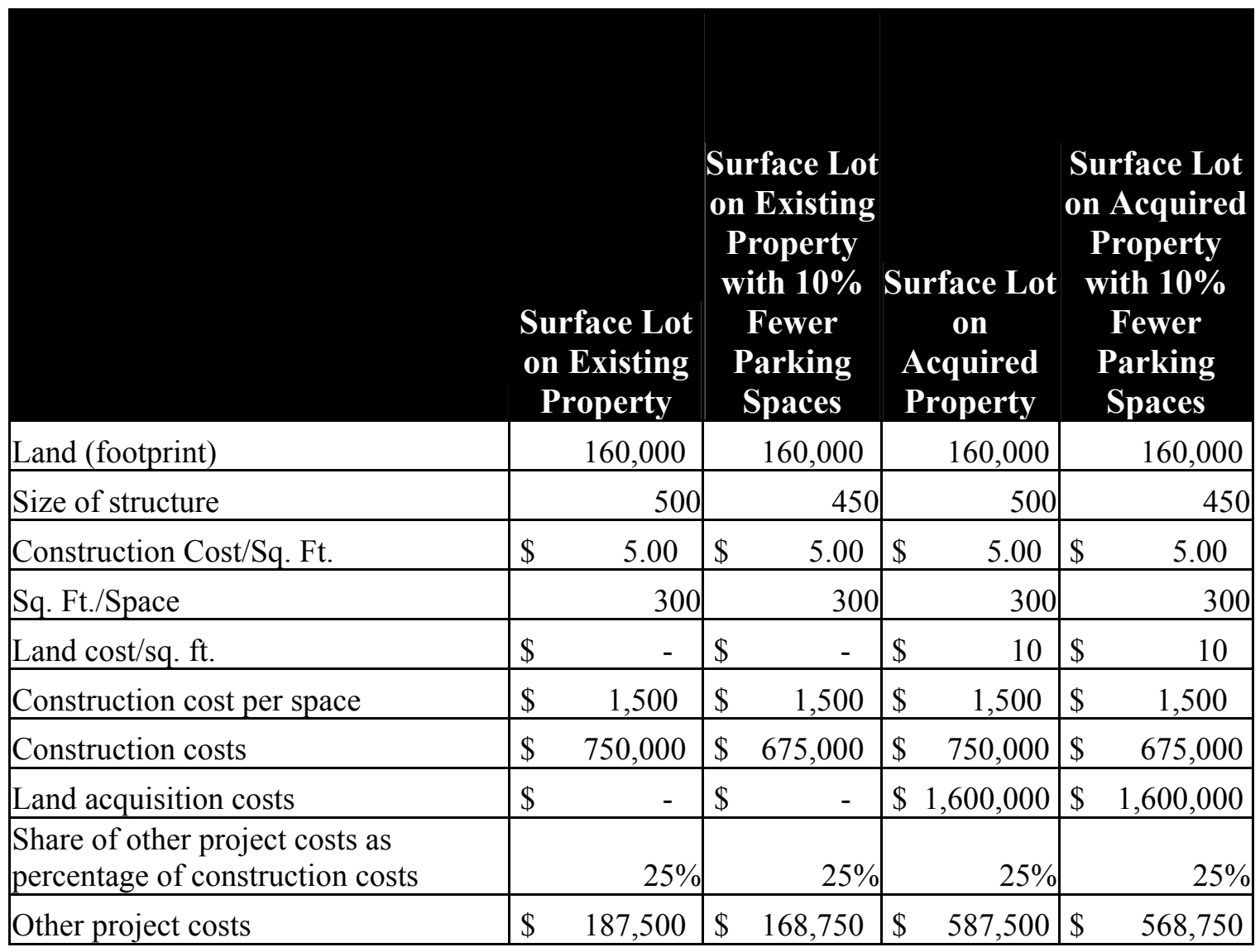




\begin{tabular}{|c|c|c|c|c|}
\hline & $\begin{array}{c}\text { Surface Lot } \\
\text { on Existing } \\
\text { Property }\end{array}$ & \begin{tabular}{|c|} 
Surface Lot \\
on Existing \\
Property \\
with $10 \%$ \\
Fewer \\
Parking \\
Spaces
\end{tabular} & $\begin{array}{l}\text { Surface Lot } \\
\text { on } \\
\text { Acquired } \\
\text { Property } \\
\end{array}$ & $\begin{array}{c}\text { Surface Lot } \\
\text { on Acquired } \\
\text { Property } \\
\text { with } 10 \% \\
\text { Fewer } \\
\text { Parking } \\
\text { Spaces }\end{array}$ \\
\hline Total project cost & 937,500 & $\$ \quad 843,750$ & $\$ 2,937,500$ & $\$ \quad 2,843,750$ \\
\hline Interest rate & $8 \%$ & $8 \%$ & $8 \%$ & $8 \%$ \\
\hline Financing term (years) & 10 & 10 & 10 & 10 \\
\hline Annual debt service & $(\$ 139,715)$ & $(\$ 125,744)$ & $(\$ 437,774)$ & $(\$ 423,803)$ \\
\hline Total financed cost & $(\$ 1,397,152)$ & $(\$ 1,257,437)$ & $(\$ 4,377,742)$ & $(\$ 4,238,026)$ \\
\hline Total interest paid & $\$ \quad(459,652)$ & $\$(413,686)$ & $\$(1,440,241)$ & $\$(1,394,276)$ \\
\hline Project Cost per space & 1,875 & 1,875 & 5,875 & 6,319 \\
\hline Annual capital cost per space & $(\$ 279)$ & $(\$ 279)$ & $(\$ 876)$ & $(\$ 942)$ \\
\hline Annual operating cost per space & $(\$ 400)$ & $(\$ 400)$ & $(\$ 400)$ & $(\$ 400)$ \\
\hline Total annual cost per space & $(\$ 679)$ & $(\$ 679)$ & $(\$ 1,276)$ & $(\$ 1,342)$ \\
\hline Required revenue per space per month & $(\$ 57)$ & $(\$ 57)$ & $(\$ 106)$ & $(\$ 112)$ \\
\hline Financing term (years) & 20 & 20 & 20 & 20 \\
\hline Annual debt service & $(\$ 95,486)$ & $(\$ 85,938)$ & $(\$ 299,191)$ & $(\$ 289,642)$ \\
\hline Total financed cost & $(\$ 1,909,729)$ & $(\$ 1,718,757)$ & $(\$ 5,983,818)$ & $(\$ 5,792,845)$ \\
\hline Total interest paid & $(972,229)$ & $\$(875,006)$ & $\$(3,046,318)$ & $\$(2,949,095)$ \\
\hline Annual capital cost per space & $(\$ 191)$ & $(\$ 191)$ & $(\$ 598)$ & $(\$ 644)$ \\
\hline Annual operating cost per space & $(\$ 400)$ & $(\$ 400)$ & $(\$ 400)$ & $(\$ 400)$ \\
\hline Total annual cost per space & $(\$ 591)$ & $(\$ 591)$ & $(\$ 998)$ & $(\$ 1,044)$ \\
\hline Required revenue per space per month & $(\$ 49)$ & $(\$ 49)$ & $(\$ 83)$ & $(\$ 87)$ \\
\hline
\end{tabular}


Table 30. Cost of Parking - Above Grade Structure Scenarios.

\begin{tabular}{|c|c|c|c|c|}
\hline & $\begin{array}{c}\text { Above } \\
\text { Grade } \\
\text { Structure } \\
\text { on Existing } \\
\text { Property }\end{array}$ & $\begin{array}{c}\text { Above } \\
\text { Grade } \\
\text { Structure } \\
\text { on Existing } \\
\text { Property } \\
\text { with } 10 \% \\
\text { Fewer } \\
\text { Parking } \\
\text { Spaces }\end{array}$ & \begin{tabular}{c|} 
\\
\\
\\
Above \\
Grade \\
Structure \\
on Existing \\
Property
\end{tabular} & $\begin{array}{c}\text { Above } \\
\text { Grade } \\
\text { Structure } \\
\text { on Existing } \\
\text { Property } \\
\text { with } 10 \% \\
\text { Fewer } \\
\text { Parking } \\
\text { Spaces }\end{array}$ \\
\hline Land (footprint) & 160,000 & 160,000 & 160,000 & 160,000 \\
\hline Size of structure & 500 & 450 & 500 & 450 \\
\hline Construction Cost/Sq. Ft. & 35.00 & 35.00 & 35.00 & 35.00 \\
\hline Sq. Ft./Space & 300 & 300 & 300 & 300 \\
\hline Land cost/sq. ft. & $\$$ & $\$$ & 20 & 20 \\
\hline Construction cost per space & 10,500 & 10,500 & 10,500 & 10,500 \\
\hline Construction costs & \begin{tabular}{|l|} 
\\
$5,250,000$ \\
\end{tabular} & \begin{tabular}{|l|l}
$\$$ \\
$4,725,000$ \\
\end{tabular} & $5,250,000$ & $4,725,000$ \\
\hline Land acquisition costs & $\$$ & $\$$ & $\$ \quad 3,200,000$ & $3,200,000$ \\
\hline $\begin{array}{l}\text { Share of other project costs as } \\
\text { percentage of construction costs }\end{array}$ & $25 \%$ & $25 \%$ & $25 \%$ & $25 \%$ \\
\hline Other project costs & $\$ 1,312,500$ & $\$ \quad 1,181,250$ & $\$ \quad 2,112,500$ & $1,981,250$ \\
\hline Total project cost & $\$ \quad 6,562,500$ & $\$ \quad 5,906,250$ & $\$ 10,562,500$ & $9,906,250$ \\
\hline Interest rate & $8 \%$ & $8 \%$ & $8 \%$ & $8 \%$ \\
\hline Financing term (years) & 10 & 10 & 10 & 10 \\
\hline Annual debt service & $(\$ 978,006)$ & $(\$ 880,205)$ & $(\$ 1,574,124)$ & $(\$ 1,476,323)$ \\
\hline Total financed cost & $(\$ 9,780,061)$ & $(\$ 8,802,055)$ & $(\$ 15,741,240)$ & $(\$ 14,763,234)$ \\
\hline Total interest paid & $\$(3,217,560)$ & $\$(2,895,804)$ & $\$ 5,178,740)$ & $\$ 4,856,984)$ \\
\hline Project Cost per space & 13,125 & 13,125 & 21,125 & 22,014 \\
\hline Annual capital cost per space & $(\$ 1,956)$ & $(\$ 1,956)$ & $(\$ 3,148)$ & $(\$ 3,281)$ \\
\hline Annual operating cost per space & $(\$ 400)$ & $(\$ 400)$ & $(\$ 400)$ & $(\$ 400)$ \\
\hline Total annual cost per space & $(\$ 2,356)$ & $(\$ 2,356)$ & $(\$ 3,548)$ & $(\$ 3,681)$ \\
\hline Required revenue per space per month & $(\$ 196)$ & $(\$ 196)$ & $(\$ 296)$ & $(\$ 307)$ \\
\hline Financing term (years) & 20 & 20 & \begin{tabular}{|r|}
20 \\
\end{tabular} & 20 \\
\hline Annual debt service & $(\$ 668,405)$ & $(\$ 601,565)$ & $(\$ 1,075,814)$ & $(\$ 1,008,973)$ \\
\hline Total financed cost & $(\$ 13,368,103)$ & $(\$ 12,031,293)$ & $(\$ 21,516,280)$ & $(\$ 20,179,469)$ \\
\hline Total interest paid & $\$(6,805,603)$ & $\$(6,125,042)$ & & \\
\hline
\end{tabular}




\begin{tabular}{|c|c|c|c|c|}
\hline & $\begin{array}{c}\text { Above } \\
\text { Grade } \\
\text { Structure } \\
\text { on Existing } \\
\text { Property }\end{array}$ & $\begin{array}{c}\text { Above } \\
\text { Grade } \\
\text { Structure } \\
\text { on Existing } \\
\text { Property } \\
\text { with 10\% } \\
\text { Fewer } \\
\text { Parking } \\
\text { Spaces }\end{array}$ & $\begin{array}{c}\text { Above } \\
\text { Grade } \\
\text { Structure } \\
\text { on Existing } \\
\text { Property }\end{array}$ & $\begin{array}{c}\text { Above } \\
\text { Grade } \\
\text { Structure } \\
\text { on Existing } \\
\text { Property } \\
\text { with 10\% } \\
\text { Fewer } \\
\text { Parking } \\
\text { Spaces }\end{array}$ \\
\hline & & & $\$(10,953,779)$ & $\$(10,273,219)$ \\
\hline Annual capital cost per space & $(\$ 1,337)$ & $(\$ 1,337)$ & $(\$ 2,152)$ & $(\$ 2,242)$ \\
\hline Annual operating cost per space & $(\$ 400)$ & $(\$ 400)$ & $(\$ 400)$ & $(\$ 400)$ \\
\hline Total annual cost per space & $(\$ 1,737)$ & $(\$ 1,737)$ & $(\$ 2,552)$ & $(\$ 2,642)$ \\
\hline Required revenue per space per month & $(\$ 145)$ & $(\$ 145)$ & $(\$ 213)$ & $(\$ 220)$ \\
\hline
\end{tabular}

Changes in parking demand will depend on the TDM program strategies offered. The COMMUTER Model and CUTR_AVR model provide the means for estimating the change in vehicle trips and, therefore, potential reductions in parking demand. As one might expect, the amount of vehicle trip reduction can vary significantly depending on the incentives and disincentives offered by employers. A review of the literature finds reductions in vehicle trips in the $20 \%$ to $40 \%$ range are possible though not typical. 


\section{Business Benefit: Employer-Provided Commuter Benefits}

The "qualified transportation fringe benefit" (QTFB) is a provision of the Internal Revenue Code (IRC), Section 132 (f), that permits employers to subsidize their employees' cost of commuting to work by transit and vanpools up to $\$ 100$ per month. Up to $\$ 190$ per month can be provided by employers to employees for parking at or near an employer's worksite, or at a facility from which employee commutes via transit, vanpool, or carpool. It also allows employees to use pre-tax dollars to pay for their qualified transportation fringe benefits such as transit passes, vanpool fares, and qualified parking.

Employers are not required to provide the QTFB. How and under what circumstances an employer provides these benefits to its employees is entirely within the employer's discretion. The employer may provide only one kind of benefit or all types of qualified transportation fringe benefits, at its sole discretion.

A closer look at commuting-related benefits finds that three percent of all private employers provide subsidized commuting in 2000, down from four percent in 1999. In 2000 , this benefit was more common among companies with more than 100 employees with 5 percent versus 2 percent for companies with 1 to 99 employees. $^{29} 30$

\section{Table 31. Subsidized Commuting Trends for Medium and Large Private Employers.}

\begin{tabular}{|l|c|c|c|c|}
\hline & All Employees & $\begin{array}{c}\text { Professional, } \\
\text { technical and } \\
\text { related }\end{array}$ & $\begin{array}{c}\text { Clerical and sales } \\
\text { employees }\end{array}$ & $\begin{array}{c}\text { Blue-collar and } \\
\text { service employees }\end{array}$ \\
\hline 1995 & 5 & 8 & 5 & 3 \\
\hline 1997 & 6 & 10 & 7 & 3 \\
\hline 1999 & 4 & 9 & 4 & 3 \\
\hline 2000 & 3 & 6 & 3 & 2 \\
\hline
\end{tabular}

According to a survey by Bright Horizons Family Solutions and William M. Mercer, a human resources consulting concern, employers cited flexible work arrangements as the most beneficial work/life benefit. ${ }^{31}$ National statistics show that increasing numbers and proportions of full-time workers in the United States are able to opt for flexible work hours, allowing workers to vary the actual times they arrive and leave the work place. Among full-time wage and salary workers, according to BLS, nearly 28.8 percent had

\footnotetext{
${ }^{29}$ Employee Benefits in Private Industry, 2000. Bureau of Labor Statistics. July 16, 2002. http://stats.bls.gov/ncs/ebs/sp/ebnr0007.pdf

${ }^{30}$ Employee Benefits in Private Industry, 1999. Bureau of Labor Statistics. December 19, 2001. http://stats.bls.gov/ncs/ebs/sp/ebnr0006.pdf

${ }^{31}$ Business Publishers, Inc. The National Report on Work \& Family. January 26, 1999. p11
} 
flexible work schedules. About one-third of these workers (11.1 percent of the total) worked flexible hours as part of a formal employer-sponsored flexitime program. ${ }^{32}$

One frequently mentioned benefit cited is the ability to reduce taxes by providing commuter benefits to employees and/or allowing employees to similar to a flexible spending account. Section 132(f) of the Internal Revenue Code permits employers to provide employees tax-free qualified transportation fringe benefits. As of January 1, 2003, employers can provide employees with up to $\$ 100$ per month for transit passes/vouchers or commuter highway vehicle. A commuter highway vehicle must hold at least 6 people excluding the driver, be used $80 \%$ mileage for commuting and carry at least 4 people including the driver.

Initially, employers may view the commuter choice tax benefits like other cafeteria benefit plans. However, there are several important distinctions between cafeteria benefits such as flexible spending accounts (FSAs) authorized under Section 125 and qualified transportation fringe benefit (QTFB) programs authorized under Section 132 that will have a bearing on participation and administration. Under medical flexible spending accounts, for example, eligible claims can be reimbursed up to the plan year election less any prior reimbursements. If the person elects to set aside $\$ 100$ per month (\$1,200 annually), for example, for eligible medical expenses and incurs $\$ 800$ in eligible expenses in the second month, he or she can receive the full $\$ 800$ though he may have only paid in $\$ 200$ into the plan year.

Commuter benefit reimbursements programs also are different from the other traditional benefit programs that employers may offer their employees. These QTFB programs are not required to operate under a specific plan year concept with an open enrollment period; QTFBs can operate on a monthly basis (or other cycle). Therefore, all elections, deposits and reimbursements are calculated and recorded on a monthly basis, and each month is seen as a separate period of time from all other months employer's employees participate. As a result, QTFB claims can only be reimbursed up to the balance in the account when the claim is processed and can not to exceed the IRS monthly maximum. Therefore, in the first month, the employee, in effect, pays twice for the same transit pass. For example, the employee's pay is deducted $\$ 65$ for a transit pass in May. However, since this is a reimbursement program, the employee must also purchase the transit pass from the employer or transit operator and submit a receipt or proof of purchase/use to the third-party administrator (TPA) for reimbursement. The employee will then receive a $\$ 65$ check from the TPA (i.e., from the $\$ 65$ taken out of their paycheck in May). The lag time between the cash outlay by the employee and receipt of the reimbursement will depend on employer policies and the processing speed of the TPA.

Eligibility for these programs is quite broad. Any type of transit service, publicly or privately owned or operated, including bus, rail, subway, ferry, subscription bus, shuttle bus, and commuter highway vehicles under contract which provides general or special service on a regular and continuing basis to the public and/or employees are eligible uses

\footnotetext{
${ }^{32}$ Bureau of Labor Statistics. Workers On Flexible And Shift Schedules In 2001. April 18, 2002. http://stats.bls.gov/news.release/flex.nr0.htm
} 
under Section 132. In addition, transportation in a commuter highway vehicle (vanpool) which is provided "by-and for" (on behalf of) the employer is eligible for the Transportation Commute Benefit. These types of vanpool arrangements are: employerowned; employer-leased; employee-owned; employee-leased, and public transit operated/

Under Section 132(f)(2), an employee may receive a qualified parking benefit in addition to the transit or commuter highway vehicle benefit. The designated employee "prime member" (often the driver or the person assigned the parking space) who travels in a commuter highway vehicle (e.g., vanpool) that uses commercial parking is eligible for the parking benefit (up to $\$ 190 /$ month), and at the same time he is entitled to the commuter highway vehicle benefit (up to $\$ 100 /$ month). All other employees commuting in a highway vehicle who are not the "prime member" are only eligible for the vanpool benefit, not the parking benefit. Another employee might choose to combine up to $\$ 100 /$ month for using transit and up to $\$ 190$ of the qualified parking benefit to subsidize the employee's cost of parking at a train station and riding transit.

While transit riders and vanpool riders are eligible recipients, carpoolers, bicyclists and/or walkers are not covered under the Transportation Commute Benefit. However, employers may offer incentive programs that would be taxable subsidies for employees who chose to walk, bicycle, or carpool to work.

As noted above, employers can give their employees up to $\$ 100 /$ month to commute via transit or vanpool and up to $\$ 190$ per month for parking. Such expenses are tax deductible to the employer and cost the employer less than providing the employee an equivalent raise in gross income.

Employers can also allow employees to use pre-tax income to pay for qualified transportation fringes. Even the employer does not provide a transit subsidy or copayment; employers will save on payroll taxes. Finally, employers have the utmost flexibility in offering any combination of the transit and vanpool benefits and the pre-tax options up to statutory limits.

In addition to providing flexibility on the investment in the program, employers can offer the benefit to any employee or group of employees within the work force. The amount can vary among employees, it can be provided on a regular basis or once a year instead of a bonus, or it can be provided as recruitment or an incentive payment to address a problem such as recurring absenteeism. It can also be used only for a limited group of employees or available to all employees, at the employer's discretion. It must, however, be provided for commuting expenses--not for personal travel.

Employer involvement must occur if the benefits are to accrue to the business and the employees. While an employee may buy transit passes without going through the employer, there is no way that the employee can obtain the tax savings without employer involvement. QTFB are employer-provided benefits that allow employers to treat benefits provided to employees in a tax-preferred way. The employee cannot deduct the amount when they file their personal income tax forms. However, the employer can treat the 
amount they provide to their employees in the form of qualified transportation fringe benefits as tax free and excludible from gross income of the employee thereby giving employees a financial saving.

Employers certainly incur costs for implementing the program, primarily in the administration and record keeping areas. The employer's record keeping requirements of the QTFB require, in the case of cash reimbursements, a bona-fide reimbursement arrangement to meet the adequate record keeping requirement. Even then cash reimbursement option only exists for employers where a voucher program is not readily available. There are exceptions to this prohibition against the use of cash reimbursement. Employers are allowed to used cash reimbursement if faced with extenuating circumstances such as incurring handling charges of more than 1 percent and/or unreasonable minimum dollar or volume purchase requirements (e.g., employer would be required by the transit agency to purchase 100 passes per month but they only have 20 employees who ride transit each month).

In the case of the voucher system used for transit or vanpools, employers need only maintain a record of the purchase of the vouchers. In all other cases, the employer must maintain adequate records, which reasonably demonstrates expenditures under the benefit. As an example, in the case of an employer who participates in a transit pass program by selling passes of a local transit provider at a discount, the employer should keep records of the pass sales to employees in addition to the arrangement with the transit provider(s).

If the employer utilizes a cash reimbursement system, employees may have to provide the employer with receipts or some record of their expenses. If the employee receives vouchers from his or her employer to pay for transit expenses, for example, he or she may not have any record keeping requirements but the employee may have to certify to his or her use of transit and monthly expenses to the employer. There is no employee record keeping requirements for purposes of any tax filing such as the annual personal income tax form. The amount of the fringe benefit an employee receives from their employer will not be included in an employee's W-2 form, for example.

The IRS may make annual adjustments to the limits each December for the following calendar year. Increases triggered by cost of living increases only occur in $\$ 5$ increments. However, the employer makes the decision if and when to increase the benefit or even whether to provide the maximum regardless of whether the employer or employee is paying for the benefit.

The following example is provided to show the savings that could accrue to one individual and her employer. Nita Ryder lives in Florida (no state income tax), is single, earns $\$ 30,920$ per year, claims one exemption, takes the standard deduction on her taxes, and is a dedicated transit rider (Table 32). After the tax break signed into law by President Bush in 2003, she has decided to estimate the increase in her spendable income if she decided to use pre-tax income to pay for her $\$ 100$ per month transit pass. 
Table 32. Qualified Transportation Fringe Benefit Example - Assumptions.

\begin{tabular}{|c|c|c|}
\hline \multicolumn{3}{|c|}{ Assumption Comment } \\
\hline adjusted Gross Income & $\$ 30,920.00$ & $\begin{array}{l}\text { For example (Florida } 2001 \text { averages): } \$ 66,960 \\
\text { for managerial occupations, } \$ 30,920 \text { all } \\
\text { occupations; } \$ 25,110 \text { office and administrative } \\
\text { support occupations }\end{array}$ \\
\hline b $\mid$ Yearly Commute Benefit & $\$ \quad 1,200.00$ & $\begin{array}{l}\text { Maximum tax-free benefit for transit and } \\
\text { vanpools is } \$ 100 \text { per month per worker; may } \\
\text { be combined with parking }\end{array}$ \\
\hline c Yearly Parking Cost & $\$$ & $\begin{array}{l}\text { Maximum tax-free benefit for parking is } \$ 190 \\
\text { per month per worker; may be combined with } \\
\text { transit or vanpool benefit }\end{array}$ \\
\hline $\mathrm{d}$ Exemptions & & Number exemptions claimed on 1040 \\
\hline e Withholding Allowance & $\$ 3,100.00$ & $\begin{array}{l}\text { Source: IRS Notice } 1036 \text { May } 2003 \text { for } \\
\text { monthly payroll period }\end{array}$ \\
\hline f $\mathrm{FICA}$ & $7.65 \%$ & Up to $\$ 87,000$ \\
\hline g Standard Deduction & $4,500.00$ & per exemption \\
\hline $\mathrm{h} \mid$ Marital Status (Married (M) or Single (S)) & & Marital status \\
\hline
\end{tabular}

Using Table 34 to estimate her tax liability, the first column in Table 33 shows that without the pre-tax commute benefit program her net income after paying taxes would be $\$ 26,972$. After paying for her monthly transit passes $(\$ 1,200$ for the year), she was left with $\$ 25,772$ in spendable income. However, under Nita's employer pre-tax commute benefit option, she could choose to deduct $\$ 100$ per month from her gross pay before taxes to buy the transit pass. As a result, her spendable income increased by $\$ 263$ per year.

It should be noted that while her FICA contribution also decreased by $\$ 92$ per year so did her employer's matching contribution. As a result of this new program, Nita saved \$263 per year and her employer saved $\$ 92$ per year (less the discount that would have been received by the business when it deducts the expense as a business expense). 
Table 33. Comparison of Pre-Tax Qualified Transportation Fringe Benefit Plan.

\begin{tabular}{|c|c|c|c|c|}
\hline & & $\begin{array}{c}\text { Without Pre- } \\
\text { Tax Qualified } \\
\text { Transportation } \\
\text { Fringe Benefit } \\
\text { Plan }\end{array}$ & $\begin{array}{c}\text { With Pre-Tax } \\
\text { Qualified } \\
\text { Transportation } \\
\text { Fringe Benefit } \\
\text { Plan } \\
\end{array}$ & \\
\hline $\mathrm{j}$ & Adjusted Gross Income & $\$ 30,920.00$ & $\$ 30,920.00$ & $j=a$ \\
\hline $\mathrm{k}$ & Pretax Commuter Benefits & $\$$ & $\$ \quad(1,200.00)$ & $\begin{array}{l}\mathrm{k}=0 \text { for no pretax } \\
\text { arrangement; } \\
\mathrm{k}=-\mathrm{b} \text { for pretax commute } \\
\text { benefit }\end{array}$ \\
\hline 1 & Pretax Parking & $\$$ & $\$$ & $\begin{array}{l}1=0 \text { for no pretax } \\
\text { arrangement; } 1=-d \text { for pretax } \\
\text { parking }\end{array}$ \\
\hline $\mathrm{m}$ & Taxable Adjusted Gross Income & $\$ \quad 30,920.00$ & $\$ \quad 29,720.00$ & $m=j+k+1$ \\
\hline $\mathrm{n}$ & Standard deduction & $\$ \quad(4,500.00)$ & $(4,500.00)$ & $\mathrm{n}=\mathrm{g}$ \\
\hline $\mathrm{p}$ & $\begin{array}{l}\text { Total exemptions multiplied by } \\
\text { withholding allowance ( } \$ 3,100 \text { for } \\
2003 \text { ) }\end{array}$ & $\$ \quad(3,100.00)$ & $\$ \quad(3,100.00)$ & $p=d \times e$ \\
\hline $\mathrm{q}$ & Taxable Income & $23,320.00$ & $22,120.00$ & $\mathrm{q}=\mathrm{m}+\mathrm{n}+\mathrm{p}$ \\
\hline $\mathrm{r}$ & Withholding tax & $\$ \quad(1,583.00)$ & $\$ \quad(1,412.00)$ & $\begin{array}{l}\mathrm{r}=\text { Withholding tax } \\
\text { determined by using the } \\
\text { taxable gross (q) for the } \\
\text { appropriate row of either the } \\
\text { Single or Married tables } \\
\text { below. }\end{array}$ \\
\hline $\mathrm{s}$ & FICA ( $7.65 \%$ of Taxable Gross) & $\$ \quad(2,365.38)$ & $\$ \quad(2,273.58)$ & $\mathrm{s}=\mathrm{m} \times \mathrm{f}$ \\
\hline $\mathrm{t}$ & Net income & $26,971.62$ & $26,034.42$ & $\mathrm{t}=\mathrm{m}+\mathrm{r}+\mathrm{s}$ \\
\hline $\mathrm{u}$ & Commuter Benefits & $\$ \quad(1,200.00)$ & $\$$ & $\begin{array}{l}\mathrm{u}=0 \text { for no pretax } \\
\text { arrangement; } \\
\mathrm{u}=-\mathrm{b} \text { for pretax commute } \\
\text { benefit }\end{array}$ \\
\hline $\mathrm{V}$ & Parking & $\$$ & $\$$ & $\begin{array}{l}\mathrm{v}=0 \text { for no pretax } \\
\text { arrangement; } \\
\mathrm{v}=-\mathrm{d} \text { for pretax parking }\end{array}$ \\
\hline $\mathrm{W}$ & Spendable Income & $\$ 25,771.62$ & $26,034.42$ & $\mathrm{w}=\mathrm{t}+\mathrm{u}+\mathrm{v}$ \\
\hline$y$ & Annual Savings & & $(262.80)$ & $\mathrm{y}=\mathrm{w}$ (without) $-\mathrm{w}$ (with) \\
\hline $\mathrm{z}$ & Monthly Savings & & $(21.90)$ & $z=y / 12$ \\
\hline
\end{tabular}


Table 34. 2003 Tax Tables - Single Person (including head of household).

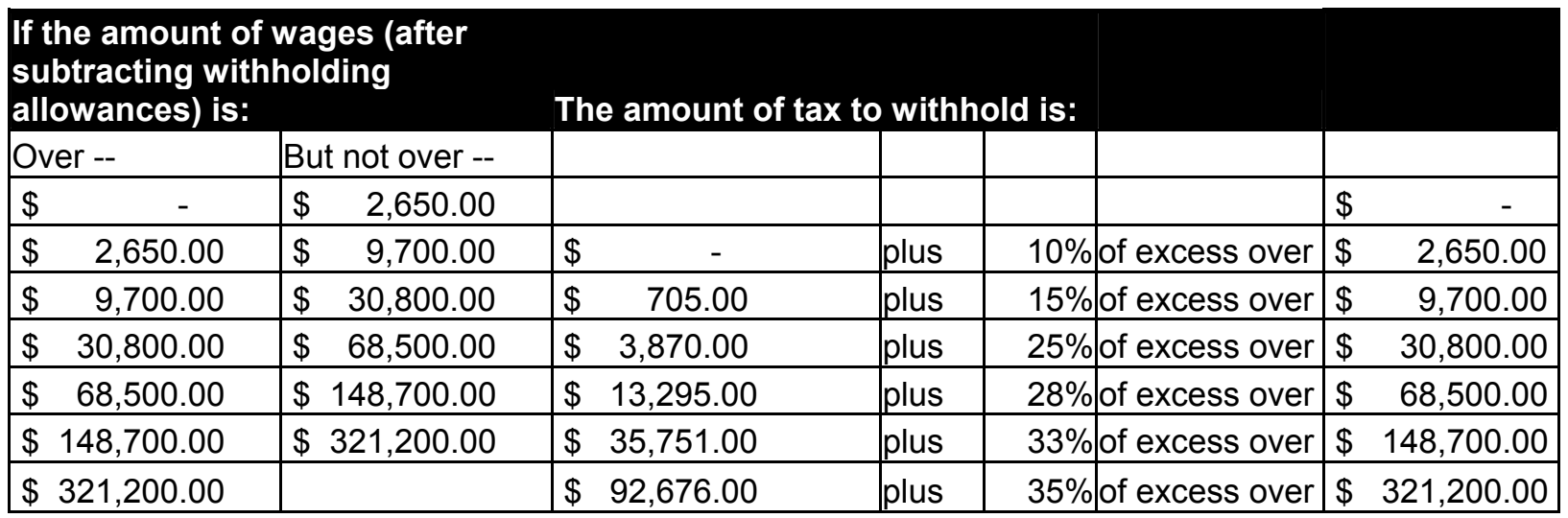

Table 35. 2003 Tax Tables - Married Person.

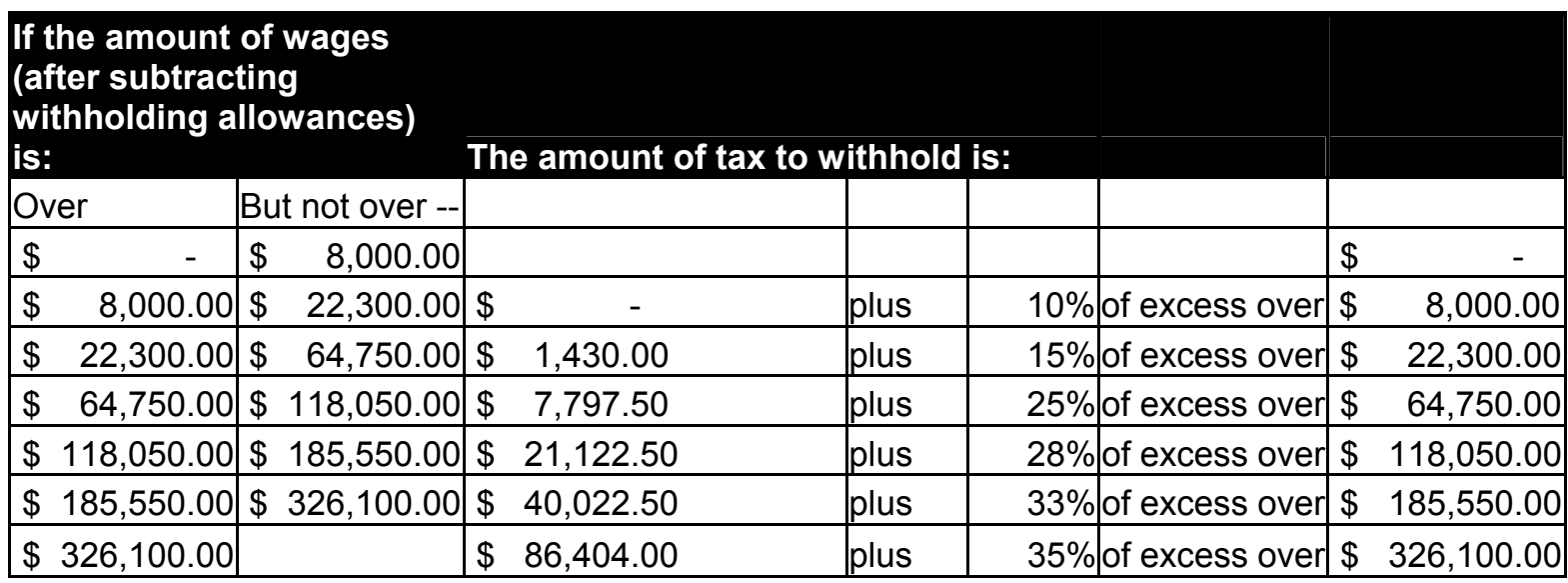

The annual increase in spendable income depends on the marital status, number of exemptions, the pre-tax benefit set aside and the adjusted gross income. The following tables provide estimates of the increases in spendable income for several scenarios. For example, a single person with 1 exemption making $\$ 40,000$ per year would increase spendable income by $\$ 392$ per year by using $\$ 100$ per month in pre-tax dollars to purchase a transit pass or parking permit. A married person making the same amount would increase spendable income by $\$ 272$ with the same $\$ 100$ amount set aside. 
Table 36. Increase in Spendable Income to Employee with Pre-Tax Benefit - Single Person.

\begin{tabular}{|c|c|c|c|c|c|c|c|c|c|c|c|c|c|}
\hline \multicolumn{2}{|c|}{$\begin{array}{l}\text { Adjusted } \\
\text { Gross } \\
\text { Income }\end{array}$} & \multicolumn{2}{|c|}{$\begin{array}{c}\text { Single } 1 \\
\text { exempt. } \\
\text { @\$50 per } \\
\text { month }\end{array}$} & \multicolumn{2}{|c|}{$\begin{array}{c}\text { Single } 1 \\
\text { exempt. } \\
\text { @\$100 } \\
\text { per } \\
\text { month }\end{array}$} & \multicolumn{2}{|c|}{$\begin{array}{c}\text { Single } 1 \\
\text { exempt. } \\
\text { @\$190 } \\
\text { per } \\
\text { month }\end{array}$} & \multicolumn{2}{|c|}{$\begin{array}{c}\text { Single } 1 \\
\text { exempt. } \\
@ \$ 290 \\
\text { per month }\end{array}$} & $\begin{array}{c}\text { Single } 2 \\
\text { exempt. } \\
\text { @\$50 per } \\
\text { month }\end{array}$ & $\begin{array}{c}\text { Single } 2 \\
\text { exempt. } \\
@ \$ 100 \text { per } \\
\text { month }\end{array}$ & $\begin{array}{c}\text { Single } 2 \\
\text { exempt. } \\
\text { @ } \$ 190 \text { per } \\
\text { month }\end{array}$ & $\begin{array}{c}\text { Single } 2 \\
\text { exempt. } \\
\text { @ } \$ 290 \text { per } \\
\text { month }\end{array}$ \\
\hline$\$$ & 10,000 & $\$$ & 46 & $\$$ & 92 & $\$$ & 174 & No & axes & No taxes & No taxes & No taxes & No taxes \\
\hline$\$$ & 15,000 & $\$$ & 106 & $\$$ & 212 & $\$$ & 402 & $\$$ & 614 & $\$ \quad 106$ & $\$ \quad 212$ & $\$ \quad 339$ & $\$ \quad 431$ \\
\hline$\$$ & 20,000 & $\$$ & 136 & $\$$ & 272 & $\$$ & 516 & $\$$ & 749 & 106 & 212 & 402 & 614 \\
\hline$\$$ & 25,000 & $\$$ & 136 & $\$$ & 272 & $\$$ & 516 & $\$$ & 788 & 136 & 272 & 516 & 788 \\
\hline$\$$ & 30,000 & $\$$ & 136 & $\$$ & 272 & $\$$ & 516 & $\$$ & 788 & 136 & 272 & 516 & 788 \\
\hline$\$$ & 35,000 & $\$$ & 136 & $\$$ & 272 & $\$$ & 516 & $\$$ & 788 & 136 & 272 & 516 & 78 \\
\hline$\$$ & 40,000 & $\$$ & 196 & $\$$ & 392 & $\$$ & 676 & $\$$ & 948 & 136 & 272 & 516 & 788 \\
\hline$\$$ & 45,000 & $\$$ & 196 & $\$$ & 392 & $\$$ & 744 & $\$$ & 1,136 & 196 & 392 & 744 & 1,136 \\
\hline$\$$ & 50,000 & $\$$ & 196 & $\$$ & 392 & $\$$ & 744 & $\$$ & 1,136 & 196 & 392 & 744 & 1,13 \\
\hline$\$$ & 55,000 & $\$$ & 196 & $\$$ & 392 & $\$$ & 744 & $\$$ & 1,136 & 196 & 392 & 744 & 1,136 \\
\hline$\$$ & 60,000 & $\$$ & 196 & $\$$ & 392 & $\$$ & 744 & $\$$ & 1,136 & 196 & 392 & 744 & 1,136 \\
\hline$\$$ & 65,000 & $\$$ & 196 & $\$$ & 392 & $\$$ & 744 & $\$$ & 1,136 & 196 & 392 & 744 & 1,136 \\
\hline$\$$ & 70,000 & $\$$ & 196 & $\$$ & 392 & $\$$ & 744 & $\$$ & 1,136 & 196 & 392 & 744 & 1,136 \\
\hline$\$$ & 75,000 & $\$$ & 196 & $\$$ & 392 & $\$$ & 744 & $\$$ & 1,136 & 196 & 392 & 744 & 1,136 \\
\hline$\$$ & 80,000 & $\$$ & 214 & $\$$ & 428 & $\$$ & 813 & $\$$ & 1,241 & 214 & 416 & 768 & 1,160 \\
\hline$\$$ & 85,000 & $\$$ & 214 & $\$$ & 428 & $\$$ & 813 & $\$$ & 1,241 & 214 & 428 & 813 & 1,241 \\
\hline
\end{tabular}


Table 37. Increase in Spendable Income to Employee with Pre-Tax Benefit Married Person.

\begin{tabular}{|c|c|c|c|c|c|c|c|c|c|c|c|c|c|}
\hline \multicolumn{2}{|c|}{$\begin{array}{l}\text { Adjusted } \\
\text { Gross } \\
\text { Income }\end{array}$} & \multicolumn{2}{|c|}{$\begin{array}{c}\text { Married } 2 \\
\text { exempt } \\
@ \$ 50 \text { per } \\
\text { month }\end{array}$} & \multicolumn{2}{|c|}{$\begin{array}{c}\text { Married } 2 \\
\text { exempt } \\
\text { @\$100 } \\
\text { per } \\
\text { month }\end{array}$} & \multicolumn{2}{|c|}{$\begin{array}{c}\text { Married } 2 \\
\text { exempt } \\
\text { @\$190 } \\
\text { per } \\
\text { month }\end{array}$} & \multicolumn{2}{|c|}{$\begin{array}{c}\text { Married } 2 \\
\text { exempt } \\
@ \$ 290 \\
\text { per month }\end{array}$} & $\begin{array}{c}\text { Married } 4 \\
\text { exempt } \\
@ \$ 50 \text { per } \\
\text { month }\end{array}$ & $\begin{array}{c}\text { Married } 4 \\
\text { exempt } \\
\text { @ } \$ 100 \text { per } \\
\text { month }\end{array}$ & $\begin{array}{c}\text { Married } 4 \\
\text { exempt } \\
@ \$ 190 \text { per } \\
\text { month }\end{array}$ & $\begin{array}{c}\text { Married } 4 \\
\text { exempt } \\
@ \$ 290 \text { per } \\
\text { month }\end{array}$ \\
\hline$\$$ & 10,000 & & & & xes & & ixes & No & axes & No taxes & No taxes & No taxes & No taxes \\
\hline$\$$ & 15,000 & No & & No & xes & & ixes & No & axes & No taxes & No taxes & No taxes & No taxes \\
\hline$\$$ & 20,000 & $\$$ & 106 & $\$$ & 212 & $\$$ & 389 & $\$$ & 481 & No taxes & No taxes & No taxes & No taxes \\
\hline$\$$ & 25,000 & $\$$ & 111 & $\$$ & 217 & $\$$ & 407 & $\$$ & 619 & 106 & 187 & 269 & 361 \\
\hline$\$$ & 30,000 & $\$$ & 136 & $\$$ & 272 & $\$$ & 516 & $\$$ & 788 & 106 & 212 & 402 & 614 \\
\hline$\$$ & 35,000 & $\$$ & 136 & $\$$ & 272 & $\$$ & 516 & $\$$ & 788 & 136 & 272 & 516 & 788 \\
\hline$\$$ & 40,000 & $\$$ & 136 & $\$$ & 272 & $\$$ & 516 & $\$$ & 788 & 136 & 272 & 516 & 788 \\
\hline$\$$ & 45,000 & $\$$ & 136 & $\$$ & 272 & $\$$ & 516 & $\$$ & 788 & 136 & 272 & 516 & $\$$ \\
\hline$\$$ & 50,000 & $\$$ & 196 & $\$$ & 392 & $\$$ & 744 & $\$$ & 1,136 & 136 & 272 & 516 & 78 \\
\hline$\$$ & 55,000 & $\$$ & 196 & $\$$ & 392 & $\$$ & 744 & $\$$ & 1,136 & 196 & 392 & 744 & 1,068 \\
\hline$\$$ & 60,000 & $\$$ & 196 & $\$$ & 392 & $\$$ & 744 & $\$$ & 1,136 & 196 & 392 & 744 & 1,13 \\
\hline$\$$ & 65,000 & $\$$ & 196 & $\$$ & 392 & $\$$ & 744 & $\$$ & 1,136 & 196 & 392 & 744 & 1,136 \\
\hline$\$$ & 70,000 & $\$$ & 196 & $\$$ & 392 & $\$$ & 744 & $\$$ & 1,136 & 196 & 392 & 744 & 1,136 \\
\hline$\$$ & 75,000 & $\$$ & 196 & $\$$ & 392 & $\$$ & 744 & $\$$ & 1,136 & 196 & 392 & 744 & 1,136 \\
\hline$\$$ & 80,000 & $\$$ & 196 & $\$$ & 392 & $\$$ & 744 & $\$$ & 1,136 & 196 & 392 & 744 & 1,136 \\
\hline$\$$ & 85,000 & $\$$ & 214 & $\$$ & 428 & $\$$ & 783 & $\$$ & 1,175 & 196 & 392 & 744 & 1,136 \\
\hline
\end{tabular}

The use of pre-tax payments for commute benefits provides employers with a cost effective method for increasing the spendable income of employees without increasing the gross salary (and any benefits based on the gross salary such as retirement, life insurance, etc.). In addition, the employer will save on payroll taxes. For employees earning up to $\$ 87,000$, the employers pay 7.65 percent of the taxable adjusted gross income as payroll taxes (FICA and Medicare). Over $\$ 87,000$, the employees no longer pay FICA. This amount matches the employee-paid amount. Lowering the taxable adjusted gross income, therefore, decreases the payroll tax paid by the employer. At the same time, the amount of savings accruing the employers (before claiming corporate tax deductions) is modest. 
Table 38. Total Estimated Annual Payroll Tax Savings to Employer.

\begin{tabular}{|c|c|c|c|c|}
\hline \multirow[t]{2}{*}{$\begin{array}{l}\text { Employee Pre- } \\
\text { tax Monthly } \\
\text { Amount }\end{array}$} & \multirow[t]{2}{*}{$\begin{array}{l}\text { Employer } \\
\text { Annual FICA } \\
\text { Savings Per } \\
\text { Employee }\end{array}$} & \multicolumn{3}{|c|}{$\begin{array}{l}\text { Total Estimated Annual Payroll Tax Savings to } \\
\text { Employer } \\
\qquad \text { (\# of employees participating) }\end{array}$} \\
\hline & & 100 & 500 & 1000 \\
\hline$\$ 50$ & $\$ 45.90$ & $\$ 4,590$ & $\$ 22,950$ & $\$ 45,900$ \\
\hline$\$ 100$ & $\$ 91.80$ & $\$ 9,180$ & $\$ 45,900$ & $\$ 91,800$ \\
\hline$\$ 190$ & $\$ 174.42$ & $\$ 17,442$ & $\$ 87,210$ & $\$ 174,420$ \\
\hline$\$ 290$ & $\$ 266.22$ & $\$ 26,622$ & $\$ 133,110$ & $\$ 266,220$ \\
\hline
\end{tabular}




\section{Chapter 4 - Conclusions and Recommendations}

The review of the efforts to quantify business benefits by employers and agencies points to several clear conclusions and recommendations.

1. Increase public sector research and technical assistance efforts to evaluate employer TDM programs for the impacts on business, not only transportation and emission impacts. Businesses do attribute benefits to various TDM programs but no systematic, consistent method of measuring these benefits exists. In fact, some employers are reluctant to share results because of the perceived competitive advantage it provides. This project has compiled various techniques for measuring some of the major benefits of TDM.

Establishing a standard methodology for measuring the change across employers would allow for comparison of the relative effectiveness of given strategies whether or not the information is shared with the outside world. Employers and agencies should be encouraged and supported to use the human-cost approach, tracking costs before the intervention is offered and comparing those costs measured after the intervention. This is perhaps the easiest approach. Ideally, comparing costs and between users and nonusers of the intervention would provide a means of assessing the relative effectiveness.

2. Expand the tracking of employer-provided commute benefits to include parking. The Bureau of Labor Statistics tracks subsidized commuting benefits and flexible work place information. State departments of transportation and groups such as the Association for Commuter Transportation should encourage BLS to add parking (including the employer-provided subsidized parking) benefits to the list. This addition would begin to allow employers to see parking as a benefit rather than a right. The tracking of the subsidy amount would increase its visibility as a Selling, General and Administrative cost to the business, and, thus, controllable.

3. Integrate, update, and aggressively distribute the tools to estimate the impacts and costs/benefits of TDM to businesses. Whether the employers implicitly or explicitly quantify the benefits of TDM to their business, the need remains for tools to help quantify the business as well as the community benefits of TDM. The current tools each bring particular strengths and weaknesses. An effort to more closely integrate the tools to assist business would be beneficial. The mere existence of the tools does not mean they are widely used, or even known to exist among the target populations. One tactic would be to provide TDM agencies with a copy of the Business Benefit Calculator javascript program to place on their own websites so their businesses in their areas could find it. It should also allow for the locals to customize the default values to their communities. Another tactic would be to establish self-paced online training programs (e.g., streaming video) to help teach employers and TDM agencies how to use these particular tools 


\section{Appendix A - COMMUTER Model Screen Shots}

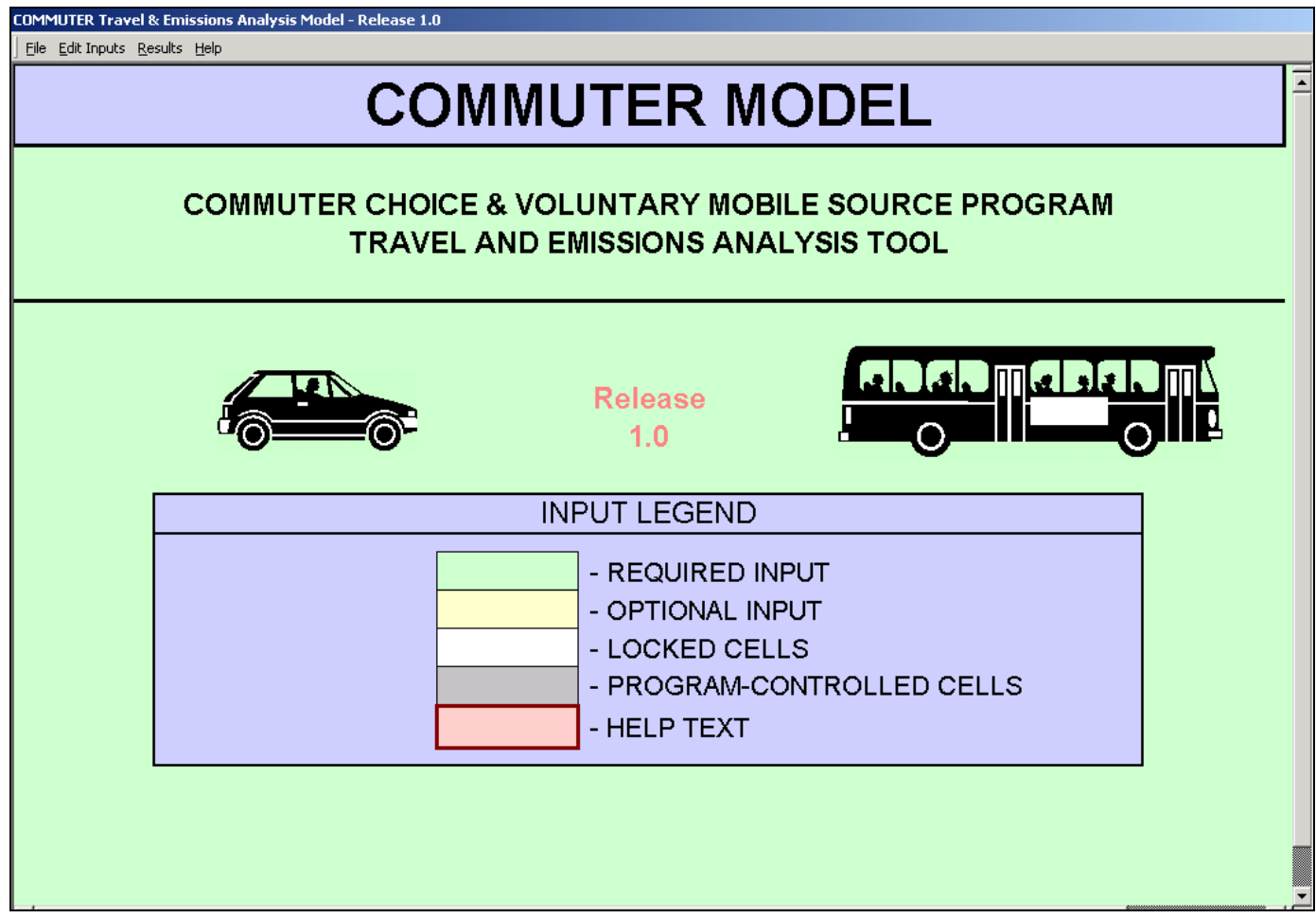

Figure 11. Commuter Model Opening Screen.

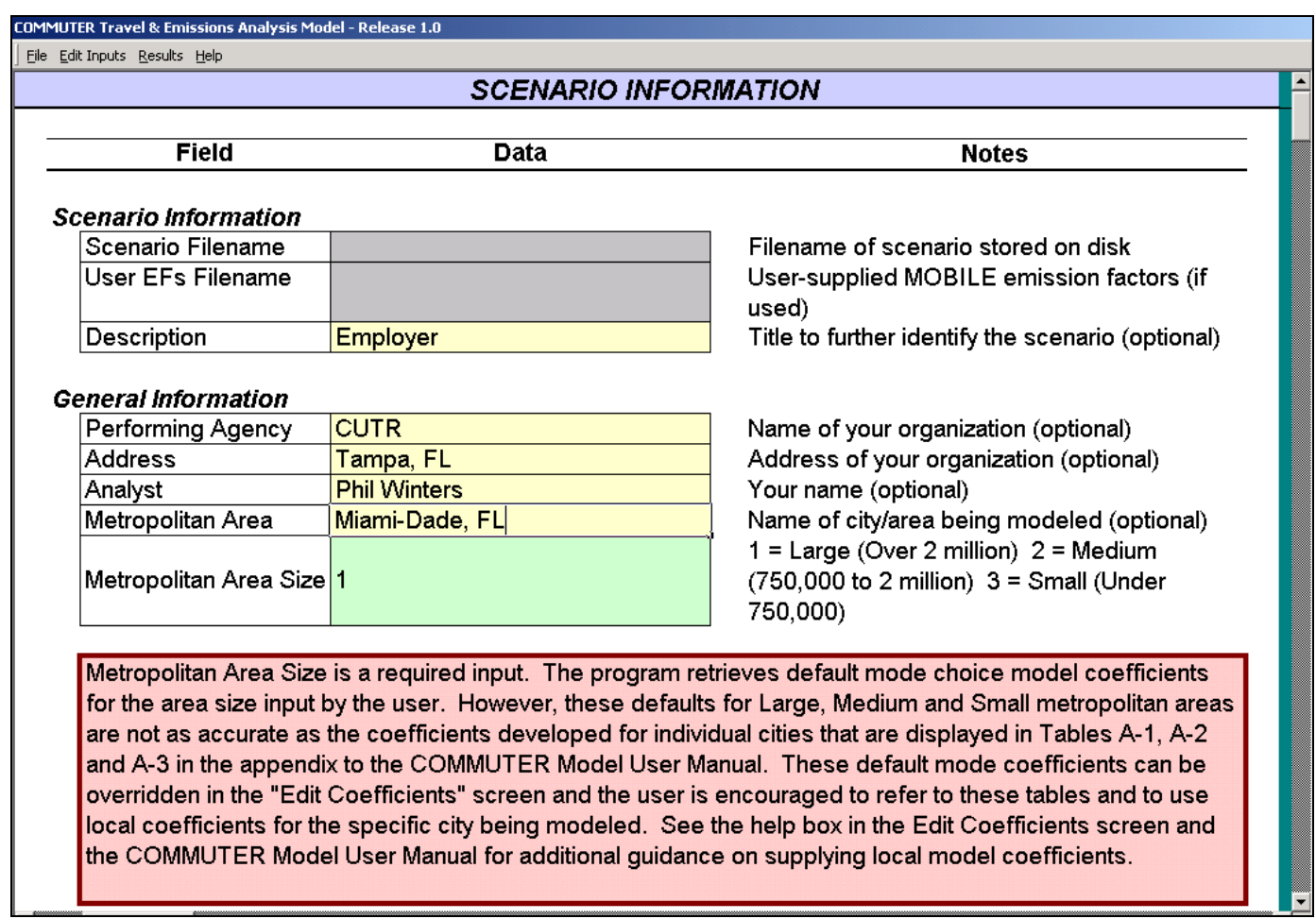

Figure 12. Commuter Model - Scenario Information Screen. 


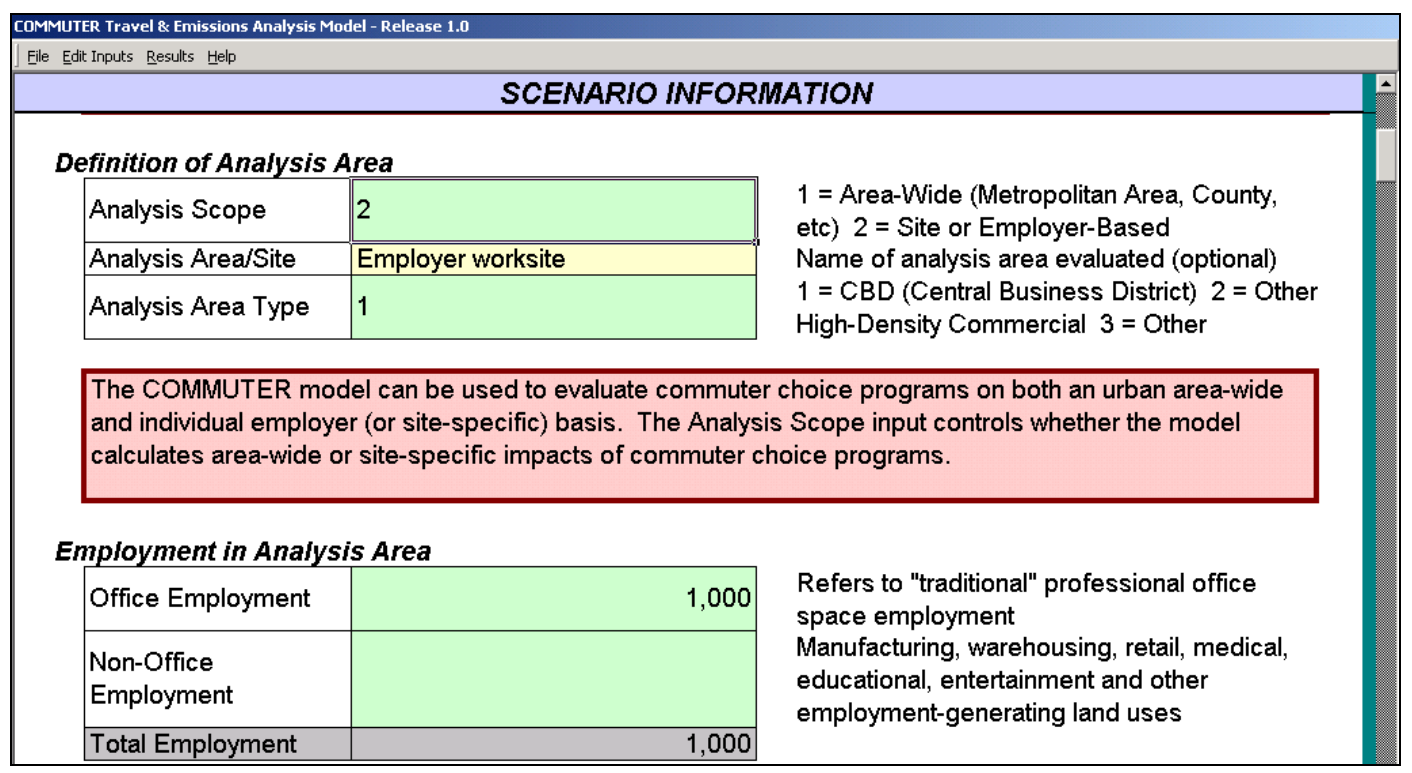

Figure 13. Commuter Model - Scenario Information Screen (cont.).

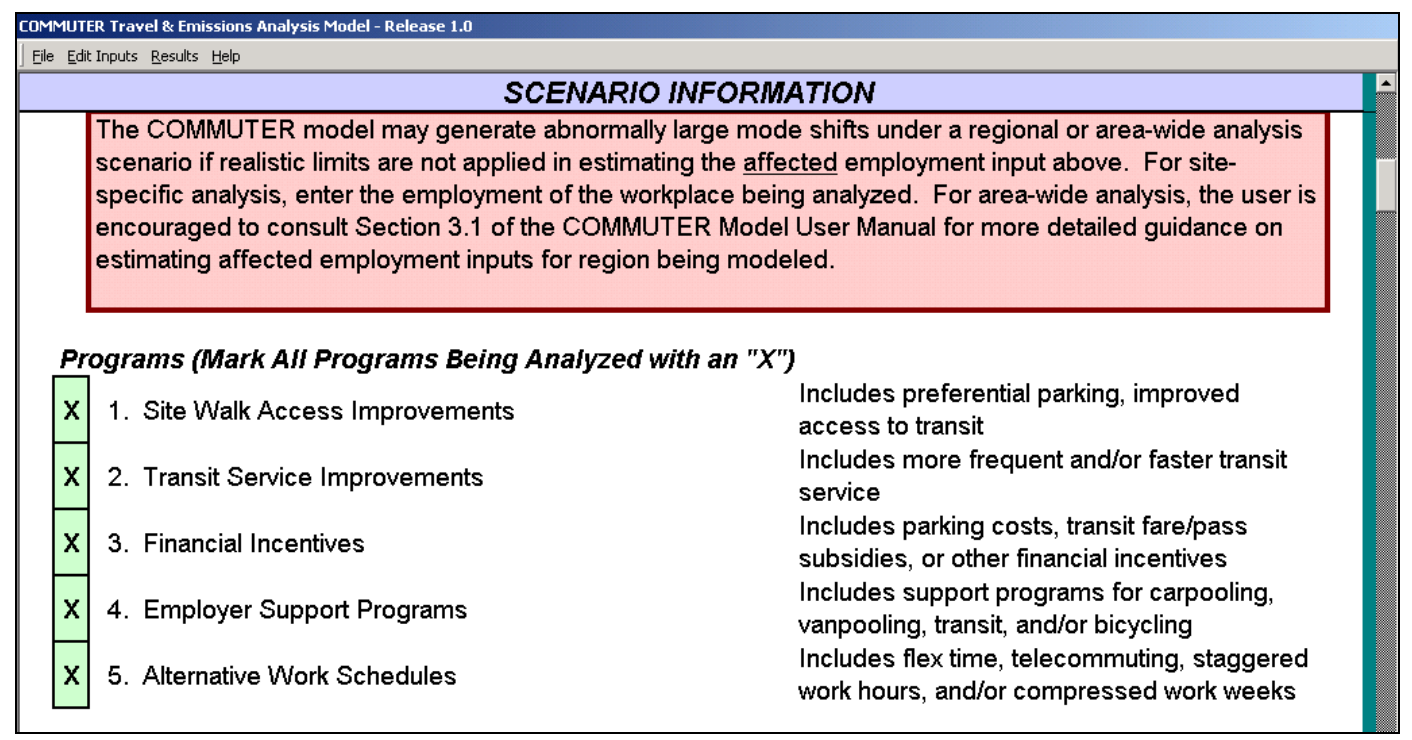

Figure 14. Commuter Model - Scenario Information Screen (cont.). 


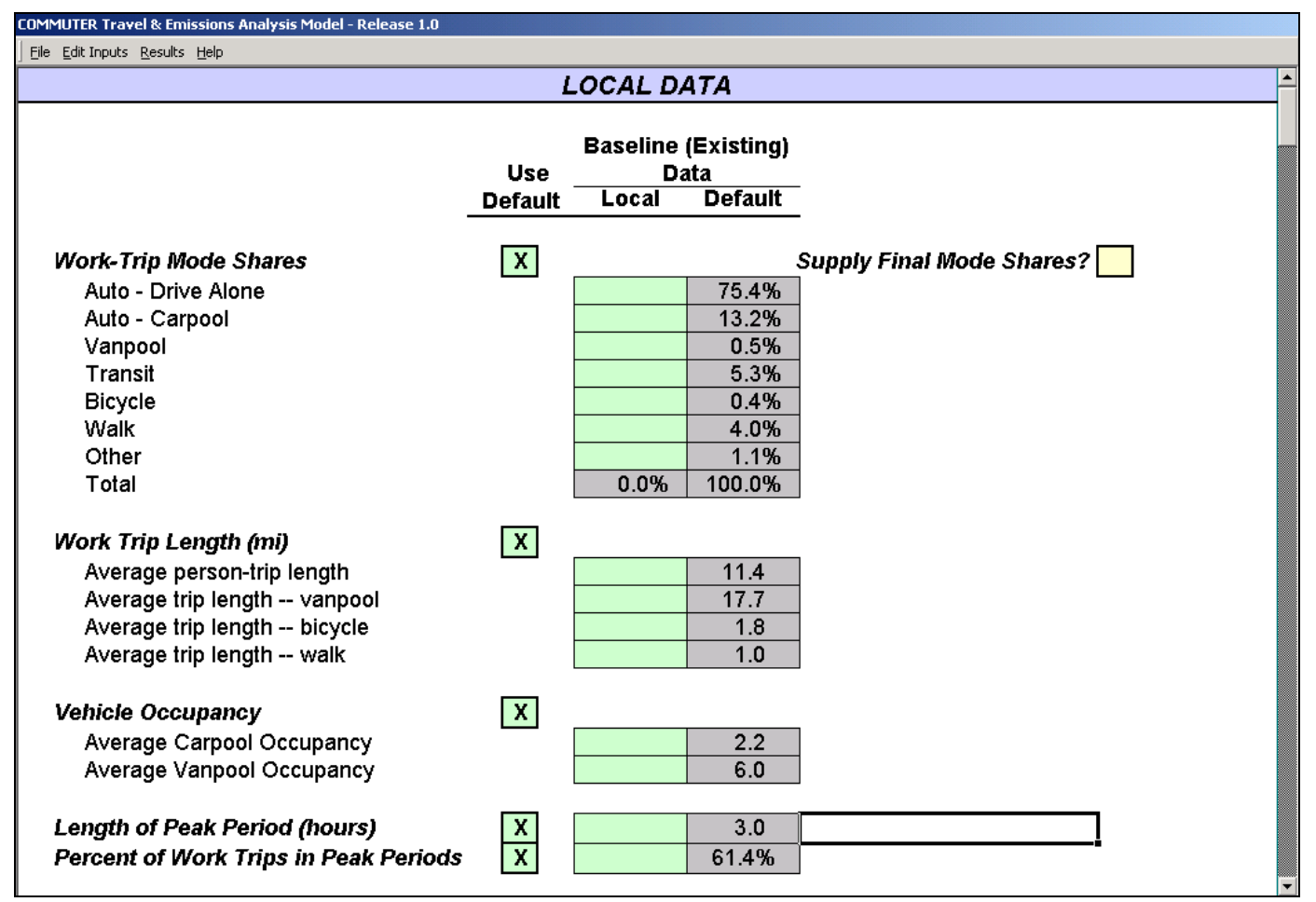

Figure 15. Commuter Model - Local Data Screen.

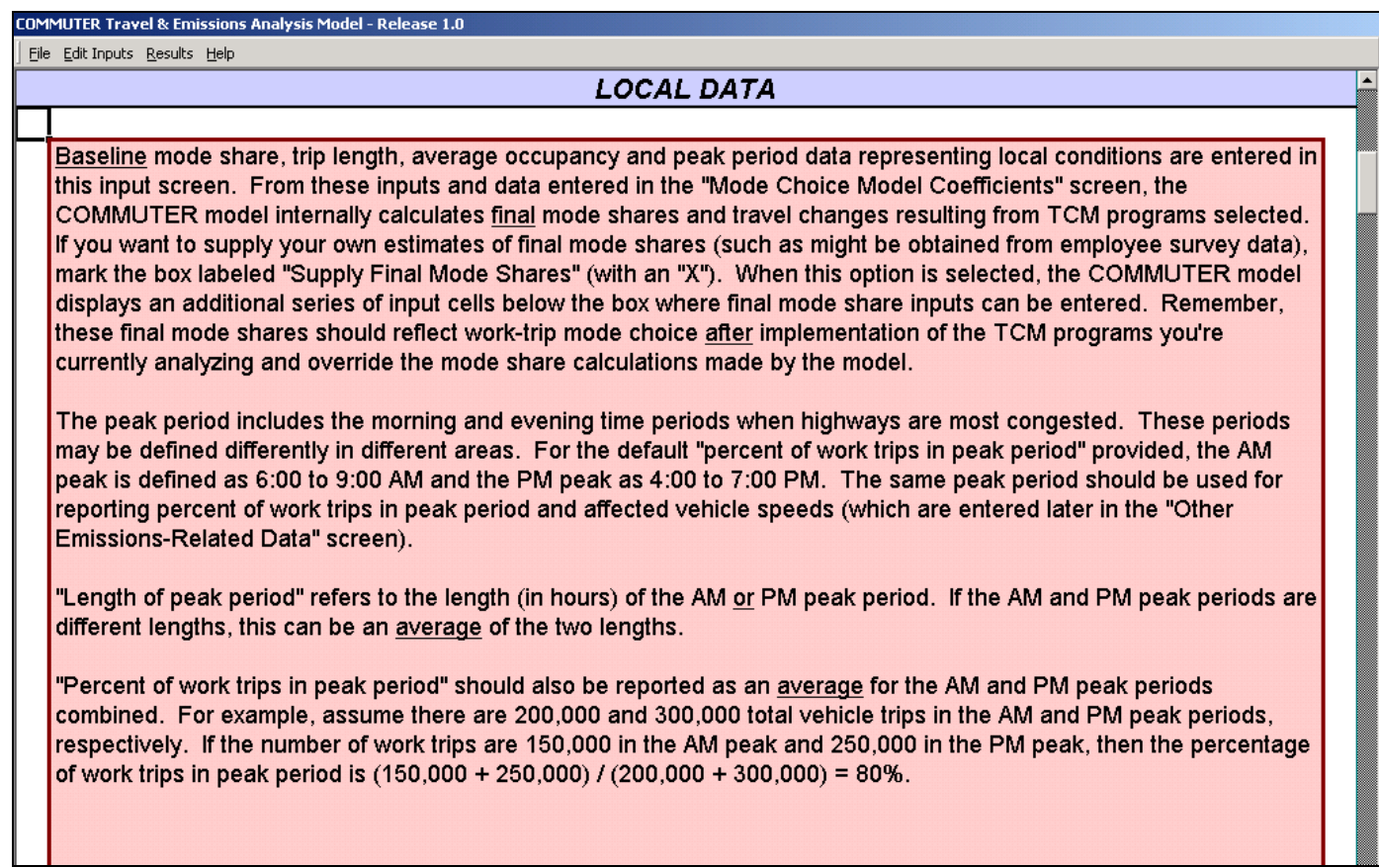

Figure 16. Commuter Model - Local Data Screen (cont.). 


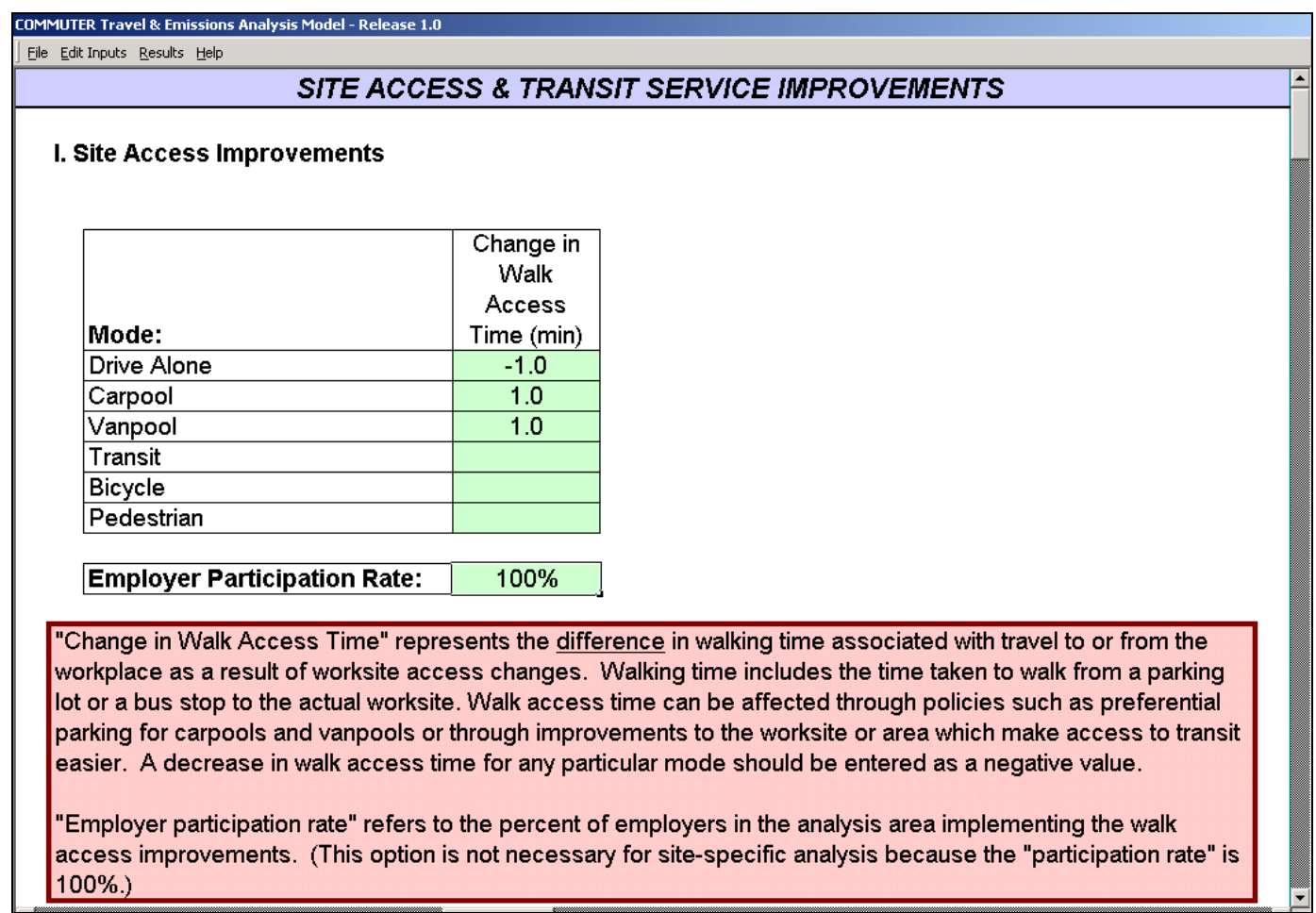

Figure 17. Commuter Model - Site Access and Transit Service Improvements Screen.

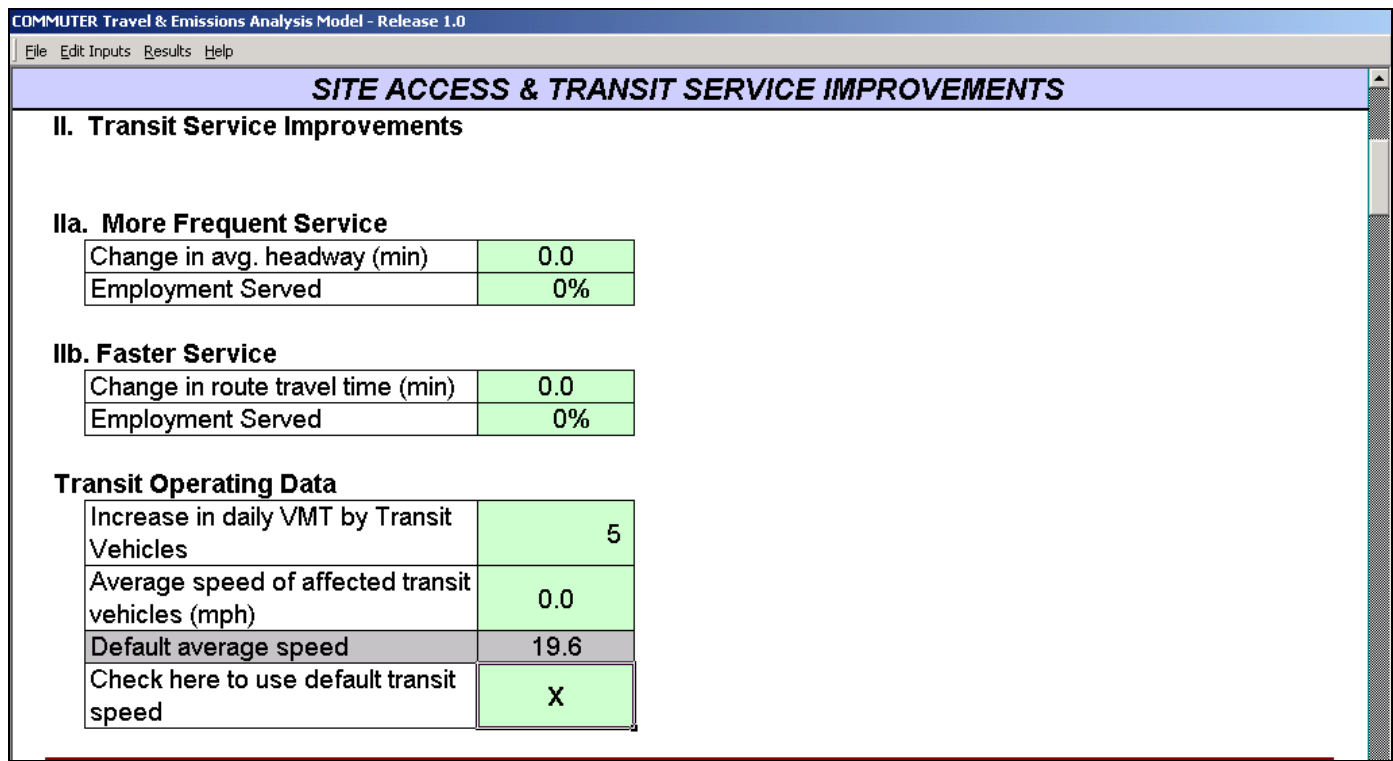

Figure 18. Commuter Model - Site Access and Transit Service Improvements Screen (cont.). 


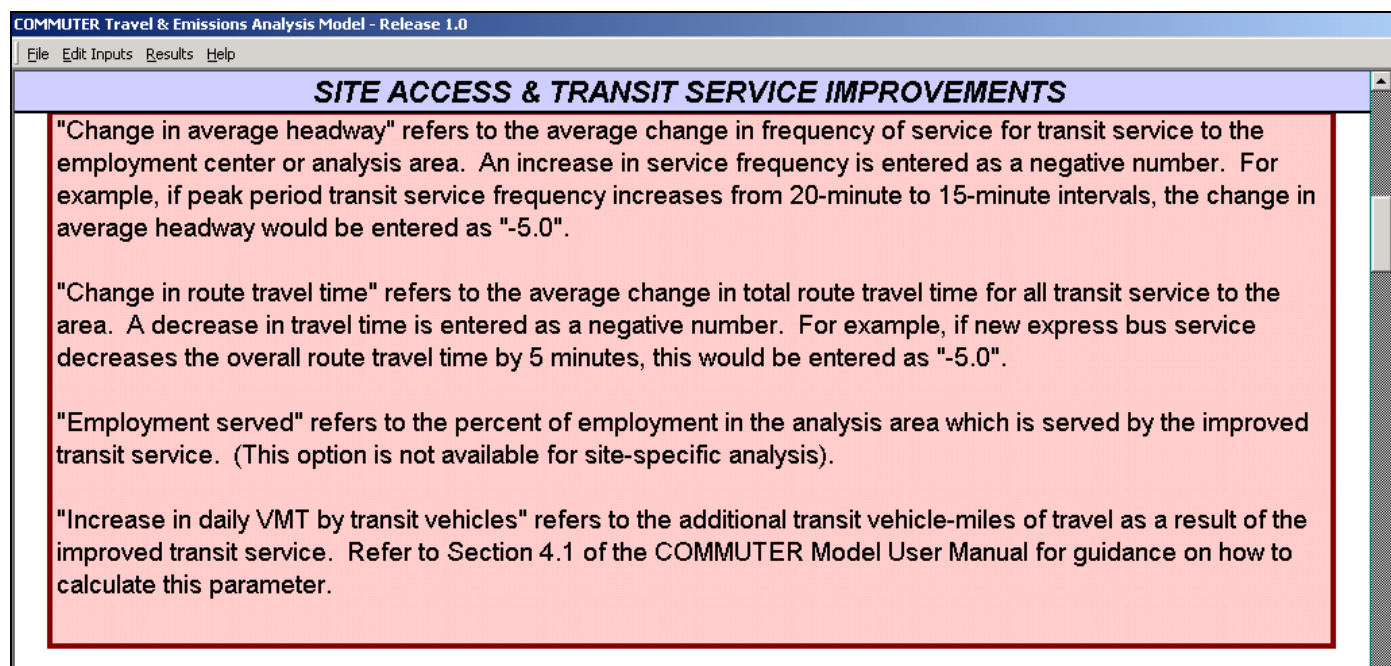

Figure 19. Commuter Model - Site Access and Transit Service Improvements Screen (cont.).

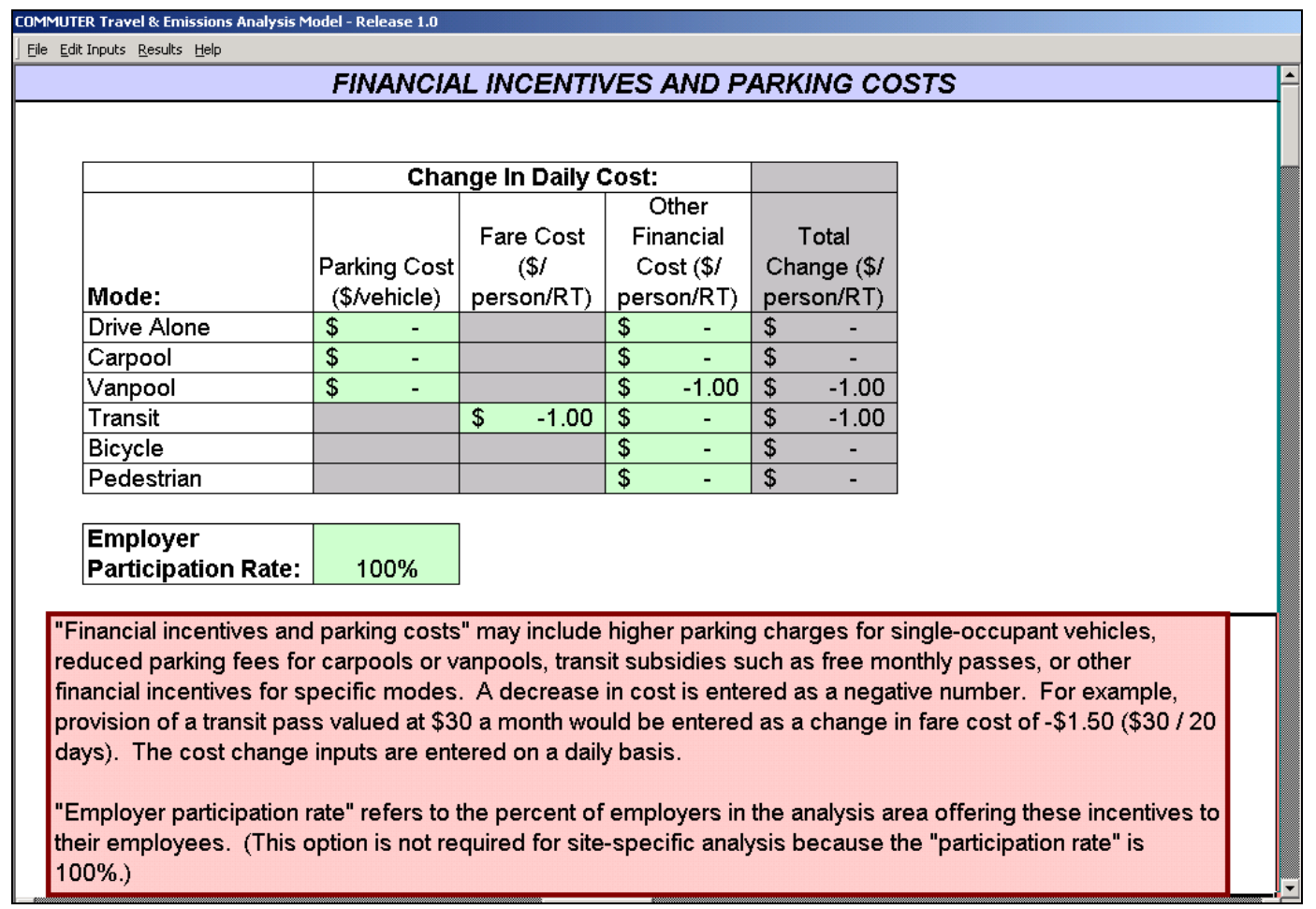

Figure 20. Commuter Model - Financial Incentives and Parking Screen. 


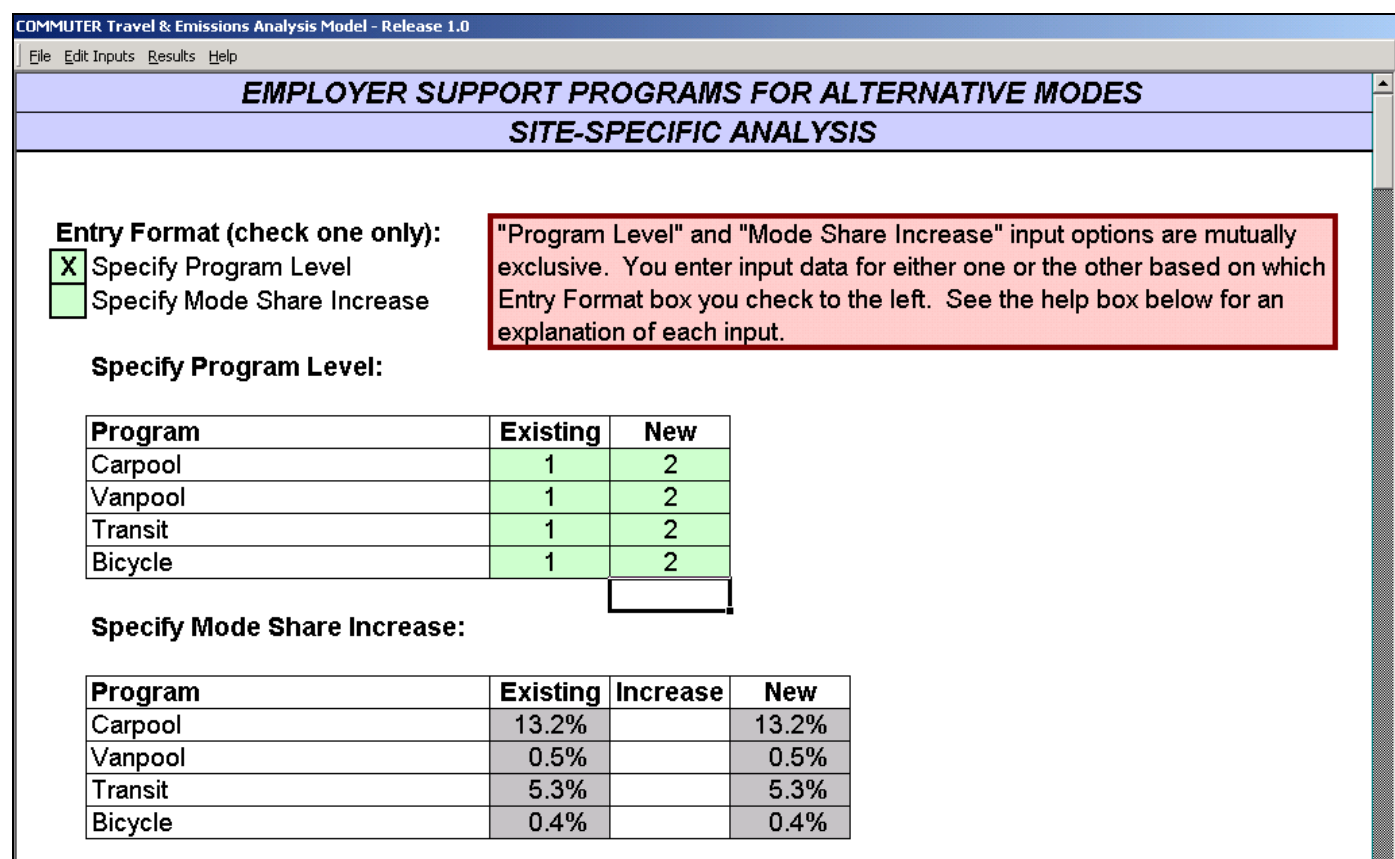

Figure 21. Commuter Model - Employer Support Programs for Alternative Modes - Site Specific Analysis Screen.

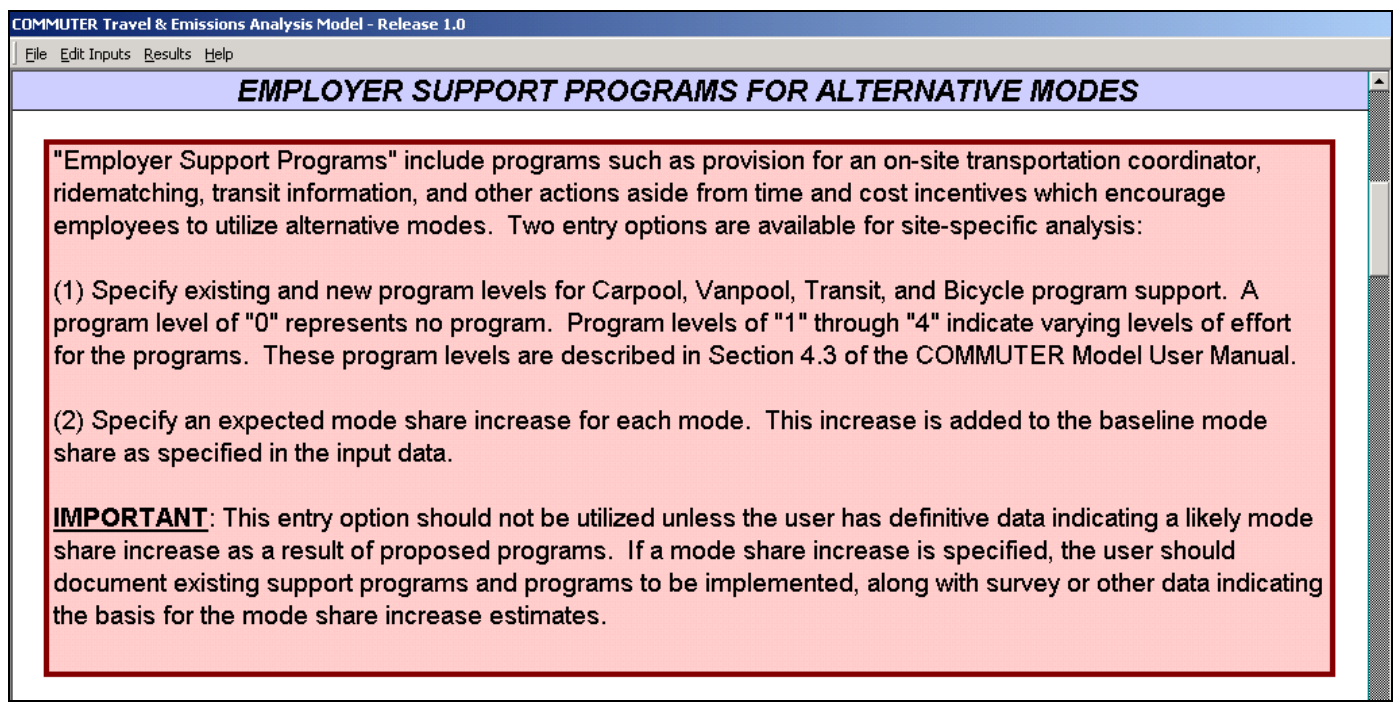

Figure 22. Commuter Model - Employer Support Programs for Alternative Modes - Site Specific Analysis Screen. 


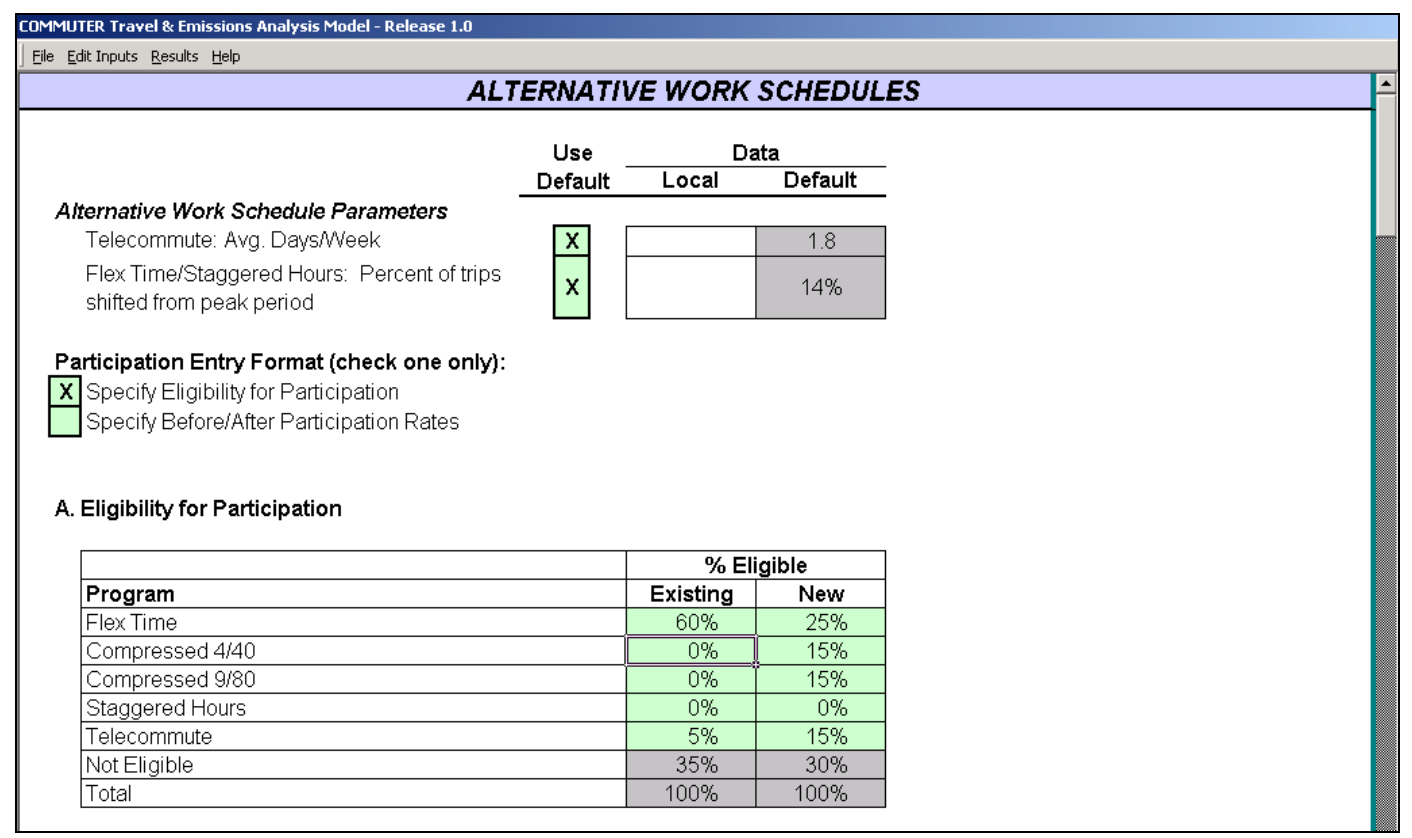

Figure 23. Commuter Model - Alternative Work Schedules Screen.

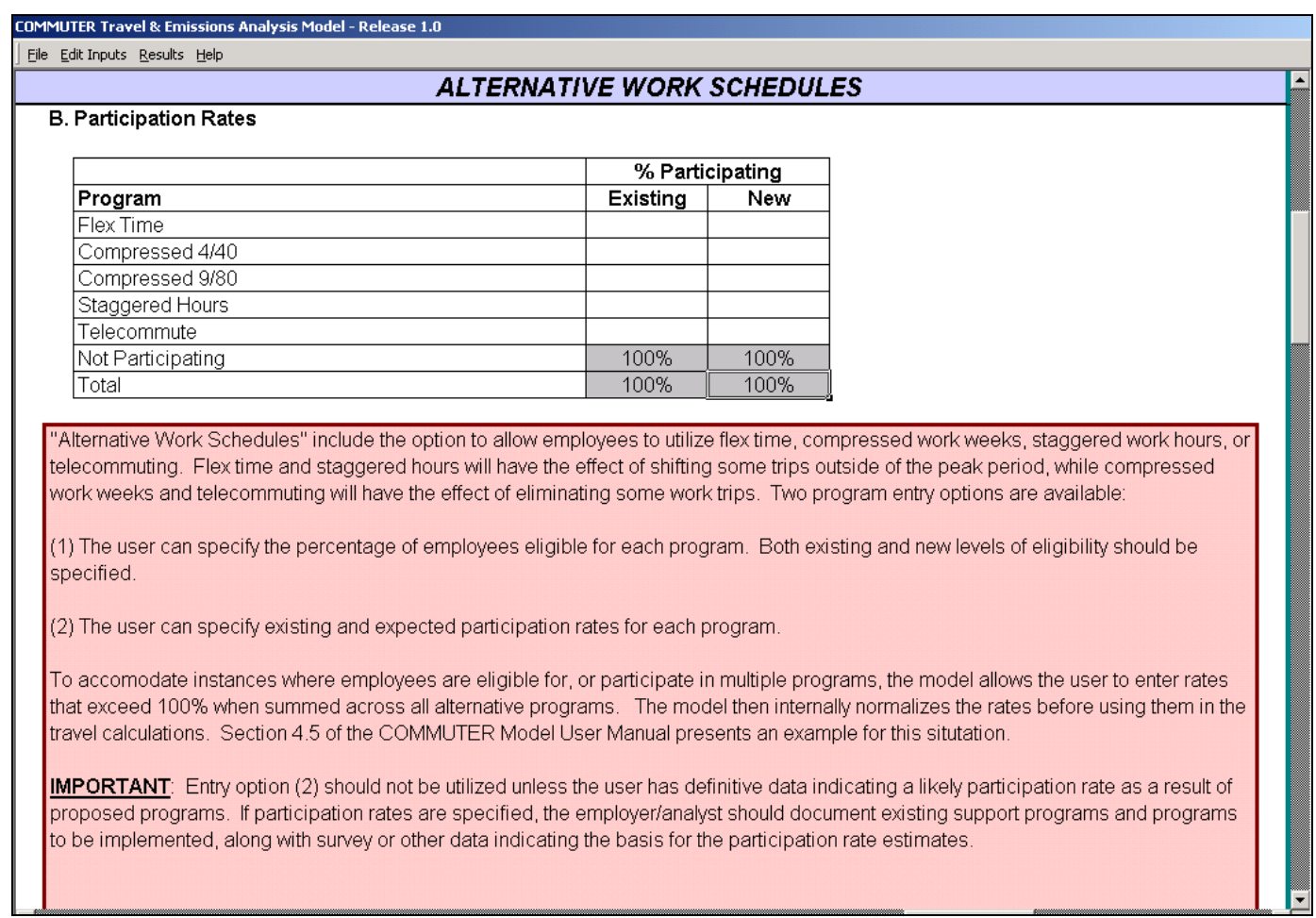

Figure 24. Commuter Model - Alternative Work Schedules Screen. 


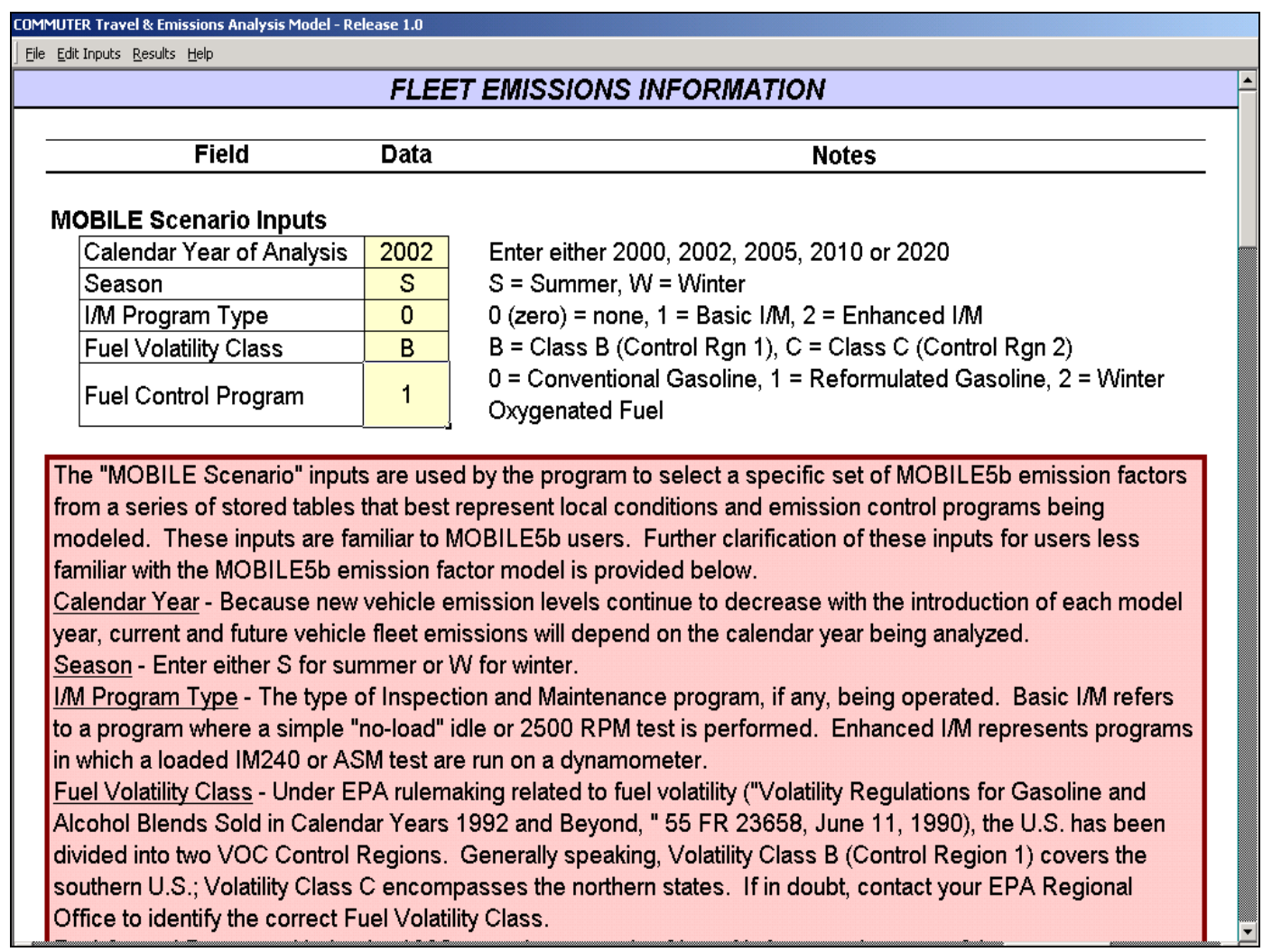

Figure 25. Commuter Model - Fleet Emissions Information Screen.

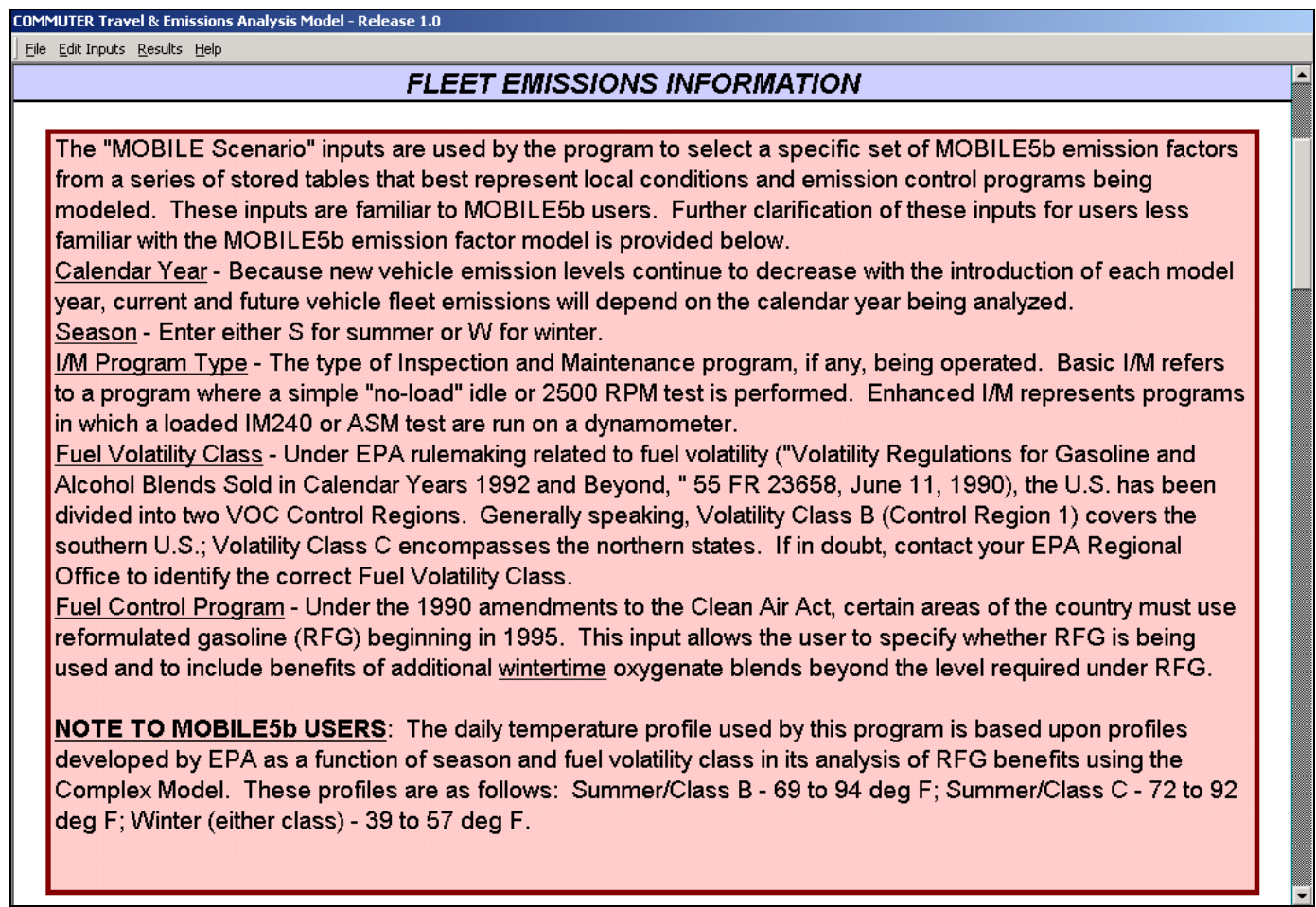

Figure 26. Commuter Model - Fleet Emissions Information Screen (cont.). 


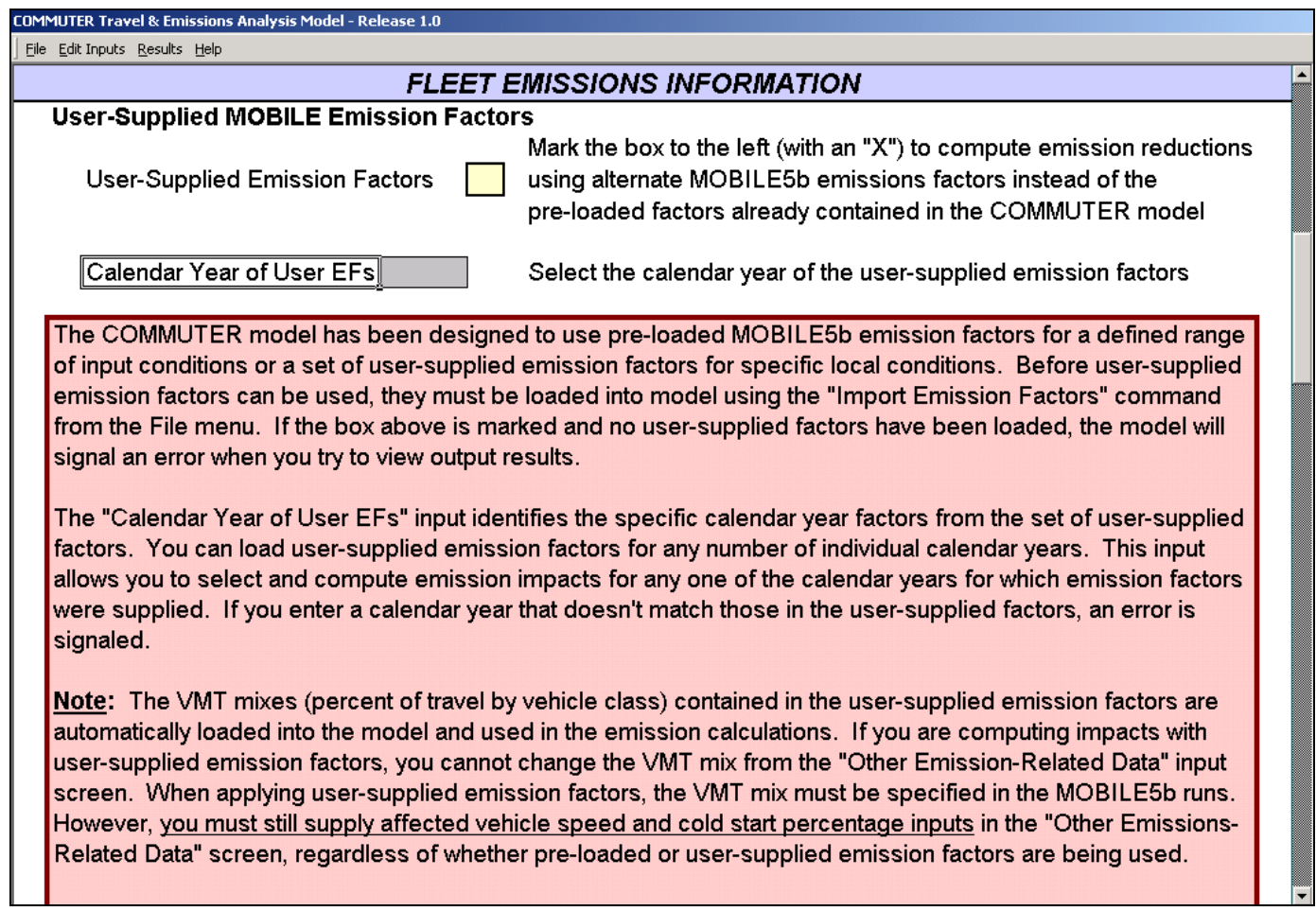

Figure 27. Commuter Model - Fleet Emissions Information Screen (cont.).

\begin{tabular}{|c|c|c|c|c|}
\hline \multicolumn{5}{|c|}{ OTHER EMISSIONS-RELATED DATA } \\
\hline & \multirow{2}{*}{$\begin{array}{c}\text { Use } \\
\text { Default }\end{array}$} & \multicolumn{2}{|c|}{ Data } & \multirow[b]{2}{*}{ Explanatory Notes } \\
\hline & & Local & Default & \\
\hline \multicolumn{4}{|l|}{ Vehicle Fleet VMT Mix } & Percentages of total VMT by vehicle type \\
\hline \multicolumn{2}{|l|}{ LDGV - Light-Duty Gas Vehicles } & & $60.8 \%$ & \\
\hline \multirow{2}{*}{\multicolumn{2}{|c|}{ LDGT1 - Light-Duty Gas Trucks 1}} & & $19.4 \%$ & To 6,000 lbs GWW (gross vehicle weight) \\
\hline \multirow{2}{*}{\multicolumn{2}{|c|}{$\begin{array}{l}\text { LDGT2 - Light-Duty Gas Trucks } 2 \\
\text { HDGV - Heavy-Duty Gas Vehicles }\end{array}$}} & & $8.6 \%$ & From 6,001 to $8,500 \mathrm{lbs}$ GWW \\
\hline & & & $3.1 \%$ & Over $8,500 \mathrm{lbs}$ GWW \\
\hline \multicolumn{2}{|l|}{ LDDV - Light-Duty Diesel Vehicles } & & $0.1 \%$ & \\
\hline \multicolumn{2}{|l|}{ LDDT - Light-Duty Diesel Trucks } & & $0.2 \%$ & To $8,500 \mathrm{lbs}$ GWW \\
\hline \multirow{2}{*}{\multicolumn{2}{|c|}{$\begin{array}{l}\text { HDDV - Heavy-Duty Diesel Trucks } \\
\text { MC - Motorcycles }\end{array}$}} & & $7.2 \%$ & Over $8,500 \mathrm{lbs}$ GWW \\
\hline & & & $0.6 \%$ & \\
\hline \multicolumn{2}{|l|}{ TOTAL (must add to $100 \%$ ) } & $0.0 \%$ & $100.0 \%$ & \\
\hline \multicolumn{4}{|l|}{ Affected Vehicle Speed (mph) } & Average speed (mph) of TCM-affected trips \\
\hline \multirow{2}{*}{\multicolumn{2}{|c|}{$\begin{array}{l}\text { Peak Period Average Speed } \\
\text { Off-Peak Period Average Speed }\end{array}$}} & & 31.8 & \\
\hline & & & 37.1 & \\
\hline \multicolumn{4}{|l|}{ Cold Start Percentages } & Percent of trips that start "cold" \\
\hline \multirow{4}{*}{$\begin{array}{l}\text { Baseline - Peak Period } \\
\text { Baseline - Off-Peak Period } \\
\text { Eliminated Trips - Peak } \\
\text { Eliminated Trips - Off-Peak }\end{array}$} & & & $48.0 \%$ & Peak period trips that start cold \\
\hline & & & $40.0 \%$ & Off-peak period trips that start cold \\
\hline & & & $48.0 \%$ & TCM-eliminated peak trips that start cold \\
\hline & & & $40.0 \%$ & TCM-eliminated off-peak trips that start cold \\
\hline
\end{tabular}

Figure 28. Commuter Model - Other Emissions-Related Data Screen. 


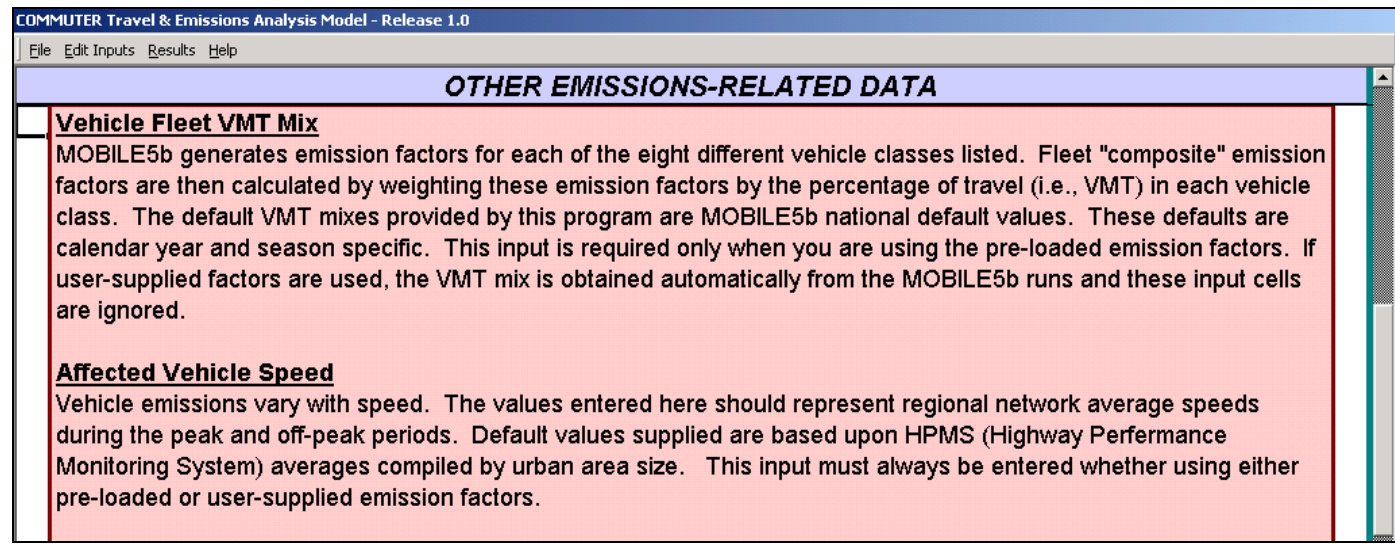

Figure 29. Commuter Model - Other Emissions-Related Data Screen (cont.).

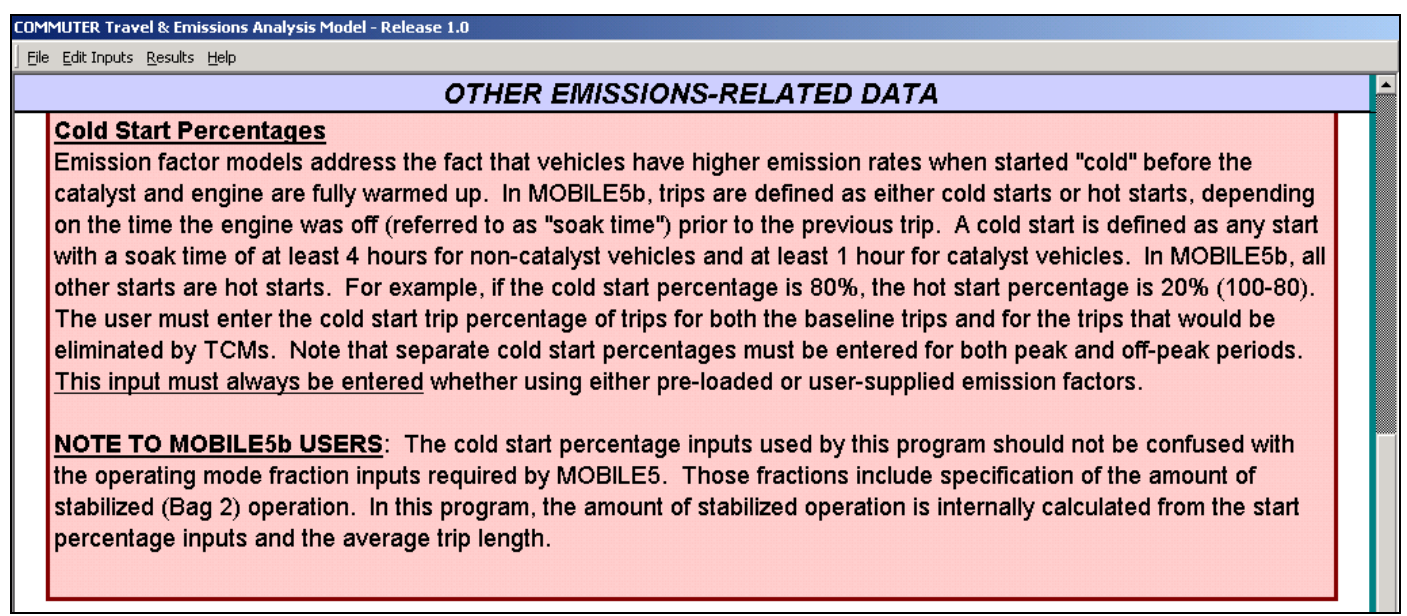

Figure 30. Commuter Model - Other Emissions-Related Data Screen (cont.). 


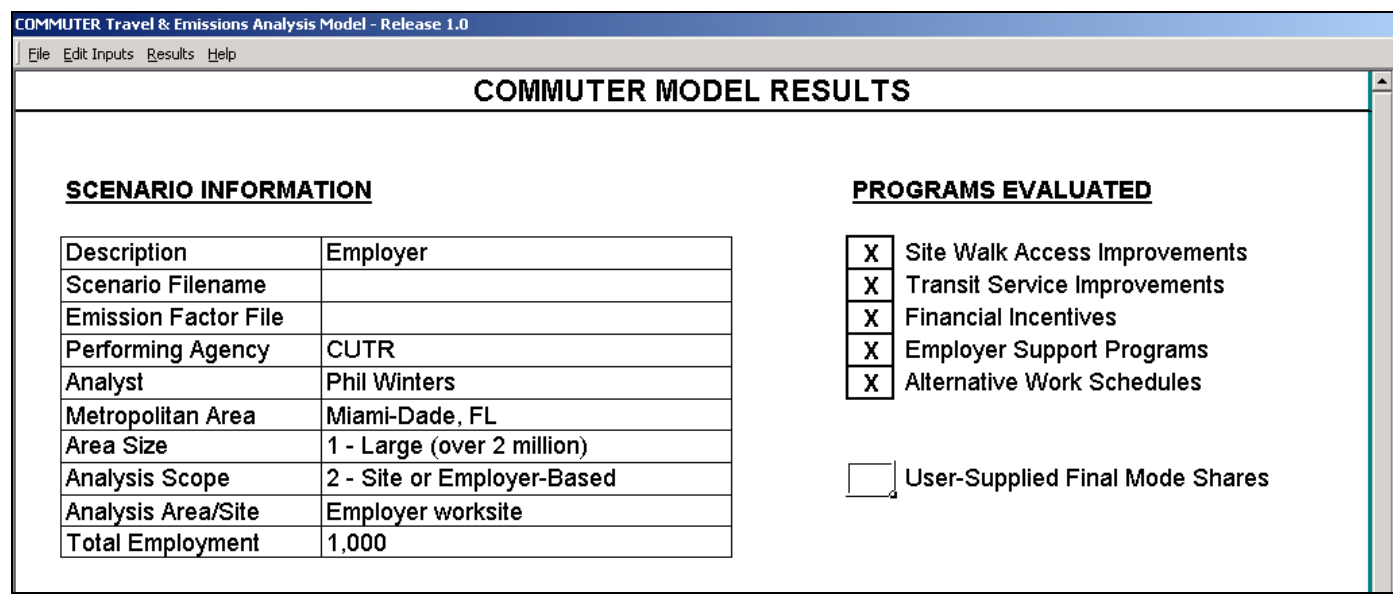

Figure 31. Commuter Model - Results Screen.

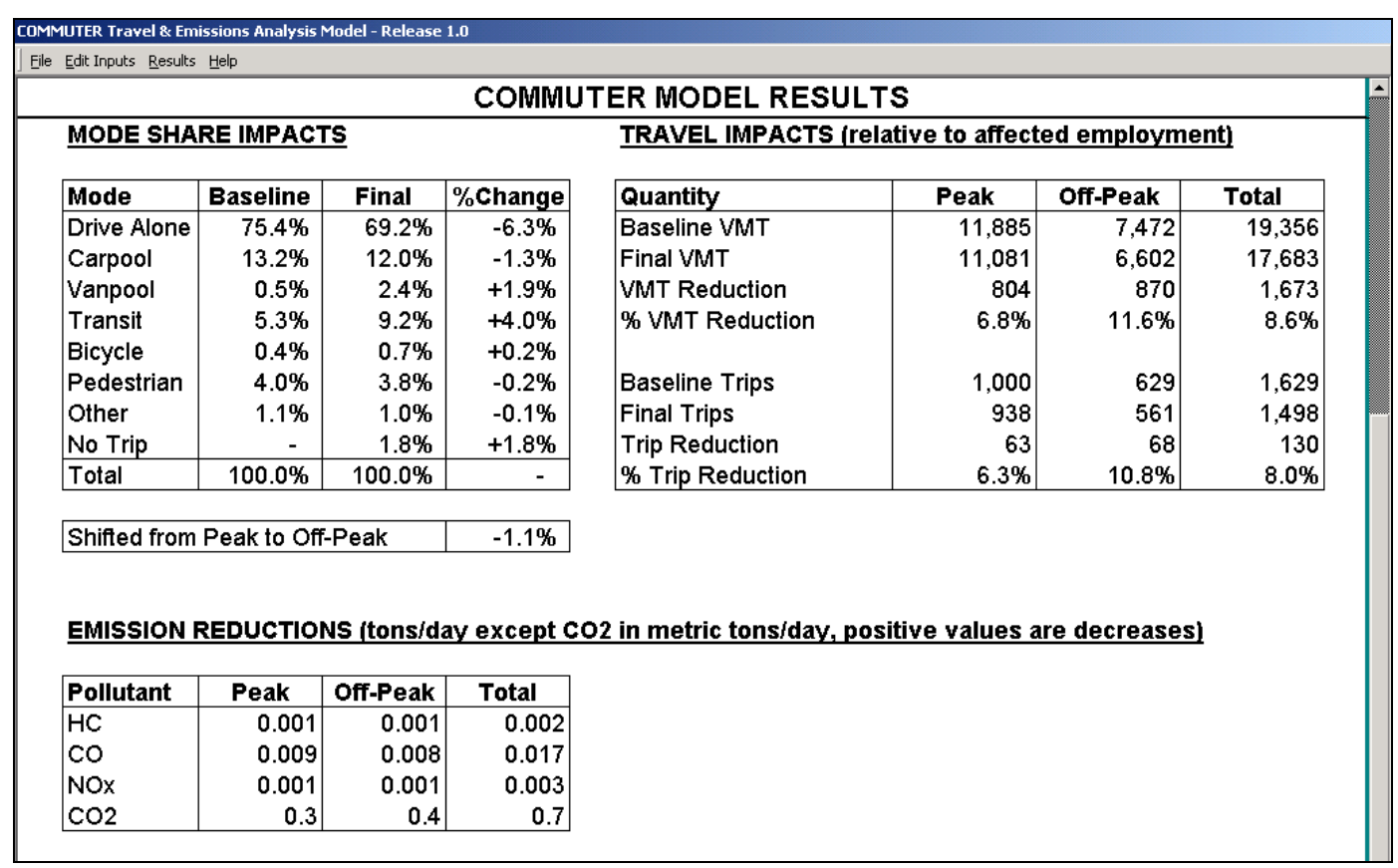

Figure 32. Commuter Model - Results Screen (cont.). 